\title{
LONG-TERM WATER SUPPLY POTENTIAL, GREEN SWAMP AREA, FLORIDA
}

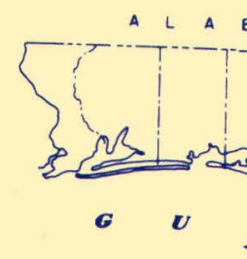

U.S. GEOLOGICAL SURVEY

Water-Resources Investigations 78-99

Prepared in cooperation with the

SOUTHWEST FLORIDA WATER MANAGEMENT DISTRICT 
4. Title and Subtitle

LONG-TERM WATER SUPPLY POTENTIAL, GREEN SWAMP AREA, FLORIDA

7. Author(s)

Grubb, Hayes F. and Rutledge, A. T.

9. Performing Organization Name and Address

U.S. Geological Survey, Water Resources Division

325 John Knox Road, Suite F-240

Tallahassee, Florida 32303

12. Sponsoring Organization Name and Address

U.S. Geological Survey, Water Resources Division

325 John Knox Road, Suite F-240

Tallahassee, Florida 32303

13. Type of Report \& Period Covered
8. Performing Organization Rept. No. USGS/WRI 78-99

10. Project/Task/Work Unit No.

15. Supplementary Notes

Report prepared in cooperation with Southwest Florida Water Management District.

16. Abstracts The Green Swamp is an 870 square-mile area of interspersed swamps and flat uplands located in central Florida about 20 miles west of orlando and about 30 miles northeast of Tampa. Estimates of principal water budget items are (1) inflow, 52.10 inches of rainfall and less than one-half inch of ground-water inflow and (2) outflow, 10 inches of surface runoff, 2 inches of ground-water outflow, and 40 inches of evapotranspiration. The effects of large-scale pumping from the Floridan aquifer were evaluated using a steady-state finite-difference ground-water flow model. The average simulated drawdown in the modeled area was 2 feet for a withdrawal rate of 91 million gallons per day from 6 pumping centers, 4 feet for a withdrawal rate of 183 million gallons per day from 12 pumping centers, and 6 feet for a withdrawal rate of 274 million gallons per day from 18 pumping centers. The 274 million gallons per day is equivalent to the estimated natural ground-water outflow plus about 45 percent of the runoff from the Green Swamp.

17. Key Words and Document Analysis. 17a. Descriptors

Ground-water recharge, Pumping, Simulation Analysis, Confined aquifer, Water Supply, Leakage, Confining bed, Drawdown, Induced infiltration, Unconfined aquifer, Diversion

17b. Identifiers/Open-Ended Terms

Florida, Floridan aquifer, Green Swamp

17c. COSATI Field Group

18. Availability Statement

No restriction on distribution.

\begin{tabular}{|l|l|}
$\begin{array}{l}\text { 19. Security Class (This } \\
\text { Report) } \\
\text { UNCLASSIFIED }\end{array}$ & $\begin{array}{c}\text { 21. No. of Pages } \\
86\end{array}$ \\
\hline $\begin{array}{l}\text { 20. Security Class (This } \\
\text { Page } \\
\text { UNCLASSIFIED }\end{array}$ & 22. Price \\
\hline
\end{tabular}


LONG-TERM WATER SUPPLY POTENTIAL, GREEN SWAMP

AREA, FLORIDA

By Hayes F. Grubb and A. T. Rutledge

U.S. GEOLOGICAL SURVEY

Water Resources Investigations 78-99

Prepared in cooperation with the

SOUTHWEST FLORIDA WATER MANAGEMENT DISTRICT

Ta1lahassee, F1orida

1979 
UNITED STATES DEPARTMENT OF THE INTERIOR

CECIL D. ANDRUS, Secretary

GEOLOGICAL SURVEY

H. William Menard, Director

For additional information write to:

U.S. Geologica1 Survey

325 John Knox Road

Suite $\mathrm{F}-240$

Tallahassee, Florida 32303 
Abstract--

Introduction--_- 2

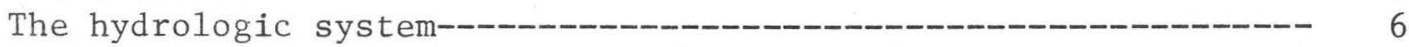

Inflow--- 6

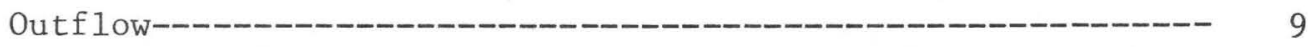

Streamflow---_--_-_-- 9

Ground water-_- 17

Evapotranspiration-_-_-_-_-_-_-_-_-_-_-_-_ 21

Suitability of outflows as source of water supply--------- 21

Streamflow-_- 25

Ground water-- 26

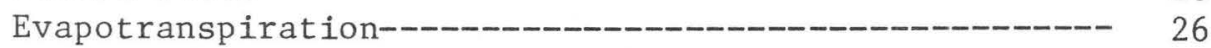

Potential of ground water for water supply--.---_--- 28

Ground-water system---_-_-_-_- 28

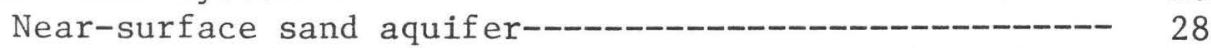

Upper confining beds--_-_- 31

Floridan aquifer-- 35

Digital prototype----- 39

Floridan aquifer-- 39

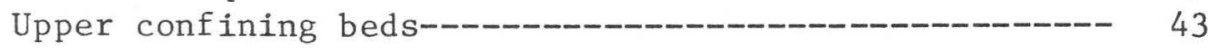

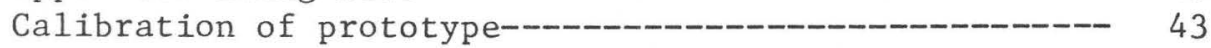

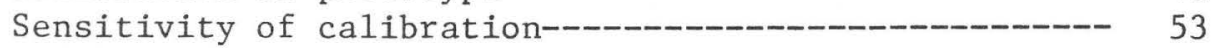

Potentiometric surface of sand aquifer-------- 53

Floridan aquifer transmissivity----_----- 53

Confining bed hydraulic conductivity-_-_- 53

Significance of calibration sensitivity--_----- 53

Effects of large-scale withdrawals-_-_-_-_ 57

Floridan aquifer--_- 57

Six pumping centers--_- 58

Twelve pumping centers--_-_-_- 58

Eighteen pumping centers--- 62

Eighteen pumping centers and conservation pool in flood detention area--_-_- 62

Uniform changes in hydraulic coefficients------- 67

Boundary evaluation--_-_-_-- 67

Sand aquifer-_- 69

Runoff and evapotranspiration-_-_- 72

Summary of conclusions- 73

References-- 74 


\section{ILLUSTRATIONS}

Figure

1. Map showing location of the Green Swamp area---------

2. Map of Green Swamp area showing location of the flood detention area proposed by Southwest Florida Water Management District, core holes, observations we1ls, and stream-gaging stations-

3. Graph showing annual precipitation for 1931-76----------

4. Graph showing long-term average monthly precipitation, 1931-76-

5. Graph showing annual average streamflow for Big Creek

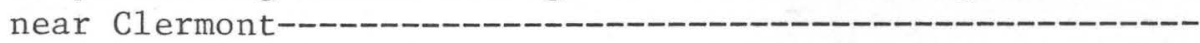

6. Graph showing annual average streamflow of Withlacoochee

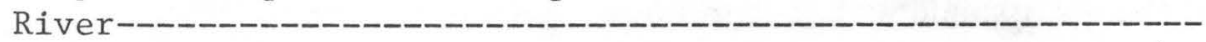

7. Graph showing long-term average monthly runoff at A, Big Creek near Clermont; B, Withlacoochee River near Eva; C, Withlacoochee River near Cumpressco; and D, Little

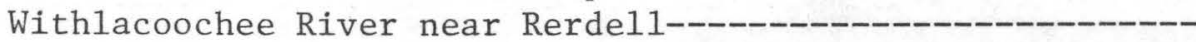

(1)

Graph showing relation of annual average streamflow of the Withlacoochee River at Trilby to the annual average streamflow of the Withlacoochee River near Cumpressco,

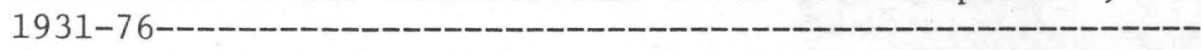

9. Map showing potentiometric surface of the Floridan aquifer, May 1977

10. Graph showing average month-end water levels in the

11. Graph showing month-end water levels in the Floridan aquifer 1960-77--------------

12. Graph showing monthly potential evapotranspiration estimated by the Thornthwaite method, 1931-76----_--- 24

13. Map showing thickness of the near-surface sand aquifer---- 30

14. Graph showing long-term average month-end water levels in the near-surface sand aquifer-- 32

15. Map showing estimated potentiometric surface of the nearsurface sand aquifer, May 1977-- 33

16. Map showing thickness of the confining beds overlying Floridan aquifer----_-- 34

17. Graph showing drawdown in near-surface sand aquifer and in Floridan aquifer due to pumping from the Floridan aquifer at 1,040 gallons per minute (observation we11s about 62 feet from pumping we11)-_-

18. Map showing finite-difference grid used for the digital ground-water flow model

19. Sections showing potentiometric surface of the sand aquifer, the potentiometric surface of the Floridan aquifer, and the flow in and out of the modeled aquifer--- 


\section{ILLUSTRATIONS - Continued}

Figure

Page

20. Map showing initial estimates of transmissivity of the Floridan aquifer--------------

21. Map showing upper confining bed thickness used in the

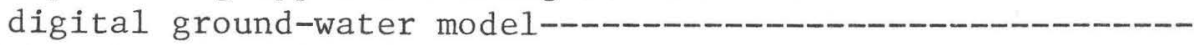

22. Map showing initial estimate of upper confining bed vertical hydraulic conductivity used in the digital

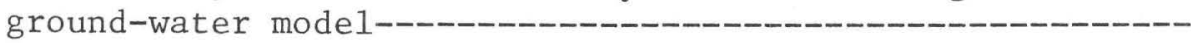

23. Graph showing average error per node for various calibration runs of the digital model. Hydrologic parameter adjustments made before individual model runs

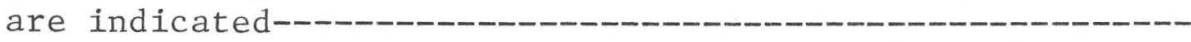

24. Map showing the May 1977 potentiometric surface of the Floridan aquifei compared to the potentiometric surface from the calibrated model-_-_-_-

25. Graph showing comparison of the potentiometric surface of the Floridan aquifer in May 1977 to that generated by

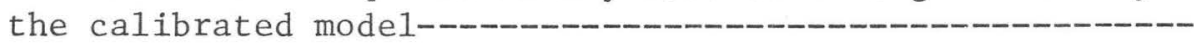

26. Map showing distribution of Floridan aquifer transmissivity in the calibrated model----------------

27. Map showing distribution of upper confining bed vertical hydraulic conductivity in the calibrated model------------

28. Graph showing the effects of a 1 percent increase and a 1 percent decrease in the altitude of the potentiometric surface of the sand aquifer on the calibrated potentiometric surface of the Floridan aquifer------------

29. Graph showing the effects of a 50 percent increase and a 50 percent decrease in aquifer transmissivity and upper confining bed hydraulic conductivity on the calibrated potentiometric surface of the Floridan aquifer

30. Map showing the simulated effects of pumping about 91 million gallons per day on the potentiometric surface of the Floridan aquifer--_-

31. Map showing simulated effects of pumping about 183 million gallons per day on the potentiometric surface of the Floridan aquifer--_--

32. Map showing simulated effects of pumping about 274 million gallons per day on the potentiometric surface of the Floridan aquifer--

33. Graphs showing simulated potentiometric surfaces of the Floridan aquifer: (a) with 18 pumping centers, (b) without pumpage--

34. Map showing model nodes that exhibited maximum simulated recharge (20 inches per year) with pumpage of 274 million gallons per day-------- 


\section{ILLUSTRATIONS - Continued}

Figure

35. Map showing simulated effects of pumping about

274 million gallons per day on the potentiometric surface with a conservation pool in the flood

detention area-----------

36. Graph showing simulated potentiometric surface of the Floridan aquifer showing sensitivity of the prototype to a uniform increase and decrease in aquifer transmissivity and vertical hydraulic conductivity of the upper confining bed

37. Graph showing simulated time required to dewater the sand aquifer for various values of confining bed hydraulic conductivity with a simulated head condition of maximum vertical gradient and no recharge, assuming a specific yield of 10 percent for the sand aquifer-------

TABLES

Table

1. Stream gaging stations used for calculation of runoff from the Green Swamp area--

2. Summary of stream flow regression analysis used to extend short-term records to the $1931-76$ period of record for Withlacoochee River at Trilby-

3. Long-term average annual runoff from four basins in the Green Swamp area, 1931-76-_-

4. Drawdown in the near-surface sand aquifer after pumping the Floridan aquifer at an average rate of 1,040 gallons per minute-state inflow and outflow for various conditions simulated by the digital model 


\section{Conversion Factors}

For use of those readers who may prefer to use metric units rather than U.S. customary units, the conversion factors for the terms used in this report are listed below:

Multiply U.S. customary units

By To obtain metric units

\begin{tabular}{|c|c|c|}
\hline ft (foot) & 0.3048 & m (meter) \\
\hline $\mathrm{ft} / \mathrm{d}$ (foot per day) & 0.3048 & m/d (meter per day) \\
\hline $\mathrm{ft}^{2} / \mathrm{d}$ (foot squared per day) & 0.0929 & $\begin{array}{l}\mathrm{m}^{2} \mathrm{~d} \text { (meter squared per } \\
\text { day) }\end{array}$ \\
\hline $\mathrm{ft}^{3} / \mathrm{s}$ (cubic foot per second) & $2.832 \times 10^{-2}$ & $\begin{array}{l}\mathrm{m}^{3} / \mathrm{s} \text { (cubic meter per } \\
\text { second) }\end{array}$ \\
\hline gal/min (gallon per minute) & $6.309 \times 10^{-2}$ & L/s (liter per second) \\
\hline $\begin{array}{l}\text { Mgal/d (million gallon per } \\
\text { day) }\end{array}$ & 0.0438 & $\begin{array}{l}\mathrm{m}^{3} / \mathrm{s} \text { (cubic meter per } \\
\text { second) }\end{array}$ \\
\hline in. (inch) & $2.540 \times 10^{+1}$ & $\mathrm{~mm}$ (millimeter) \\
\hline in./yr (inch per year) & $2.540 \times 10^{+} 1$ & $\begin{array}{l}\text { mm/yr (millimeter per } \\
\text { year) }\end{array}$ \\
\hline mi (mile) & 1.609 & $\mathrm{~km}$ (kilometer) \\
\hline $\mathrm{mi}^{2}$ (square mile) & 2.590 & $\mathrm{~km}^{2}$ (square kilometer) \\
\hline
\end{tabular}



LONG-TERM WATER SUPPLY POTENTIAL, GREEN SWAMP AREA, FLORIDA

By

Hayes F. Grubb and A. T. Rutledge

ABSTRACT

The Green Swamp is an 870 square-mile area of interspersed swams and flat uplands located in central Florida about 20 miles west of Orlando and about 30 miles northeast of Tampa. The potentiometric high of the Floridan aquifer (the principal source of ground water in central Florida) is in the southeast quarter of the Green Swamp area.

The hydrologic system was analyzed relative to its long-term water-supply potential. Estimates of principal water budget items are (1) inflow, 52.10 inches of rainfall and less than one-half inch of ground-water inflow and (2) outflow, 10 inches of surface runoff, 2 inches of ground-water outflow, and 40 inches of evapotranspiration.

An evaluation of the outflows as sources of water supply indicates some ground-water outflow and surface runoff can be diverted by pumping from the Floridan aquifer.

The effects of large-scale pumping from the Floridan aquifer were evaluated using a steady-state finite-difference ground-water flow model. The average simulated drawdown in the modeled area was 2 feet for a withdrawal rate of 91 million gallons per day from 6 pumping centers, 4 feet for a withdrawal rate of 183 million gallons per day from 12 pumping centers, and 6 feet for a withdrawal rate of 274 million gallons per day from 18 pumping centers. The 274 million gallons per day is equivalent to the estimated natural ground-water outflow plus about 45 percent of the runoff from the Swamp. The relative percentages of ground-water diversion and runoff diversion are dependent upon the quantity and distribution of withdrawal. 


\section{INTRODUCTION}

The Green Swamp area is in central Florida about $20 \mathrm{mi}$ west of Orlando and about $30 \mathrm{mi}$ northeast of Tampa (fig. 1). The maximum dimensions of this irregularly shaped area are about $30 \mathrm{mi}$ in an eastwest direction and about $35 \mathrm{mi}$ in a north-south direction. The area was first delineated by Pride and others (1961, p. 15) and covers about $870 \mathrm{mi}^{2}$.

The Green Swamp is a series of swamps, interspersed with slightly higher flat uplands, and bordered by sand ridges on the east, south and west. The altitude of swamps of $1 \mathrm{mi}^{2}$ or greater ranges from about $130 \mathrm{ft}$ above mean sea level near Lake Lowery in the southeast to about $65 \mathrm{ft}$ above mean sea level near the Withlacoochee River in the northwest. Altitudes of 175 to $250 \mathrm{ft}$ above mean sea level are common along the crest of the ridges bordering the area.

The potentiometric high of the Floridan aquifer in central Florida is in the southeast quarter of the Green Swamp area. This feature was mapped as early as 1934 by Stringfield (1936, plate 12 and p. 148), who described it as one of the most conspicuous features on the potentiometric surface in central Florida.

Increased use of ground water since the early $1960^{\prime} \mathrm{s}$ in such nearby areas as the Middle Gulf area on the west (Cherry and others, 1970) and the spread of urban development southwest of Orlando toward the Green Swamp have focused attention on the long-term water supply potential of this sparsely populated area.

Recognizing the increasing demand for freshwater in southwest Florida and the largely untapped ground-water resource in the Green Swamp area, the Southwest Florida Water Management District and the U.S. Geological Survey agreed to evaluate the long-term water supply potential of this area. An appraisal of the hydrologic significance of the Green Swamp was made in the early 1960's (Pride and others, 1966). Some additional hydrologic information was presented in countywide ground-water and hydrologic reports of Polk and Lake Counties (Stewart, 1966, and Knochenmus and Hughes, 1976). However, these reports provide only general information on the unconsolidated near-surface sediments in the Green Swamp.

Before an evaluation of the water supply potential could be made, more detailed information was needed about the thickness and hydraulic characteristics of the near-surface unconsolidated sediments. These sediments overlie the Floridan aquifer which is the principal source of ground water in the area. Thus, as part of this cooperative study, extensive core drilling was done throughout the area. The unconsolidated sediments were cored from land surface to the top of the Floridan aquifer. Samples of clay and clayey sands were selected for laboratory determination of vertical hydraulic conductivity. Detailed lithologic 


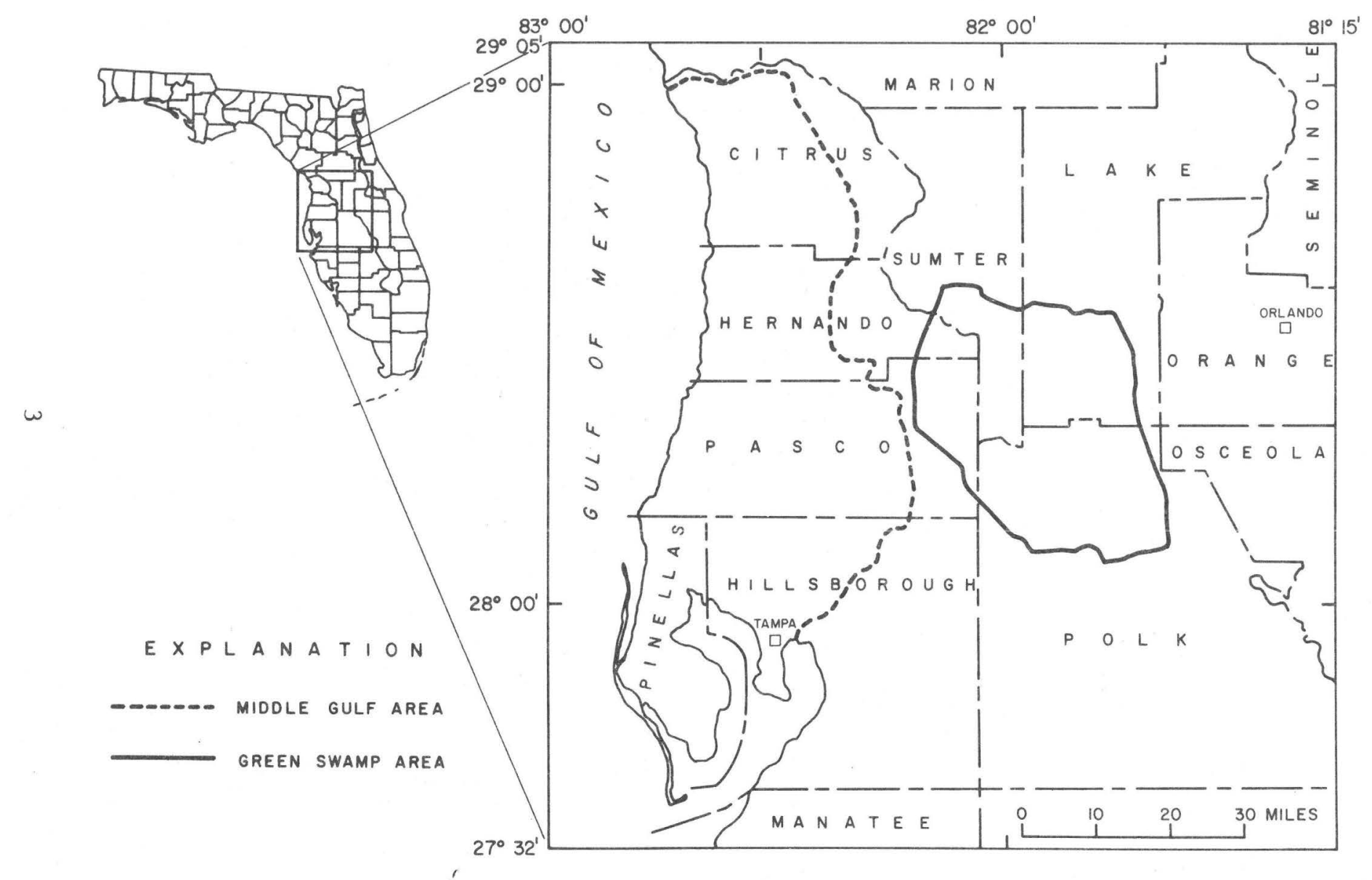

Figure 1.-- Location of the Creen Swamp area 
descriptions and geophysical logs for about 5,500 ft of core from 74 core holes were documented in a report by Grubb and others (1978). Maps of sand thickness, clay thickness, and relative vertical hydraulic conductivity of the upper confining beds have been prepared for about 70 percent of the area (Grubb, 1977).

The most intense core drilling was in an area of about $80 \mathrm{mi}^{2}$ in the west-central part of the Green Swamp (fig. 2) where the Floridan aquifer is at or near land surface. This area has been proposed for use as a flood detention area by the Southwest Florida Water Management District. Data related to the hydrogeologic characteristics of the upper 10 to $50 \mathrm{ft}$ of residuum and unconsolidated coastal plain sediments in this area were compiled as a series of seven maps by Rutledge and Grubb (1978).

Analysis of the cores indicated a high degree of variability in the near-surface unconsolidated sediments. The clay beds are discontinuous and vary greatly in thickness over distances of as little as 1 to 2 miles. In some areas the clay beds are absent and the sand aquifer acts as the upper confining bed of the Floridan aquifer. An aquifer test was conducted to obtain a field estimate of the vertical hydraulic conductivity of the upper confining bed and to provide a basis for evaluating the laboratory determined vertical hydraulic conductivity data relative to actual pumping conditions. The details and results of the aquifer test analysis are given by Grubb (written commun. 1978).

The evaluation of the long-term water supply potential reported herein uses the latest acquired data as well as data developed prior to this study. The evaluation presented is for a level of development which appears practical by using technology commonly applied in this part of Florida and which approaches the maximum capability of the system on a long-term sustained basis. However, in view of inherent uncertainties associated with much of the input data for this analysis, the absolute maximum capability of the system is not well defined. Therefore, the sensitivity of results to uniform increases or decreases in some key parameters is also presented to help the user judge the reliability of this analysis.

There are no known water-quality problems in the Green Swamp area which would curtail use of the water for municipal, agricultural or most industrial supplies (Pride and others, 1966, p. 87, and Knochenmus and Hughes, 1976, p. 75). The water-resource development considered in this report is not expected to cause any significant change in water quality. Therefore, water quality is not considered further in the evaluation of the water supply potential of the area.

It is not the intent of this report to evaluate the desirability of any specific water-resource development scheme. 


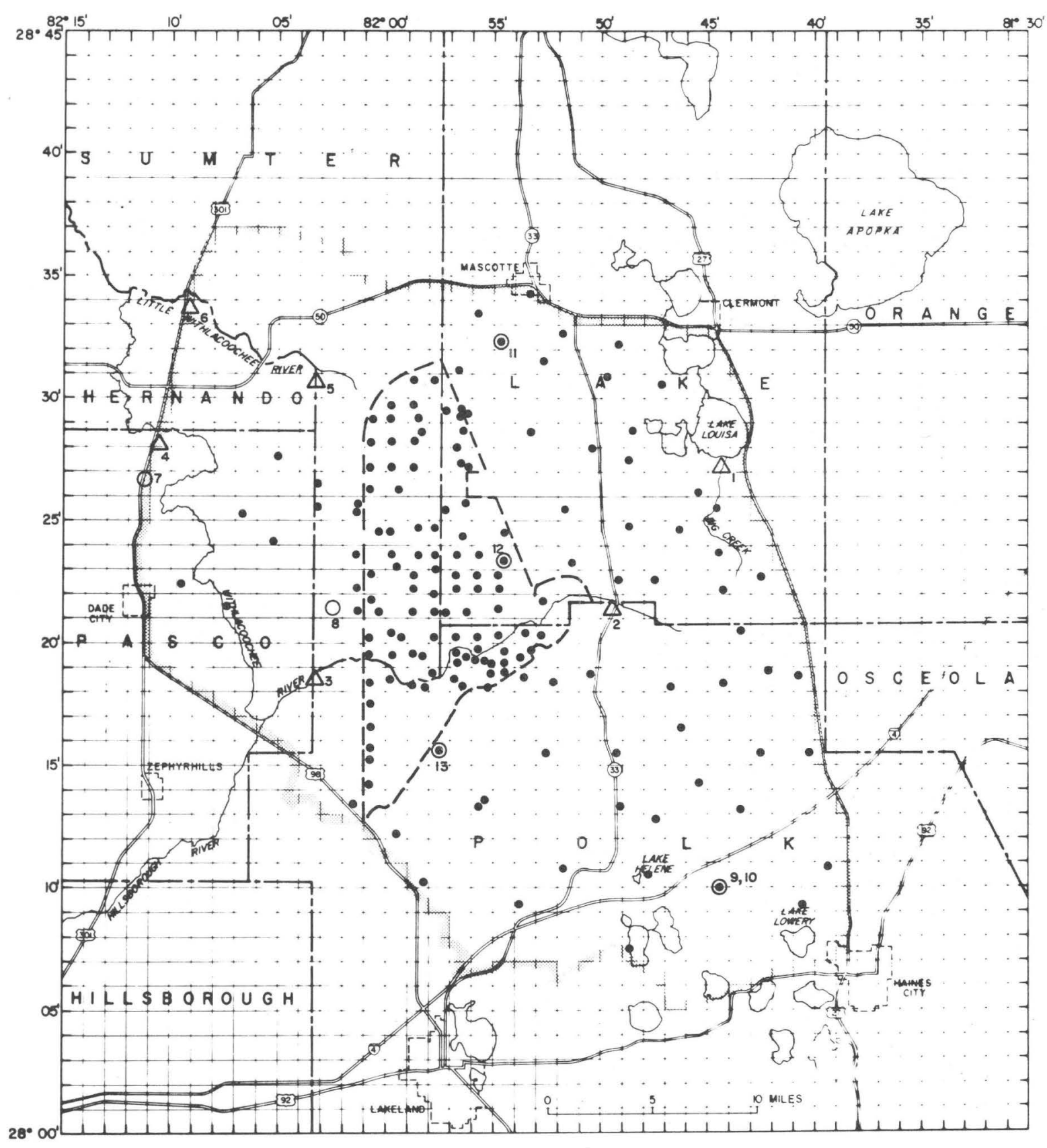

EXPLANATION

$\begin{array}{lll}\text { BOUNDARY OF GREEN } & - \text { CORE HOLE } & \triangle \text { STREAM-GAGING STATION } \\ \text { SWAMP AREA } & 3 \text { HYDROLOGIC SITE } & \text { O OBSERVATION WELL WITH } \\ - \text { INDEX NUMBER } & \text { RECORDER } \\ \text { PROOD DETENTION AREA } & & \\ \text { FLORIDA WATER MANAGE- } & & \\ \text { MENT DISTRICT } & \end{array}$

Figure 2.-Green Swamp area showing, 1)cation of the flond detent ion area prop.used hy Southwest Florida Water Manctient District, core.. ohsivat inns wel.1s, and stream-gaging stations 
Any water artificially pumped from the Green Swamp must have a source. In the long run, pumping must be balanced by an increase in the amount of water entering the area, or by a decrease in water leaving it.

The long-term observed or estimated value of each item of inflow and outflow is presented with the known or estimated variation from the steady flow condition on either an annual or monthly basis. A rigorous analysis of variation from the steady condition is beyond the scope of this study, but such will become increasingly important if development occurs. An increase in the accuracy of defining the maximum capacity of the system should be possible as the level of water-resource development increases if hydrologic data are obtained to relate causes to effects.

\section{Inflow}

The primary source of water to the Green Swamp is rainfall. The long-term average annual rainfall for the Green Swamp is 52.10 in. for 1931-76. This average was computed by the Theissen method using the same long-term National Weather Service stations used by Pride and others (1966, p. 23). The average value for 1931-76 is about 0.6 in. less than the average for 1931-61 owing to the occurrence of the highest 6 years of rainfall in the earlier period (1931-61) and several years of below average rainfall in the latter period (1962-76). The annual precipitation has been less than the long-term average in 9 of the last 14 years (fig. 3). Since 1961 only 1 year (1969) has had more than 60 in. of rainfall. Pride and others (1966, p. 24) noted that the Green Swamp receives about twice as much rainfall during an extremely wet year as it receives in an extremely dry year. The wettest and driest years on record are 1959 (70.9 in.) and 1961 (34.7 in.).

Seasonal variation in rainfall in the Green Swamp is more pronounced than the annual variation. During 1931-76 (fig. 4), the wettest month (July) had over four times the rainfall of the driest month (November). The 4 months in which precipitation exceeds 4 in. account for almost 60 percent of the annual total.

The only known source of inflow to the Green Swamp area other than rainfall is a relatively small quantity of ground-water inflow (less than 1 percent of rainfall) in the vicinity of Dade City (fig. 2). Prior to the development of ground water in the Dade City area, ground water apparently discharged to the Withlacoochee River and associated swamps in the vicinity of the west boundary of the Green Swamp area. An unknown quantity of this ground-water discharge crossed the boundary of the area before reaching the river. Now, the water which flows from the west across the boundary of the area is discharged by pumping wells. 


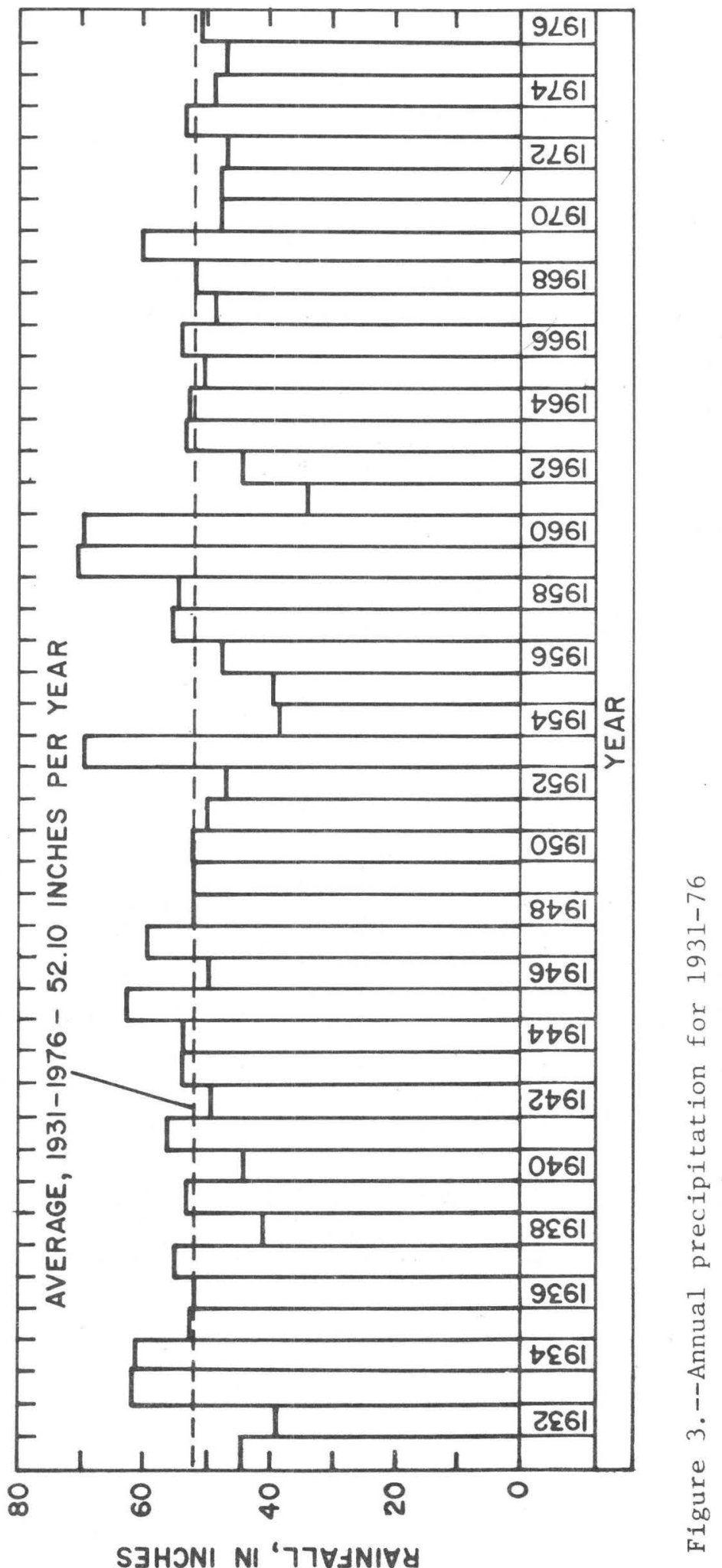




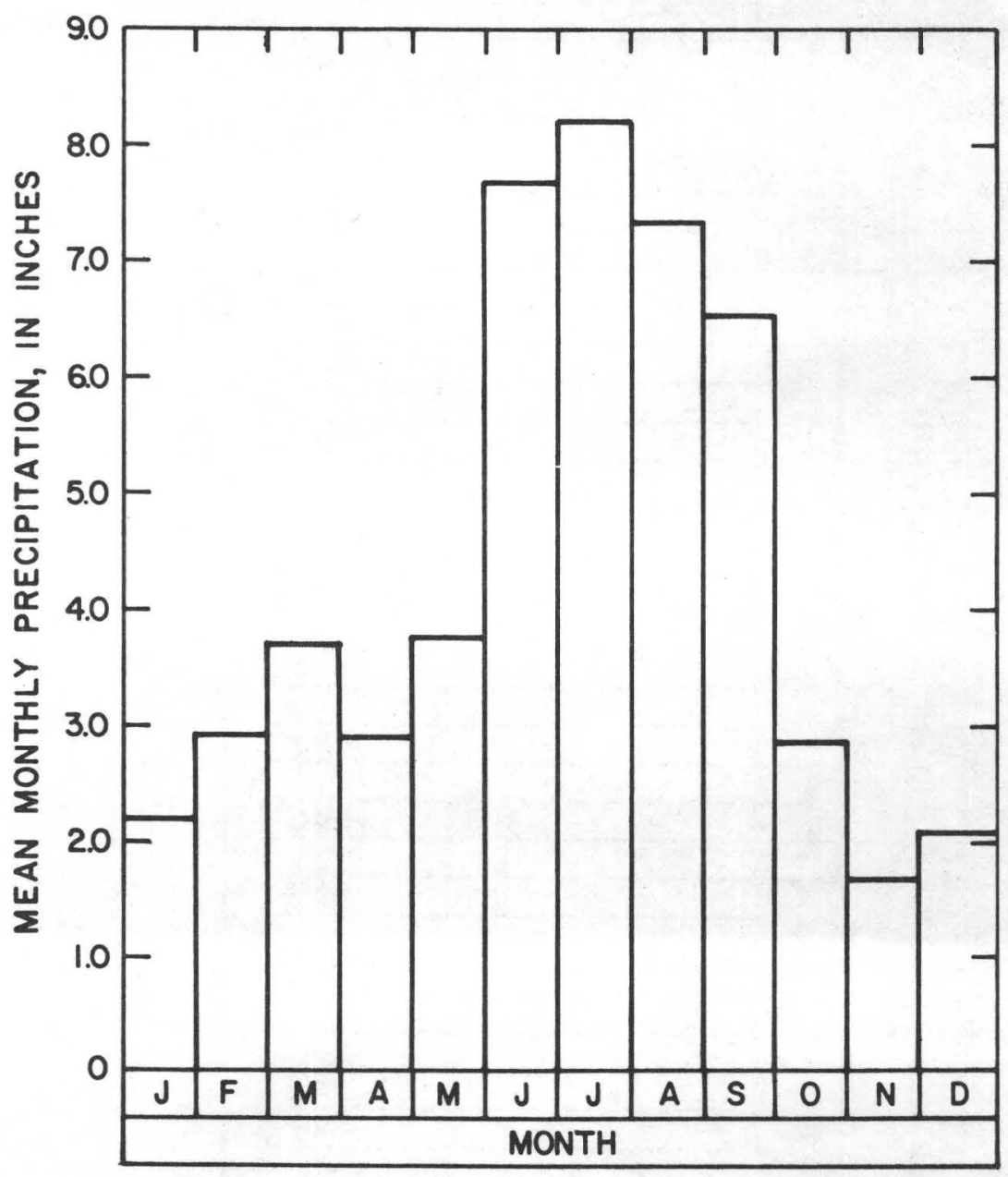

Figure 4.--Long-term average monthly precipitation, 1931-76 
Citrus processing plants have been withdrawing water from the Floridan aquifer in this area since the early $1940^{\prime} \mathrm{s}$. The pumpage is centered in what is apparently a natural trough in the potentiometric surface of the Floridan aquifer, (Tibbals, oral commun. 1978). The axis of this trough is coincident with the western boundary of the Green Swamp area. Perhaps one-half to two-thirds of this pumpage, estimated at $17 \mathrm{Mgal} / \mathrm{d}$ on an annual basis since 1961, is derived from outsici? the Green Swamp area and crosses the boundary of the area before reaching the wells. The effluent from these plants is discharged through a canal to the Withlacoochee River east of Dade City.

\section{Outflow}

The water received from rainfall in the Green Swamp area is discharged by (1) streams which flow from the area, (2) ground-water outflow through the Floridan and near-surface sand aquifers, or (3) evapotranspiration--that water evaporated back to the atmosphere plus that transpired by plants. There are no known significant ground-water withdrawals that are subsequently transported from the Green Swamp except by streamflow, evapotranspiration or ground-water outflow.

\section{Streamflow}

The long-term mean annual runoff from the Green Swamp area is about $10 \mathrm{in}$. which is equivalent to about $415 \mathrm{Mgal} / \mathrm{d}$ or about 19 percent of the long-term average annual rainfall. Although streamflow has been measured in the Withlacoochee River at Trilby since 1928 (U.S. Geological Survey, 1931), these records do not accurately represent the total natural runoff from the Withlacoochee basin (which is 82 percent of the Green Swamp area) because of a natural diversion into the Hillsborough River at Richland several miles upstream from Trilby.

The second longest continuous records of streamflow are those from three stations (table 1) established in the area in 1959. These records give excessive values for the long-term runoff from their respective basins because of the extremely large annual flows during the first 2 years of record, 1959 and 1960. For example, the combined average streamflow for these 2 years in Big Creek near Clermont is almost two times the next highest year (fig. 5). The third largest annual flow at Trilby occurred prior to 1959 and it is about 20 percent lower than either 1959 or 1960 (fig. 6).

Records at stations with shorter periods of record can be extended by developing a regression relation between their monthly means and monthly means at Trilby. The relation between flow at Trilby and flow at the short-term stations will change when the Withlacoochee River reaches a stage of $78.5 \mathrm{ft}$ above mean sea level at Richland. At this stage water flows into the Hillsborough River through a natural overflow channel. At higher stages, more than 25 percent of the flow from 
Table 1.-- Stream gaging stations used for calculation of runoff from the Green Swamp area

\begin{tabular}{|c|c|c|c|c|}
\hline $\begin{array}{l}\text { Station } \\
\text { number }\end{array}$ & $\begin{array}{l}\text { Station } \\
\text { name }\end{array}$ & $\begin{array}{l}\text { Drainage } \\
\text { area } \\
\text { sq. mi. }\end{array}$ & $\begin{array}{l}\text { Period of } \\
\text { record } \\
\text { (complete } \\
\text { water year) }\end{array}$ & $\begin{array}{l}\text { Stream } \\
\text { gaging site } \\
\text { index number } \\
\text { of fig. } 2\end{array}$ \\
\hline 02236500 & $\begin{array}{l}\text { Big Creek near } \\
\text { Clermont, Florida }\end{array}$ & 68 & $1959-76$ & 1 \\
\hline 02310800 & $\begin{array}{l}\text { Withlacoochee River } \\
\text { near Eva, Florida }\end{array}$ & 130 & $1959-76$ & 2 \\
\hline 02310947 & $\begin{array}{l}\text { Withlacoochee River } \\
\text { near Cumpressco, } \\
\text { Florida }\end{array}$ & 280 & $1968-76$ & 3 \\
\hline 02312000 & $\begin{array}{l}\text { Withlacoochee River } \\
\text { near Trilby, } \\
\text { Florida }\end{array}$ & 570 & $1931-76$ & 4 \\
\hline 02312180 & $\begin{array}{l}\text { Little Withlacoochee } \\
\text { River near } \\
\text { Tarrytown, Florida }\end{array}$ & 85 & $1967-76$ & 5 \\
\hline 02312200 & $\begin{array}{l}\text { Little Withlacoochee } \\
\text { River at Rerdell, } \\
\text { Florida }\end{array}$ & 145 & $1959-75$ & 6 \\
\hline
\end{tabular}




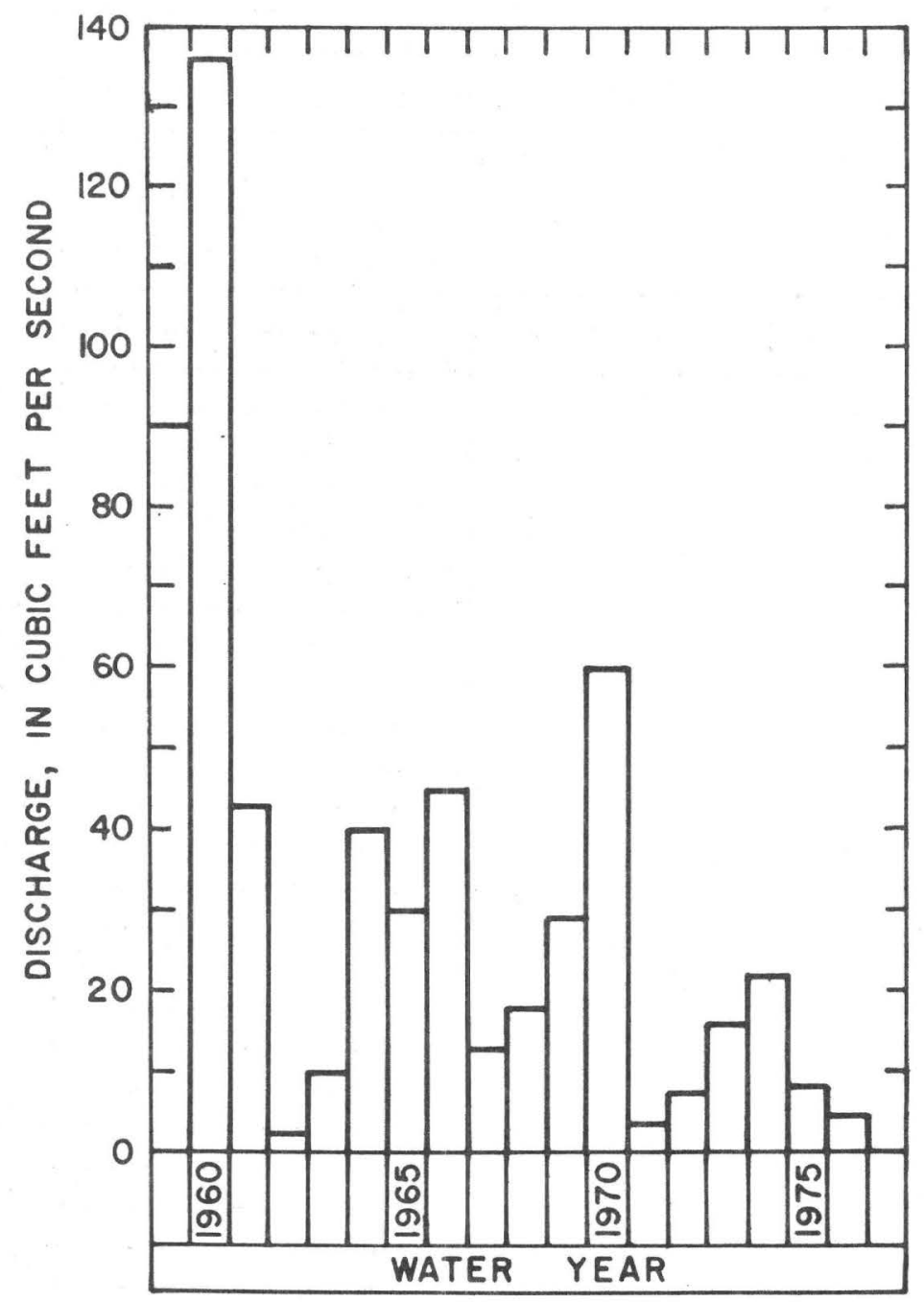

Figure 5.--Annual average streamflow for Big Creek near Clermont 


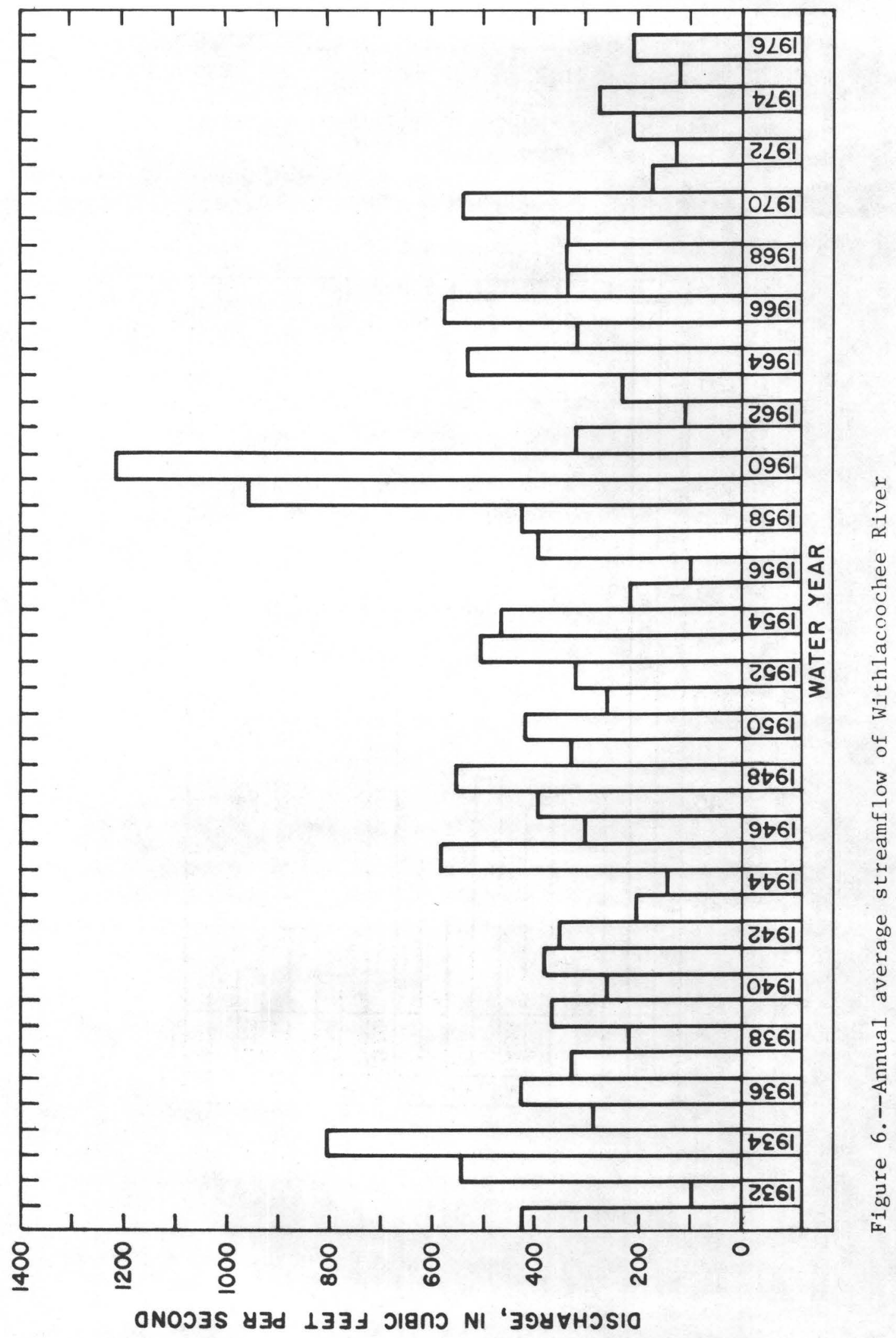


the upper Withlacoochee River may be naturally diverted into the Hillsborough River (Pride and others, 1966, p. 39). However, this change will be consistent in time for any given stage above the natural overflow elevation and thus the usefulness of the relationship between flows at the long-term and short-term records is not impaired although the volume of flow diverted may not be known.

A simple linear regression equation was developed for each shortterm station listed in table 1 by using a period of concurrent monthly flows at the Trilby station. These equations are given in table 2 for all the short-term stations except the station on the Little Withlacoochee River near Tarrytown. The equations for some months at this station gave flow estimates which were excessively high. This was attributed to the lack of occurrence of the full range of flows during the short period of record. This does not adversely affect the determination of runoff from the Little Withlacoochee basin because the station downstream at Rerdell has a longer period of flow data and 95 percent or more of this basin is upstream from the Rerdel1 gage.

The estimated monthly runoff prior to the beginning of record and the measured monthly runoff for the period of record were used to calculate both long-term monthly runoff and long-term annual runoff at the short-term stations. The annual runoff was computed by adding the monthly flow values.

The estimated long-term annual runoff of $10 \mathrm{in.}$ for the entire Green Swamp area is an area-weighted average calculated from the values given in table 3 for Big Creek near Clermont, the Withlacoochee River above Cumpressco and the Little Withlacoochee River above Rerdell. Ten in. appears to be a reasonably accurate estimate of runoff from the area for the following reasons: (1) the drainage area of the three above mentioned basins is equal to about 57 percent of the total Green Swamp area; (2) topographic conditions in the Withlacoochee basin below Cumpressco indicate that the runoff from this part of the Green Swamp is less than the $12 \mathrm{in}$. of runoff above Cumpressco but more than the 8 in. from the Little Withlacoochee River; and (3) the measured runoff at Trilby (which does not include water naturally diverted into the Hillsborough River) is about 18 percent less than the average runoff from the Withlacoochee basin upstream from Cumpressco and from the Little Withlacoochee basin above Rerdell.

The long-term annual runoff varies from about 5.5 in. in the headwaters of the Withlacoochee River above the Eva gage to over 12 in. for a11 of the upper Withlacoochee basin above the Cumpressco gage (table 3). The runoff for that part of the Withlacoochee which is between the Eva gage and the Cumpressco gage is $18 \mathrm{in.} \mathrm{The}$ variation in runoff from year to year is large as illustrated by the difference in maximum and minimum observed annual flows of Big Creek near Clermont; the maximum is over 50 times greater than the minimum (fig. 5). 
Table 2.--Summary of streamflow regression analysis used to extend short-term records to the 1931-76 period of record for Withlacoochee River at Trilby. Equations have the form $\log y=a+b \log x$

$\begin{array}{lcccc}\text { Station and month } & \begin{array}{c}\text { Regression } \\ \text { constant } \\ (\mathrm{a})\end{array} & \begin{array}{c}\text { Regression } \\ \text { coefficient } \\ (\mathrm{b})\end{array} & \begin{array}{c}\text { Standard } \\ \text { error of } \\ \text { estimate }\end{array} & \begin{array}{c}\text { Correlation } \\ \text { coefficient }\end{array} \\ \begin{array}{l}\text { Big Creek near } \\ \text { Clermont }\end{array} & & & & \\ \text { October } & -1.33 & 1.08 & 0.36 & 0.84 \\ \text { November } & -1.97 & 1.40 & .41 & .84 \\ \text { December } & -2.70 & 1.75 & .38 & .83 \\ \text { January } & -2.90 & 1.74 & .33 & .89 \\ \text { February } & -2.07 & 1.39 & .26 & .91 \\ \text { March } & -1.92 & 1.28 & .30 & .93 \\ \text { April } & -3.02 & 1.70 & .27 & .97 \\ \text { May } & -4.19 & 2.16 & .40 & .91 \\ \text { June } & -1.91 & 1.14 & .69 & .60 \\ \text { July } & -1.24 & .98 & .50 & .74 \\ \text { August } & -1.19 & .97 & .36 & .77 \\ \text { September } & -1.67 & 1.15 & .29 & .83\end{array}$

Withlacoochee River near Eva

$\begin{array}{lllll}\text { October } & -1.47 & 1.18 & .22 & .94 \\ \text { November } & -2.70 & 1.70 & .42 & .88 \\ \text { December } & -3.36 & 2.04 & .41 & .85 \\ & & & & \\ \text { January } & -3.72 & 2.11 & .40 & .90 \\ \text { February } & -3.16 & 1.88 & .33 & .92 \\ \text { March } & -2.58 & 1.61 & .31 & .95 \\ \text { April } & -3.78 & 2.02 & .56 & .91 \\ \text { May } & -4.20 & 2.19 & .54 & .86 \\ \text { June } & -2.11 & 1.36 & .81 & .61 \\ & & & & .75 \\ \text { July } & -1.72 & 1.33 & .65 & .74 \\ \text { August } & -.86 & .97 & .39 & .80 \\ \text { September } & -1.14 & 1.09 & .29 & \end{array}$


Table 2.--Summary of streamflow regression analysis used to extend shortterm records to the $1931-76$ period of record for Withlacoochee River at Trilby. Equations have the form $\log y=a+b \log x$ (continued)

\begin{tabular}{|c|c|c|c|c|}
\hline Station and month & $\begin{array}{l}\text { Regression } \\
\text { constant } \\
\text { (a) }\end{array}$ & $\begin{array}{l}\text { Regression } \\
\text { coefficient } \\
\text { (b) }\end{array}$ & $\begin{array}{l}\text { Standard } \\
\text { error of } \\
\text { estimate }\end{array}$ & $\begin{array}{l}\text { Correlat } \\
\text { coeffici }\end{array}$ \\
\hline \multicolumn{5}{|l|}{$\begin{array}{l}\text { Withlacoochee River } \\
\text { near Cumpressco }\end{array}$} \\
\hline $\begin{array}{l}\text { October } \\
\text { November } \\
\text { December }\end{array}$ & $\begin{array}{l}-0.98 \\
-2.51 \\
-3.45\end{array}$ & $\begin{array}{l}1.26 \\
1.82 \\
2.22\end{array}$ & $\begin{array}{r}0.21 \\
.30 \\
.45\end{array}$ & $\begin{array}{r}0.94 \\
.95 \\
.90\end{array}$ \\
\hline $\begin{array}{l}\text { January } \\
\text { February } \\
\text { March }\end{array}$ & $\begin{array}{l}-2.64 \\
-2.89 \\
-2.50\end{array}$ & $\begin{array}{l}1.88 \\
1.99 \\
1.83\end{array}$ & $\begin{array}{l}.45 \\
.32 \\
.46\end{array}$ & $\begin{array}{l}.88 \\
.95 \\
.90\end{array}$ \\
\hline $\begin{array}{l}\text { April } \\
\text { May } \\
\text { June } \\
\text { 1./April-May-June }\end{array}$ & $\begin{array}{l}-3.44 \\
-5.02 \\
-4.90 \\
-3.98\end{array}$ & $\begin{array}{l}2.18 \\
2.88 \\
2.95 \\
2.43\end{array}$ & $\begin{array}{l}.34 \\
.64 \\
.66 \\
.53\end{array}$ & $\begin{array}{l}.97 \\
.71 \\
.84 \\
.87\end{array}$ \\
\hline $\begin{array}{c}\text { July } \\
\text { August } \\
\text { September } \\
1 / \text { July-August- } \\
\text { September }\end{array}$ & $\begin{array}{r}-1.61 \\
.35 \\
-.62\end{array}$ & $\begin{array}{l}1.52 \\
8.25 \\
1.18\end{array}$ & $\begin{array}{l}.74 \\
.27 \\
.08\end{array}$ & $\begin{array}{l}.77 \\
.75 \\
.98 \\
.90\end{array}$ \\
\hline
\end{tabular}

Little Withlacoochee River at Rerde11

$\begin{array}{lllll}\text { October } & -1.84 & 1.41 & .36 & .90 \\ \text { November } & -1.23 & 1.19 & .38 & .81 \\ \text { December } & -1.96 & 1.54 & .37 & .80 \\ & & & & .92 \\ \text { January } & -2.11 & 1.58 & .26 & .94 \\ \begin{array}{l}\text { February } \\ \text { March }\end{array} & -1.70 & 1.44 & .22 & .94 \\ \text { April } & -1.53 & 1.35 & .28 & .83 \\ \text { May } & -1.28 & 1.22 & .49 & .60 \\ \text { June } & -2.07 & 1.48 & .81 & .62 \\ & -1.63 & 1.25 & .72 & .81 \\ \text { July } & -1.67 & 1.28 & .52 & .83 \\ \text { August } & -1.61 & 1.29 & .40 & .89 \\ \text { September } & -2.19 & 1.53 & .28 & \\ \text { e equation from } & 3 \text { months data used to estimate flows for these } \\ \text { hs. } & & & & \end{array}$


Table 3.--Long-term average annual runoff from four basins in the Green Swamp area, 1931-76

(Values were computed from monthly flows. Those monthly flows prior to the beginning of record were estimated by simple linear regression.)

\begin{tabular}{lcc} 
Station & $\begin{array}{c}\text { Long-term average } \\
\text { annual runoff, } \\
\text { in inches }\end{array}$ & $\begin{array}{c}\text { Percent } \\
\text { occurring } \\
\text { during } \\
\text { July-October }\end{array}$ \\
\hline Big Creek near Clermont & 5.71 & 51 \\
$\begin{array}{l}\text { Withlacoochee River } \\
\text { near Eva }\end{array}$ & 5.44 & 57 \\
$\begin{array}{l}\text { Withlacoochee River } \\
\text { near Cumpressco }\end{array}$ & 12.09 & 65 \\
$\begin{array}{l}\text { Little Withlacoochee } \\
\text { River near Rerdel1 }\end{array}$ & 8.17 & 57
\end{tabular}


May and September represent the seasonal extremes in runoff from the Big Creek, Withlacoochee and Little Withlacoochee basins (fig. 7). Except for the Big Creek basin, the September runoff is about 15 times the May runoff; the difference for Big Creek is only about 9 times. This difference is attributed to the release of a greater volume of water from the sand aquifer during the period October through Fchruary in the lower part of the Big Creek basin than in the Withlacoochee basin. The lower Big Creek basin has sand-hill terrain while the liwer part of the Withlacoochee basin above the gage near Eva has few sand hills but vast expanses of swampland.

The reliability of the monthly runoff figures appears to be good. An indirect evaluation shows that all but one or two of the annual values, summed from the monthly regression relation, are within 25 percent of the relation defined by the observed annual values from the period of concurrent record. An example of this indirect evaluation, which generally follows the method outlined by Thomas (1967, p. 3), is shown in figure 8 for the Trilby and Cumpressco data. The low-flow months prior to 1940 may be too low because of the discharge from the Dade City canal to the Withlacoochee River several miles upstream from the Trilby station. This does not appear to be a serious problem because the total flow for the 2 lowest months of flow is less than 5 percent of the annual flow. Moreover, the difference between the measured flow during the period of record and the estimated flow prior to the beginning of record is about 25 percent for the lowest month and about 6 percent for the second lowest month.

\section{Ground Water}

Ground-water outflow accounts for the smallest volume of discharge from the Green Swamp area and is estimated to be about 2 in. on a long-term annual basis. This is equivalent to about $83 \mathrm{Mgal} / \mathrm{d}$ or about one-fifth the volume discharged by streamflow. Ground water may be discharged from the area through either the near-surface sand aquifer or the underlying Floridan aquifer. However, Pride and others (1966, p. 108, 117) found that less than 5 percent of the ground-water outflow from the area was through the sand aquifer, occurring chiefly along the eastern boundary of the area. Therefore, the discussion of ground-water outflow will deal primarily with the Floridan aquifer.

Within the Green Swamp area the principal direction of flow in the Floridan aquifer is outward from a dome on the potentiometric surface located in the southeastern part of the area (fig. 9). Many potentiometric maps have been made for this aquifer (Stringfield, 1936, Unklesbay, 1944, Healy, 1962, Stewart and others, 1971, and Ryder and others, 1977), but the only major effort to quantify the outflow from the Green Swamp area on an annual basis is that of Pride and others (1966, p. 109-118). They used a flow net analysis for a period of high water levels (November 1959) and a period of low water levels 

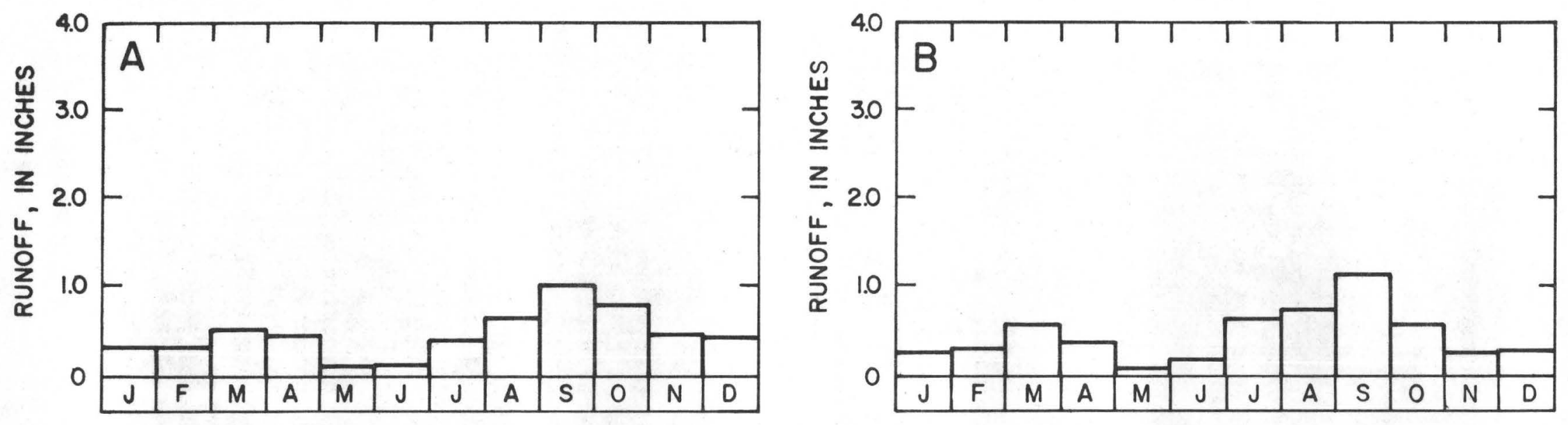

$\stackrel{\infty}{\infty}$
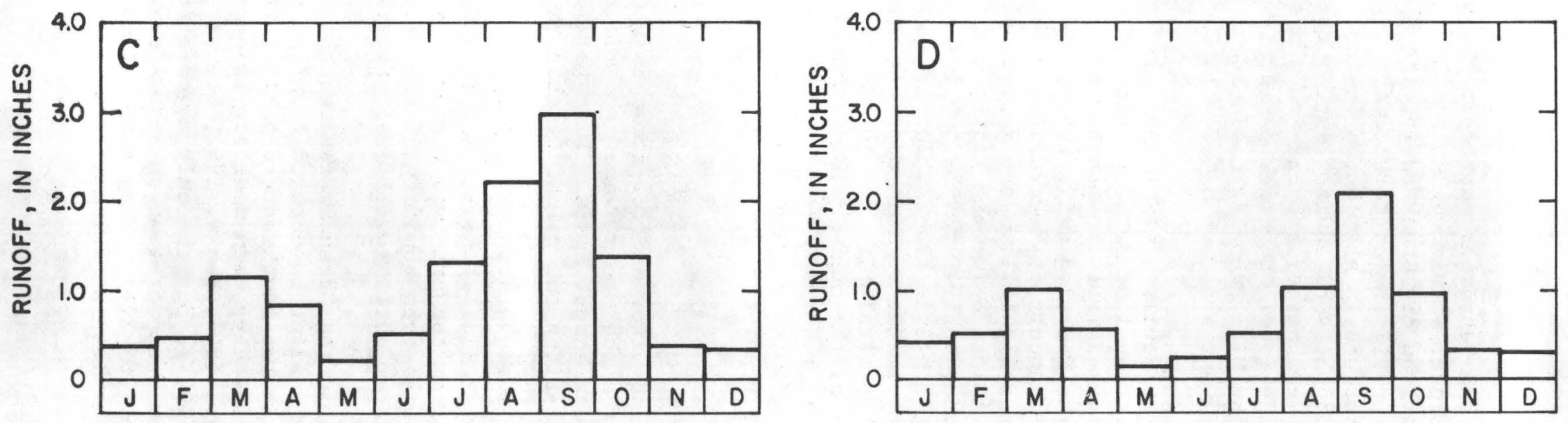

Figure 7.--Long-term average monthly runoff at A, Big Creek near Clermont; B, Withlacoochee River near Eva; C, Withlacoochee River near Cumpressco; and D, Little Withlacoochee River near Rerdell 


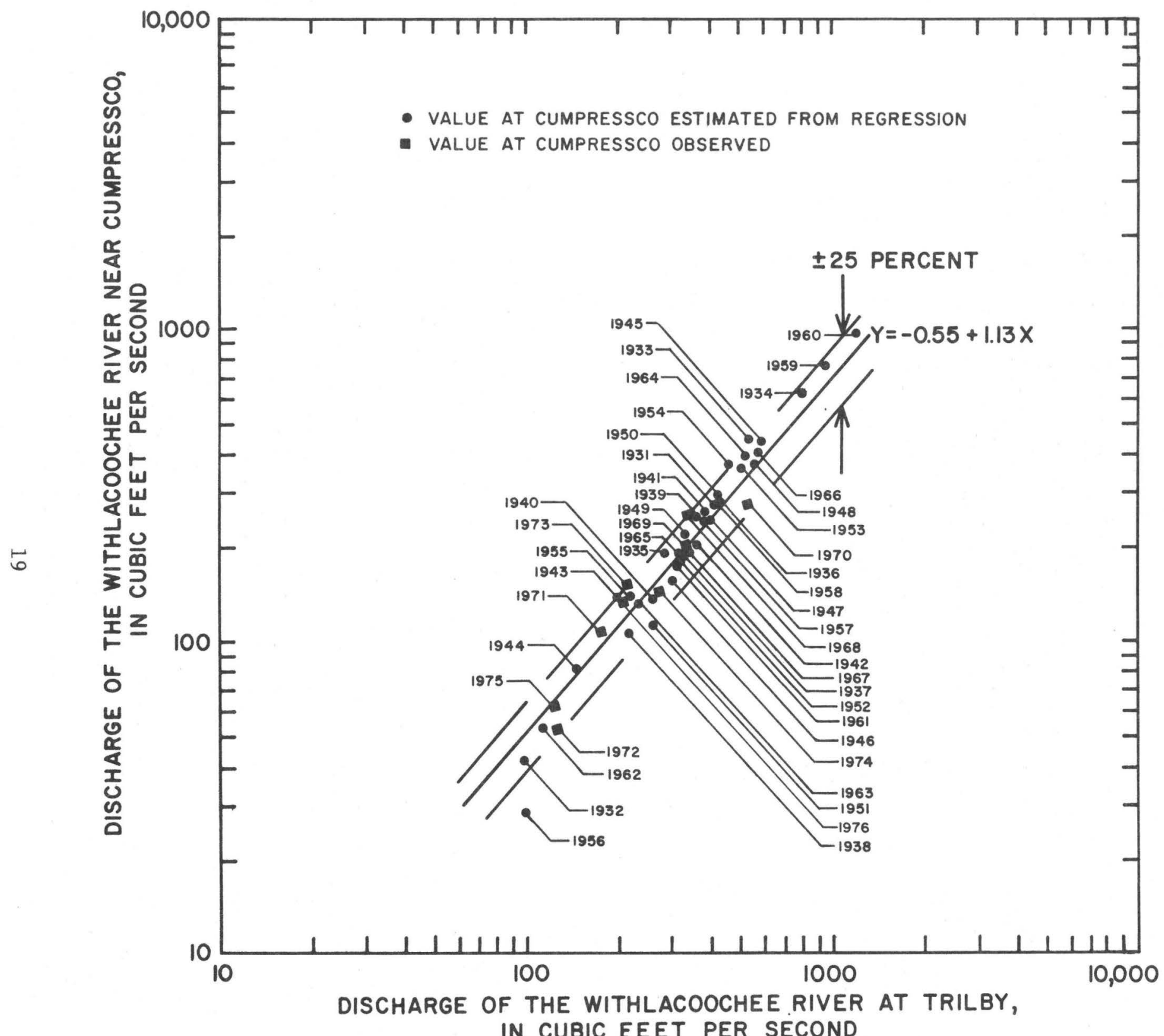

Figure 8.--Relation of annual average streamflow of the Withlacoochee River at Trilby to the annual average streamflow of the Withlacoochee River near Cumpressco, 1931-76 


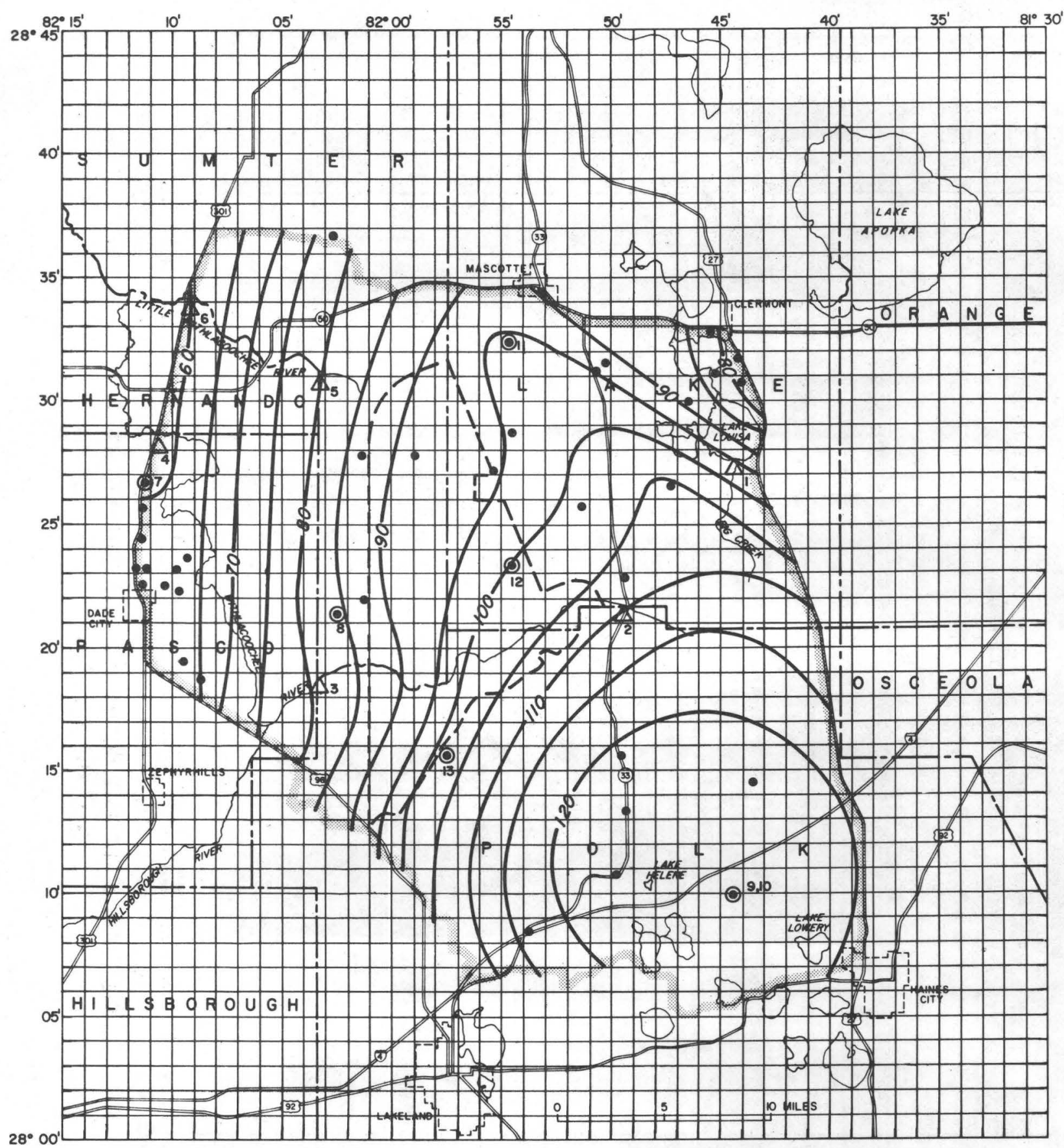

\section{EXPLANATION}

WMOMU BOUNDARY OF GREEN SWAMP AREA

- FLOOD DETENTION AREA PROPOSED BY SOUTHWEST FLORIDA WATER MANAGEMENT DISTRICT
-90- POTENTIOMETRIC CONTOUR-SHOWS ALTITUDE AT WHICH WATER LEVEL WOULD HAVE STOOD IN TIGHTLY CASED WELLS. O OBSERVATION WELL WITH CONTOUR INTERVAL 5 FEET. DATUM IS MEAN SEA LEVEL $\triangle$ STREAM GAGING STATION

- observation well RECORDER

I HYDROLOGIC SITE INDEX NUMBER

Figure 9.--Potentiometric surface of the Floridan aquifer, May 1977 
(May 1962). The subsequent estimates of ground-water outflow were 1.8 in. for November 1959, 2.6 in. for May 1962, and 1.9 in. as an average for 1959-61.

Two lines of evidence tend to support the assumption that the 2-in. estimate by Pride and others (1961) for annual ground-water outflow is currently (1978) valid--(1) the range of annual fluctuations in observation wells and (2) the lack of long-term significant change in the potentiometric surface of the Floridan aquifer (fig. 11). The long-term average monthly water level fluctuation in three index wells shown in figure 10 is less than $5 \mathrm{ft}$. This compares with an average water level fluctuation in these three wells of about $6 \mathrm{ft}$ during November 1959 to May 1962 for which the 2-in. figure was computed by Pride and others.

\section{Evapotranspiration}

Evapotranspiration is the loss of water to the atmosphere from a land area through transpiration of plants and evaporation from the soil or any exposed water body. Evapotranspiration in the Green Swamp area averages about $40 \mathrm{in}$./yr. This value is obtained by subtracting the two previously discussed outflows, runoff (10 in.) and ground-water outflow (2 in.), from the 52 in. of rainfall, assuming no long-term net change in either ground- or surface-water storage. As noted by Lee (1970, p. 1328) there are no adequate methods for predicting evapotranspiration from natural catchments (that is, stream basins). Therefore, we must depend upon estimates like the above or some other approximation of evaporation and transpiration to obtain an idea of the volume of water removed from a large area like the Green Swamp.

Other estimates of evapotranspiration from the Green Swamp area and an empirical estimate of potential evapotranspiration indicate the value of $40 \mathrm{in./yr}$ is apparently a good working value for long-term annual evapotranspiration. Estimates of evapotranspiration by Pride and others (1966, p. 111) vary from 36.5 to 44.7 in. for four stream basins within the Green Swamp area. Average values for 1959-61, which include the years of maximum and minimum annual rainfall, were 38.3 and $41.8 \mathrm{in.}$ for basins located in the eastern and western parts of the Green Swamp. Potential evapotranspiration estimated by the method first introduced by Thornthwaite (1944) and later outlined by Thornthwaite and Mather (1957), is about $46 \mathrm{in./yr}$ or 14 percent greater than rates computed from water budget estimates. Although the Thornthwaite method is an empirical method subject to large uncertainties, it gives a fair indication of the relative seasonal variation in evapotranspiration (fig. 12).

\section{Suitability of Outflows as Source of Water Supply}

The development of water supplies in the Green Swamp area requires the diversion of water from one or more of the three natural outflows. 


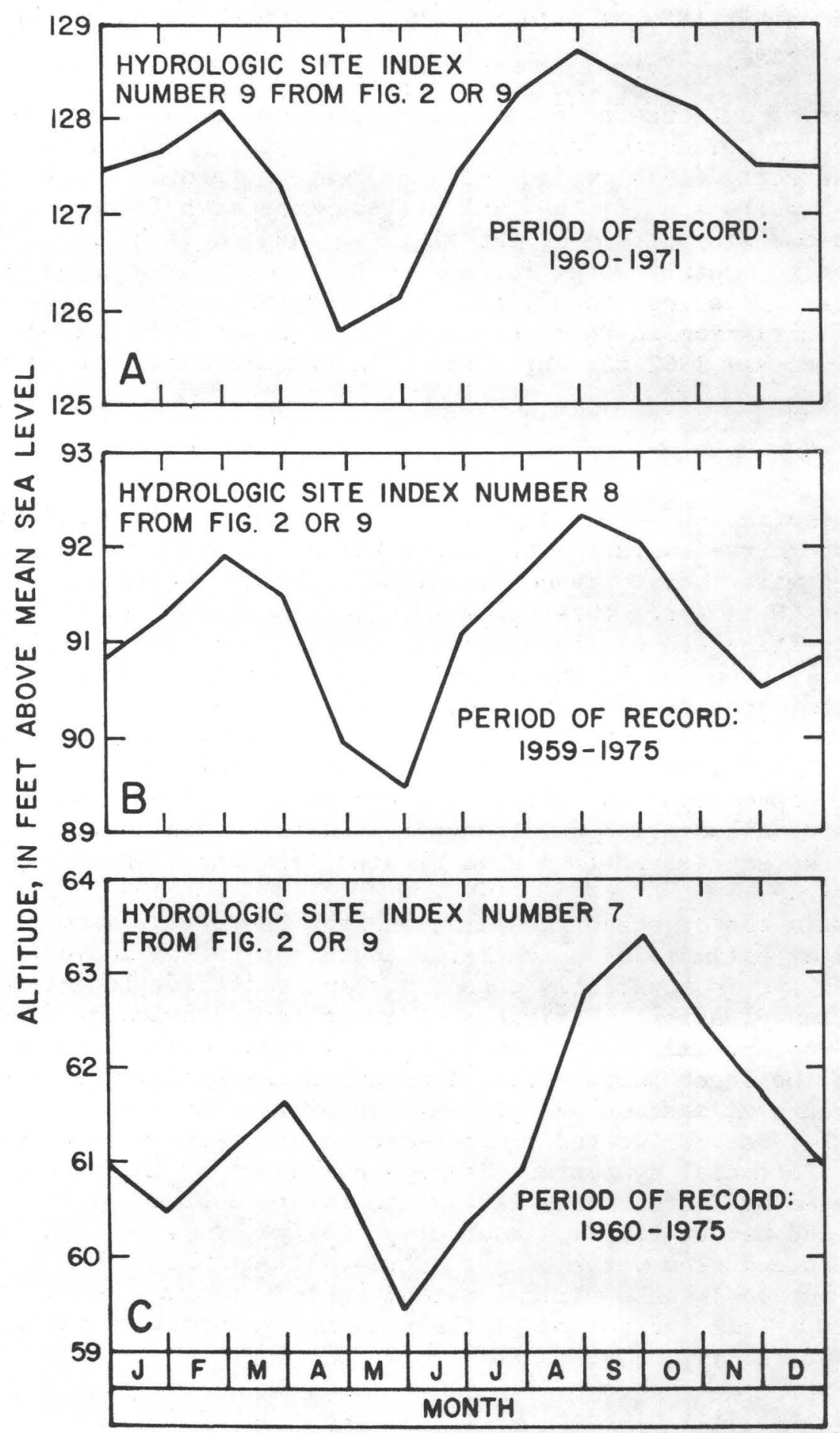

Figure 10.--Average month-end water levels in the Floridan aquifer 


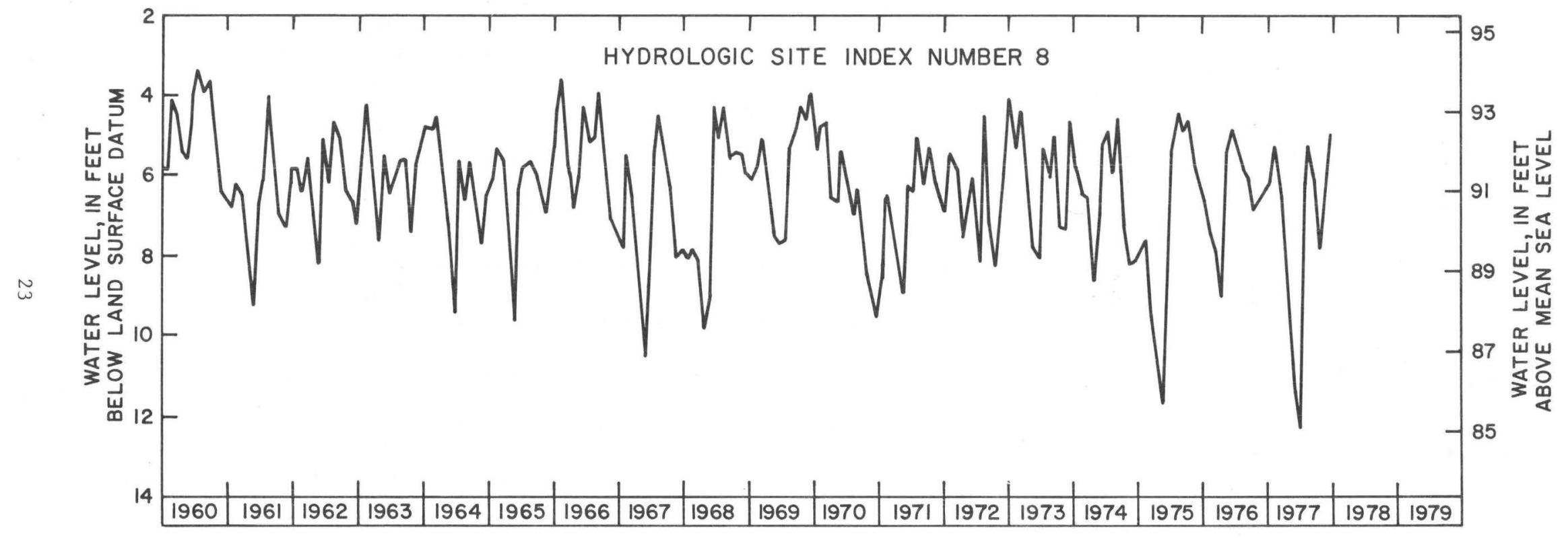

Figure 11.--Month-end water levels in the Floridan aquifer 1960-77 


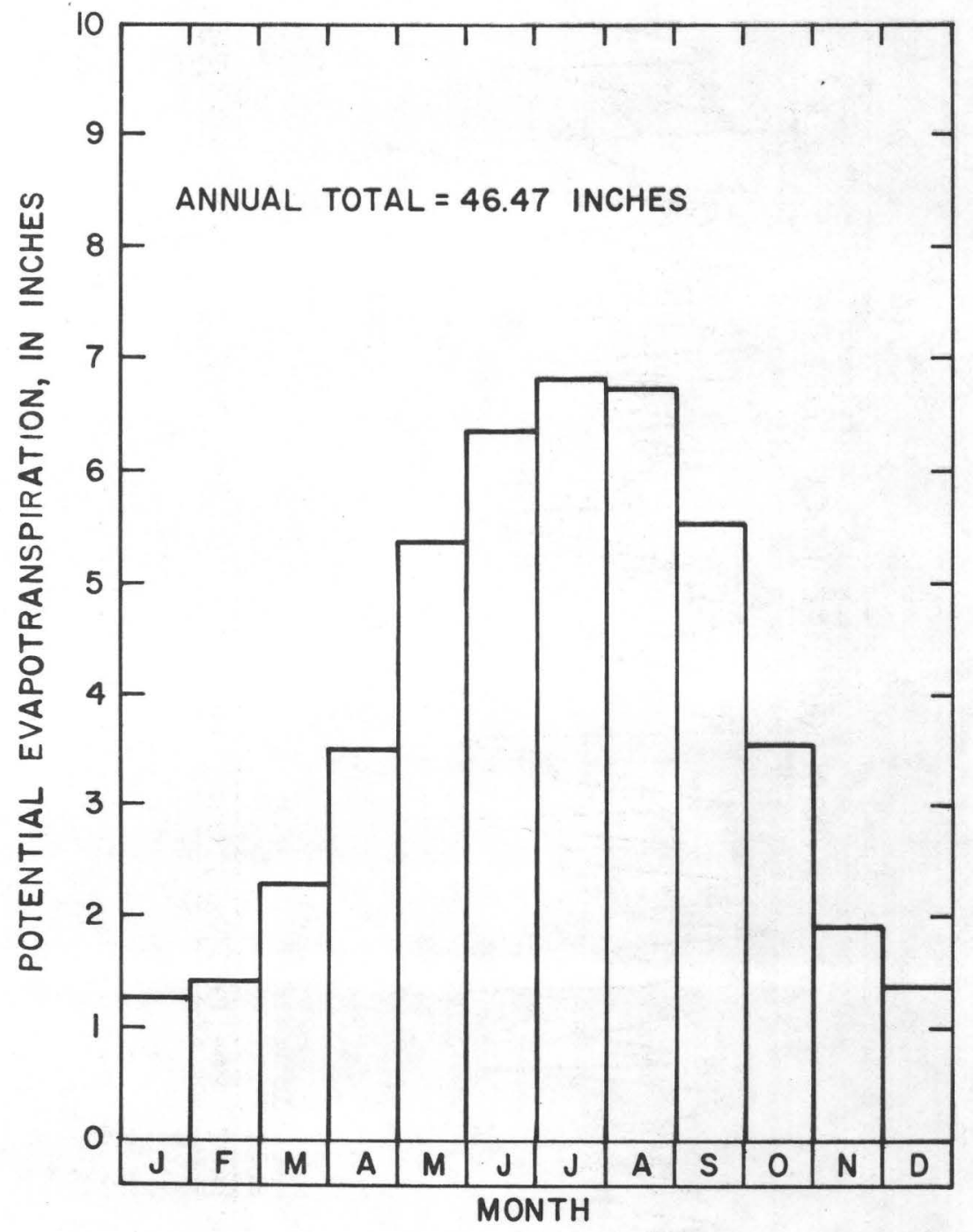

Figure 12.--Monthly potential evapotranspiration estimated by the Thornthwaite method, 1931-76 
For the purposes of this analysis, diversion is considered to be removal of the water from the area without potential for reuse within the Green Swamp. The three outflows are interrelated and a diversion from one can have a significant effect on one or both of the others.

The suitability of each outflow is evaluated on the basis of (1) availability of water for diversion, (2) seasonal dependability or the feasibility of providing a storage reservoir, and (3) the iikelihood of diverting the water.

\section{Streamflow}

Water that leaves the area as streamflow is readily available when it is in the stream channels but diverting this water for a perennial water supply would not be feasible due to the seasonal variability of streamflow. From 51 to 65 percent of the runoff occurs during the 4 months July through October (table 3). No flow has been observed frequently at all stations except Trilby during the months of April through June when water demand is at a maximum. Therefore, total dependence upon diverted streamflow for a perennial water supply would require some type of storage facility where large quantities of water could be stored during periods of high streamflow and subsequently released during periods of low streamflow.

The combination of terrain and the annual water balance makes surface reservoirs unattractive as a means of overcoming the problem of seasonal variability in streamflow. Because of the flat terrain, any reservoir with appreciable storage capability will have an excessively large surface area and a relatively shallow depth. For example, the 90-ft topographic contour crosses the Withlacoochee River near the levee line for the proposed flood detention area (fig. 2) and the proposed elevation of the conservation pool is only $10 \mathrm{ft}$ higher at $100 \mathrm{ft}$ above mean sea level; the conservation pool would cover about $68 \mathrm{mi}^{2}$ if a common elevation is maintained in the Little Withlacoochee River portion of the flood detention area. The flood control pool would be $7 \mathrm{ft}$ higher than the conservation pool and would cover about $112 \mathrm{mi}^{2}$.

Such a large open-water surface would increase the volume of water now leaving the Green Swamp in the vapor state. The potential evapotranspiration exceeds precipitation for about 33 percent of the year (figs. 4 and 12). Moreover, Pride and others (1966, p. 118) found that the measured evaporation from a small lake was 16 in. more than the average annual evapotranspiration calculated for a 3-yr period. They concluded that exposure of the water surface by impounding water in a reservoir would increase average annual evaporation by about 9 in. The increase in evaporation for a $68-\mathrm{mi}^{2}$ conservation pool is equivalent to about $0.7 \mathrm{in.}$ over the entire Green Swamp area. The redistribution if the 1 to 3 in. of runoff which would remain after the increase in 
evaporation from the $68-\mathrm{mi}^{2}$ area is not significant because it represents about 0.2 in. of water over the entire Green Swamp area.

A reservoir is needed which has a large storage capacity and a small surface area exposed to evaporation in the months of April, May, October and November. The near-surface sand aquifer appears to have many of the required properties of such a reservoir. Therefore, indirectly diverting runoff to ground-water recharge may be the most favorable utilization of streamflow for water supplies. The flat swampy terrain in the Green Swamp is favorable for this type of diversion because the water is naturally held over a large area for a relatively long period of time before it reaches the stream channels. Storage within the stream basins is reflected in the lag time between precipitation and runoff; the month of maximum runoff (September) occurs 2 months after the month of maximum rainfall (figs. 4 and 7). June and July have almost equal rainfall but July runoff is two to three times greater than June runoff (fig. 7).

\section{Ground Water}

Ground-water outflow from the area is readily available and could be diverted for water supplies by developing well fields in the Floridan aquifer. Diversion of ground water is attractive as a source of water supply because it is seasonally dependable and wells can be located practically anywhere in the area. The Floridan aquifer constitutes a vast reservoir which has the storage capacity to supply a quantity of water equal to at least the $2 \mathrm{in.}$ ( $83 \mathrm{Mgal} / \mathrm{d}$ ) of groundwater outflow during the annually occurring periods of low rainfall and during sustained periods of less than average rainfall.

A well field in the upper portion of the Floridan aquifer would locally increase the recharge to this aquifer from the overlying sand aquifer by leakage. If this type development is extensive enough, some dewatering of the sand aquifer will occur and the empty space in the sand aquifer will be available for storage of significant quantities of water which now leave the area as streamflow. Thus, the potential for developing water supplies in excess of $83 \mathrm{Mgal} / \mathrm{d}$ exists in the area and will be explored further in a later section of this report.

\section{Evapotranspiration}

Diversion of a significant quantity of water from evapotranspiration for water supplies does not appear as promising in the Green Swamp as diversion of either runoff or ground-water outflow. Water which leaves the area in the vapor state is not directly available for diversion for water supplies. If the vaporization process could be short-circuited and, if storage capacity for the water thus retained 
in the area is available, this water could then be diverted for water supply. The sand aquifer has the potential for storing significant quantities of water.

A large quantity of water is removed from the area in the vapor state each year. The average monthly potential evapotranspiration is greater than 1 in. for every month of the year and greater than 5 in. for each of 5 months (fig. 12). Measured evaporation from Lake Helene was greater than 2 in. for all months during 1962 (Pride and others, 1966 , p. 106). The major problem related to possible diversion of water from this outflow is not seasonal variability or the availability of a storage reservoir but rather how to effect disruption of the vaporization process.

It would appear possible to disrupt the vaporization process in the Green Swamp area in at least two ways: (1) reducing the water surface exposed to direct evaporation or (2) moving water beyond the reach of plant rooots which transpire water directly from the saturated zone of the sand aquifer.

The largest water-surface area exposed to direct evaporation, and perhaps amenable to management, is the rainfall intercepted by the many layers of vegetation covering the Green Swamp area. Many studies of the effects of vegetation management on evapotranspiration have been made on small drainage basins (less than $5 \mathrm{mi}^{2}$ ) but the results have not been completely satisfying (Lee, 1970, p. 1327). Several of these studies have shown changes in runoff during the period of maximum runoff and minimum evapotranspiration and little or no change during the period of maximum potential evapotranspiration (Schneider and Ayer, 1961, Swank and Miner, 1968, Hibbert, 1971).

Vegetation management practices do not always produce the results anticipated when applied to natural drainage basins. The conversion of a hardwood forest on a small drainage basin in eastern North Carolina to low-growing grass decreased the runoff the first year after the change in vegetation (Hibbert, 1969); an increase in runoff was observed in 4 out of 6 years. The 2 years of unanticipated decrease in runoff was attributed to the intensity of fertilization and management of the grass, but the author warns against too broad an interpretation of the results.

There are no reliable estimates of the quantity of water transpired from the saturated zone of the sand aquifer in the Green Swamp area. Neither are there definitive studies of the requirements of the vegetation in the Green Swamp relative to the use of moisture from the saturated zone relative to the unsaturated zone. McQueen and Miller (1972, p. 49) found that some plant species commonly considered as phreatophytes in Arizona would use moisture from the saturated zone but could thrive on moisture from the unsaturated zone. 
A value of transpiration from the saturated zone of $0.19 \mathrm{in.} / \mathrm{mo}$ was reported by Daniel (1976, p. 362) for an area in southeast Alabama. If plants transpire water from the sand aquifer in the Green Swamp at this rate throughout the year, then this component of evapotranspiration outflow is about equal to the ground-water outflow of 2 in. Disruption of this part of the vaporization process would require lowering the potentiometric surface of the sand aquifer to some unknown level beyond the reach of those plants now using water from the saturated zone. Lowering of the potentiometric surface of the sand aquifer as a result of pumping from the Floridan aquifer would be gradual and might not disrupt this process because the ability of these plants to adapt to this condition is unknown. Moreover, the upper part of the sand aquifer might not become dewatered in all parts of the Green Swamp under achievable stress. In a similar sand aquifer east of Orlando, a connector well open to the full thickness of the aquifer and discharging about $60 \mathrm{gal} / \mathrm{min}$ did not significantly dewater the aquifer near land surface, even though a significant head drop near the bottom of this aquifer was observed and steady state had been reached (P. W. Bush, written commun., 1976).

Due to the complexities involved in any large scale disruption of the vaporization process and the lack of conclusive evidence (even from small drainage basins) that such disruption effects significant capture, the potential for diverting water from evapotranspiration outflow cannot be appraised with certainty. It is thus not considered as a source of water for the purposes of this evaluation.

\section{POTENTIAL OF GROUND WATER FOR SUPPLY}

About $274 \mathrm{Mgal} / \mathrm{d}$ could be developed for water supplies from the Floridan aquifer in the Green Swamp area if the 2 in. of ground-water outflow were diverted and if about one-half of the surface runoff could be diverted to recharge the near-surface sand aquifer on a long-term basis.

\section{Ground-Water System}

Ground-water withdrawals on the scale noted above require more than the examination of the flow system in the Floridan aquifer. The Floridan aquifer, the upper confining beds of the Floridan aquifer, and the near-surface sand aquifer make up one interconnected flow system. The following is an examination of each component in this flow system, a description of how each was synthesized into a digital prototype of the flow system, and the expected effects, as predicted by the prototype, of a $274 \mathrm{Mgal} / \mathrm{d}$ withdrawal from the Floridan aquifer.

\section{Near-Surface Sand Aquifer}

The near-surface sand aquifer is made up of Miocene and postMiocene sand and clayey sand deposits. This aquifer has been referred 
to as the nonartesian aquifer (Pride and others, 1961, p. 72), the clastic aquifer (Knochenmus and Hughes, 1976, p. 34) and the sand aquifer (Grubb, 1977). In this report the term near-surface sand aquifer or sand aquifer is used.

The sand aquifer is thickest in the eastern part of the Green Swamp where it is generally greater than $40 \mathrm{ft}$ thick in a $320-\mathrm{mi}^{2}$ area (fig. 13 and Grubb, 1977). In this area an aquifer thickness of $60 \mathrm{ft}$ is not uncommon and an aquifer thickness in excess of $100 \mathrm{ft}$ may occur locally near the Lake Wales ridge, which forms the eastern boundary of the Green Swamp.

The sand aquifer is less than $10 \mathrm{ft}$ thick in two areas in the western part of the Green Swamp which total about $170 \mathrm{mi}^{2}$ (fig. 13). These two areas are generally coincident with the area of 0 to $10-\mathrm{ft}$ depth to top of the Floridan aquifer shown by Pride and others (1966, fig. 31) but have a somewhat more irregular boundary.

Figure 13 was compiled from sand thickness data reported by Grubb (1977) and Rutledge and Grubb (1978). Within an area in southwest Lake County designated by Southwest Florida Water Management District as a flood detention area, Rutledge and Grubb (1978) show the sand aquifer is much thicker than previously indicated over an area of about $10 \mathrm{mi}^{2}$. The sand aquifer is greater than $40 \mathrm{ft}$ thick in about a $2 \mathrm{mi}^{2}$ part of this area.

The potential value of the sand aquifer relative to water supply is its large storage capacity rather than its potential for supplying water directly to pumping wells. Early in this century Matson and Sanford (1913, p. 389) reported the surficial sands in Polk County were being used for water supply. However, Stewart (1966, p. 79) reported typical yields of only 20 to $30 \mathrm{gal} / \mathrm{min}$ from the sand aquifer in Polk County. Even the maximum known yields of some irrigation wells, in excess of $100 \mathrm{gal} / \mathrm{min}$, are small compared to the $1,000 \mathrm{gal} / \mathrm{min}$ and greater yields.typical of the Floridan aquifer (Stewart, 1966, table 10). Hydraulic conductivities of 2.7 to $24.1 \mathrm{ft} / \mathrm{d}$ were reported by Pride and others (1966, p. 76) for the sand aquifer.

Specific yield values of 12.5 to 22.2 percent reported by Pride and others (1966, p. 77) for three sites within the Green Swamp suggest the storage capacity for this aquifer is large. A conservative value of 10 percent is assumed for specific yield for the purposes of this report because of (1) the abundance of very fine-grained sand and clay observed in core samples from this aquifer and (2) the small number of field determinations of specific yield. A practical illustration of the large storage capacity of this aquifer is the change in storage computed for the year 1961. For that year Pride and others (1966, p. 115) found the average net decline in water levels was equivalent to about $4.3 \mathrm{in}$. of water throughout the Green Swamp 


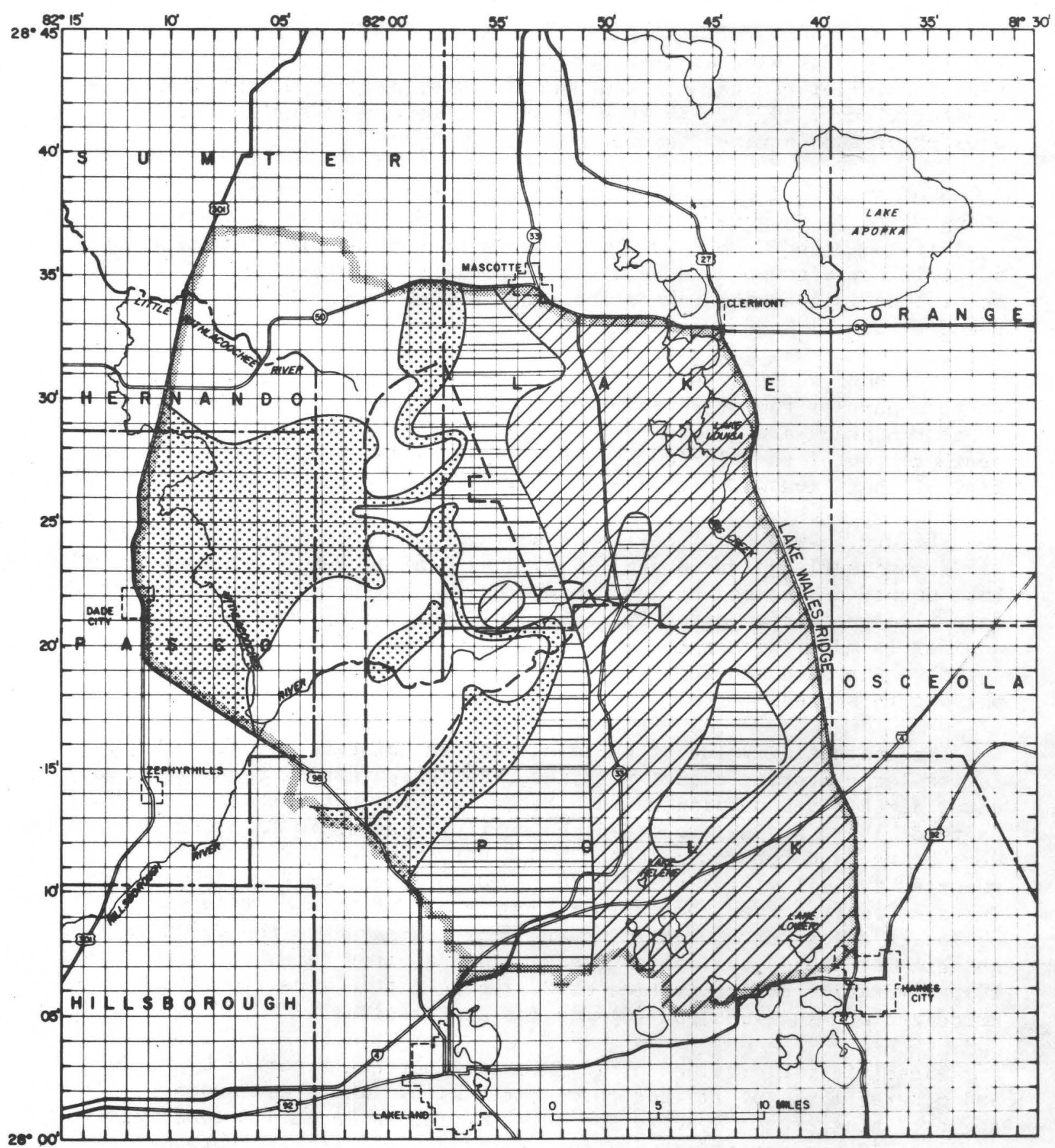

EXPLANATION

*:* BOUNDARY OF GREEN SWAMP AREA

- FLOOD DETENTION AREA PROPOSED BY SOUTHWEST FLORIDA WATER MANAGEMENT DISTRICT
SAND AQUIFER THICKNESS, IN FEET

$\square$ LESS THAN $10 \quad 20-40$
$\because \because 10-19$

Figure 13.--Thickness of the near-surface sand aquifer 
area. Long-term seasonal water-level fluctuations in this aquifer average about $1.5 \mathrm{ft}$ (fig. 14) which is equivalent to $1.8 \mathrm{in}$. of water.

The potentiometric surface of the near-surface sand aquifer for May 1977 was estimated for each 1-minute grid on the 7.5-minute topographic map using (1) the data from nine observation we1ls, (2) the relation of the potentiometric surface of the sand aquifer to the potentiometric surface of the Floridan aquifer, (3) records of streams and lake stage in the area, (4) location of swamps as shown on 7.5-minute topographic maps, and (5) general knowledge of the area. These estimates are believed to be within $2 \mathrm{ft}$ of the actual average potentiometric surface over each 1-minute area. The configuration of the resulting potentiometric surface is illustrated by the contour map shown as figure 15.

\section{Upper Confining Beds}

The upper confining beds of the Floridan aquifer in the Green Swamp are the Miocene clays, the residual clays in areas where the limestone is near land surface, or the sand aquifer in areas where neither of the clays is present. Stringfield (1936, p. 148) noted the Eocene Ocala Limestone, which is the uppermost part of the Floridan aquifer throughout most of the Green Swamp, is overlain by relatively impervious residual clays of the Miocene Hawthorn Formation in parts of northeastern Polk County, but that at least one well log revealed the occurrence of phosphatic marl on top of the Ocala Limestone. Confining beds consisting of clay and sandy clay were recognized by Pride and others (1966, p. 69) and apparently were assumed to occur with the sand aquifer throughout the Green Swamp. Several test holes were cored by Grubb (1977) in which no clay was penetrated and sand occurred on top of the uppermost limestone of the Floridan aquifer.

The thickness of the upper confining beds in the Green Swamp varies from less than $5 \mathrm{ft}$ to greater than $20 \mathrm{ft}$ for relatively large areas (fig. 16). These confining beds are generally thickest along the southern part of the Green Swamp and in two small areas in the northwest. Figure 16 was constructed from data previously reported by Grubb (1977) and Rutledge and Grubb (1978).

Vertical hydraulic conductivity of the upper confining beds was determined during this study by both laboratory and field methods. Values from the laboratory analyses range from 1.37 to $1.28 \times 10^{-6} \mathrm{ft} / \mathrm{d}$ (Grubb, 1977; Rutledge and Grubb, 1978). These laboratory results represent a very small sample of the area covered by the confining beds and may not accurately reflect the areal vertical hydraulic conductivity. This is demonstrated by the results of an aquifer test which indicate the areal value of vertical hydraulic conductivity is $4 \times 10^{-2} \mathrm{ft} / \mathrm{d}$ or only about a thirty-fifth of the laboratory value of $1.37 \mathrm{ft} / \mathrm{d}$ reported for core hole number 38 (Grubb, 1977, table 1). Although the field value represents a more reliable estimate than the laboratory value 


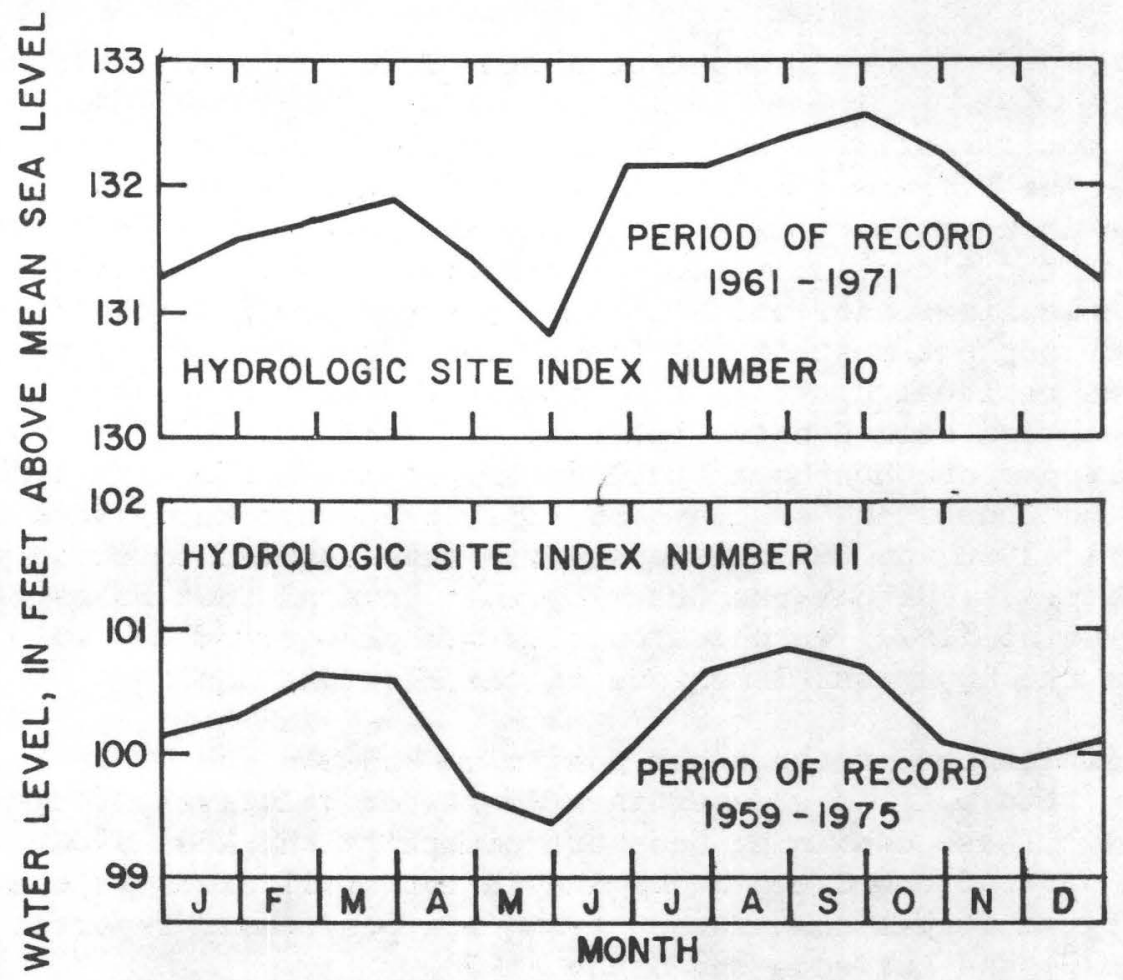

Figure 14.--Long-term average month-end water levels in the near-surface sand aquifer 


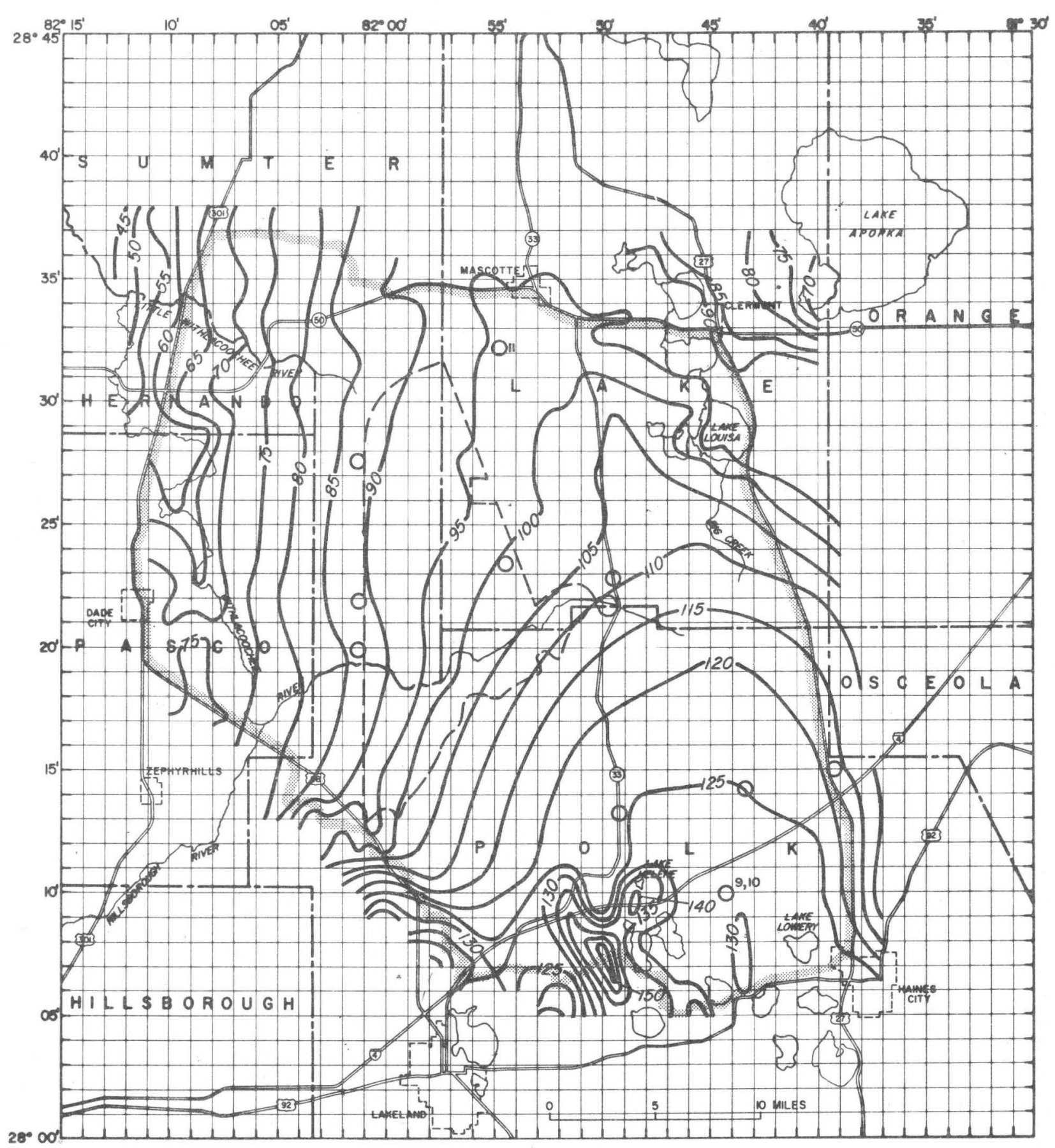

EXPLANATION

BOUNDARY OF GREEN SWAMP AREA

- FLOOD DETENTION AREA PROPOSED BY SOUTHWEST FLORIDA WATER MANAGEMENT DISTRICT
O OBSERVATION WELL

-90- POTENTIOMETRIC CONTOUR--SHOWS ALTITUDE AT WHICH WATER LEVEL WOULD HAVE STOOD IN TIGHTLY CASED WELLS. CONTOUR INTERVAL 5 FEET. DATUM IS MEAN SEA LEVEL.

Figure 15.--Estimated potentiometric surface of the near-surface sand aquifer, May 1977 




BOUNDARY OF GREEN SWAMP AREA

- FLOOD DETENTION AREA PROPOSED BY SOUTHWEST FLORIDA WATER MANAGEMENT DISTRICT

UPPER CONFINING BED THICKNESS, IN FEEר

$\begin{array}{ll}\square \text { LESS THAN } 5 & 10-19 \\ \because 3-9 & \text { GREATER THAN } 20\end{array}$

Figure 16.-Thickness of the confining beds overlying Floridan aquifer 
due to the larger area sampled, many such field tests are needed to increase the reliability of the estimates of this confining bed property for an area as large as the Green Swamp.

\section{Floridan Aquifer}

The Floridan aquifer has a potential for supplying large wantities of water from the green Swamp area because (1) the aquifer is present throughout the study area and all of central Florida; (2) it has a high transmissivity; (3) it has a large storage capacity; (4) recharge (leakage) from the overlying sand aquifer can be increased by pumping this aquifer; and (5) a relatively small volume of water is currently (1978) being withdrawn.

The Floridan aquifer is composed of middle Eocene to Oligocene limestone and dolomite and underlies the entire Green Swamp (Cooper and others, 1953, p. 17). Except for an area of about $24 \mathrm{mi}^{2}$ in the southwest part of the Green Swamp (Stewart, 1966, p. 88) it is the uppermost limestone aquifer in the area. The base of this aquifer is not well defined in the area due to a scarcity of hydrogeologic data at depths exceeding $600 \mathrm{ft}$ below land surface. Stewart (1966, p. 91) and Pride and others (1966, p. 79) place the base of this aquifer at the top of the Lake City Limestone or the lower part of the overlying Avon Park Limestone. This would, in general, indicate a thickness of about 1,000 ft in the Green Swamp area. A thickness of 1,500 to 2,000 $\mathrm{ft}$ is suggested by other workers. Knochenmus and Hughes (1976, p. 39) consider the top of the lower Eocene Oldsmar Limestone as the base of this aquifer in central Florida. Klein (1971) places the base of the potable water in the Floridan aquifer at 2,000 ft below land surface for a large part of central Florida. More information is needed from deep wells drilled specifically for the purpose of studying the lower part of the Floridan aquifer to help resolve questions regarding the thickness of this aquifer and the character of its lower boundary. It is generally believed the Floridan is underlain by dense and relatively impermeable middle or lower Eocene or older rocks.

The upper boundary of the Floridan aquifer is the overlying Miocene clay, residual clay, or post-Miocene sand. The top of this aquifer may be found at land surface or at depths greater than $200 \mathrm{ft}$ below land surface. It has been observed at land surface in only a few isolated locations in Sumter, Polk and Pasco Counties near the Withlacoochee River (Rutledge and Grubb, 1978). Depths to the top of this aquifer in excess of $200 \mathrm{ft}$ were reported for a few isolated areas along the Lake Wales Ridge on the eastern side of the Green Swamp (Pride and others, 1966, fig. 31). Generally, the aquifer is from 10 to $100 \mathrm{ft}$ below 1 and surface.

The transmissivity of this aquifer is highly variable within the Green Swamp. Pride and others (1966, p. 83) reported aquifer test values of about 2,900 to $94,000 \mathrm{ft}^{2} / \mathrm{d}$. They attributed this variability 
to areal and vertical variation in hydraulic conductivity of the aquifer and to unequal depths of aquifer penetration by the pumping wells. They recognized five different areal zones of constant hydraulic conductivity and made estimates of transmissivity for each area based on an assumed aquifer thickness of $1,000 \mathrm{ft}$.

There may be a tendency to overestimate transmissivity by assuming the hydraulic conductivity computed from an aquifer test applies to the total thickness of the aquifer when only a small fraction of the total thickness was penetrated by the control wells. Grubb (1977) found that 99 percent of the flow to a 200-ft-deep, 8-in. well came from the upper 30 percent of the Floridan aquifer at a south Lake County aquifer test site (fig. 2, site index number 12). The lower 70 percent of the aquifer penetrated at this site was a clayey limestone in the upper part of the Avon Park Limestone. Thus, a computed average hydraulic conductivity would give undue weight to the higher conductivity of the upper 30 percent of the open hole. The variability of the aquifer is illustrated by the following example. A 47-ft thick cavity was penetrated in a well at an aquifer test site in northwest Polk County (fig. 2, site index number 14) about $9 \mathrm{mi}$ south of the Lake County test site. The top of this cavity was $165 \mathrm{ft}$ below land surface in the upper part of the Avon Park Limestone. Just $60 \mathrm{ft}$ away, another well penetrated a clayey limestone to a depth of $200 \mathrm{ft}$ below land surface without encountering the cavity.

There is a large quantity of water stored in the Floridan aquifer because of its great thickness and a relatively high specific yield of 13 percent (average of 10 values reported by Stewart, 1966, p. 113). However, with the aquifer under artesian conditions, the change in storage per unit change in head (storage coefficient) in this aquifer is much less than that in the near-surface sand aquifer. Values of the storage coefficient for the Floridan aquifer are one-tenth to onethousandth of those for the unconfined sand aquifer (Pride and others, 1966, p. 83; Stewart, 1966, p. 114; and Grubb, 1977).

The potential for increasing the recharge to the Floridan aquifer from the overlying sand aquifer in the Green Swamp area was recognized by Stewart (1966, p. 119) and Pride and others (1966, p. 126). An increase in the downward gradient between the two aquifers, such as would be produced by pumping the Floridan aquifer, is necessary to realize this increase in recharge. The downward movement of water from the sand aquifer to the Floridan aquifer was demonstrated by an aquifer test (Grubb, written commun., 1978). A drawdown of $1.00 \mathrm{ft}$ (fig. 17) was observed in the sand aquifer at a distance of about $62 \mathrm{ft}$ from the pumping well which had been pumping $1,040 \mathrm{gal} / \mathrm{min}$ for $420 \mathrm{~min}$ from the Floridan aquifer. Drawdowns of 0.37 and $1.20 \mathrm{ft}$ were observed in the sand aquifer at distances of 300 and $62 \mathrm{ft}$, respectively (table 4), after 2,100 min $(35 \mathrm{~h})$ of pumping. 


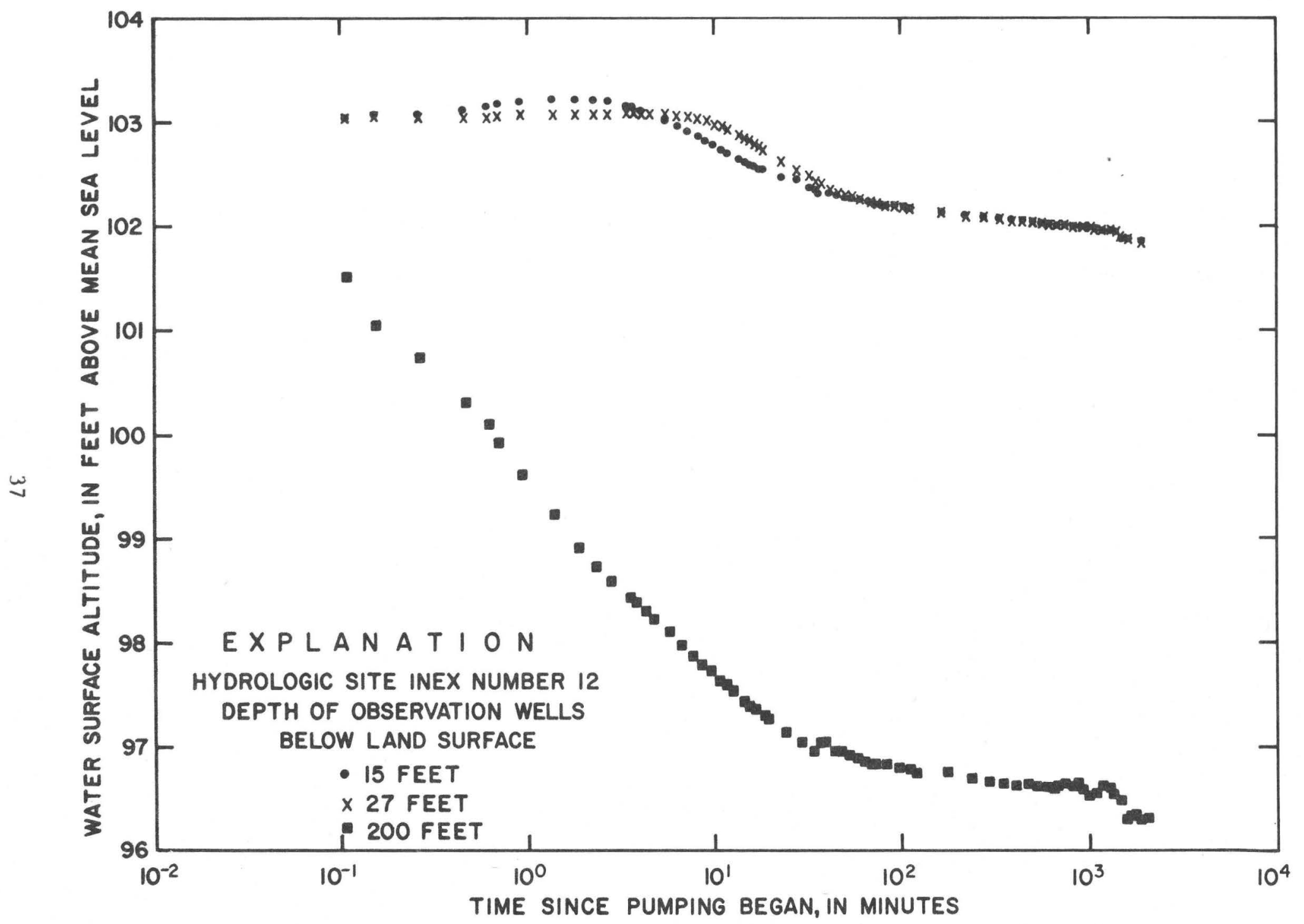

Figure 17.--Drawdown in near-surface sand aquifer and in Floridan aquifer due to pumping from the Floridan aquifer at 1,040 gallons per minute (observation wells about 62 feet from pumping we11) 
Table 4.--Drawdown in the near-surface sand aquifer after pumping the Floridan aquifer at an average rate of 1,040 gallons per minute

\begin{tabular}{ccc}
$\begin{array}{c}\text { Distance of observation } \\
\text { we11 from pump wel1 } \\
\text { (feet) }\end{array}$ & $\begin{array}{r}\text { Drawdown after } \\
\text { pumping } \begin{array}{c}420 \text { minutes } \\
(\text { feet })\end{array}\end{array}$ & $\begin{array}{r}\text { Drawdown after } \\
\text { pumping } 2,100 \text { minutes } \\
(\text { feet })\end{array}$ \\
\hline 30.8 & 1.02 & 1.19 \\
61.8 & 1.00 & 1.20 \\
100 & .66 & .91 \\
300 & .20 & .37
\end{tabular}




\section{Digita1 Prototype}

To assess withdrawal potential and consequent effects on water levels in the Green Swamp, a two-dimensional finite-difference groundwater flow model described by Pinder and Bredehoeft (1968) was utilized. Data collection was not geared for a three-dimensional model. The model uses the alternating-direction implicit procedure for solving the partial differential equation of ground-water flow in a confined aquifer in two dimensions. A uniform latitude-longitude grid of 1 min by $1 \mathrm{~min}(6,080$ by 5,400 ft) nodes was extended 1 to $5 \mathrm{mi}$ beyond the Green Swamp boundary and superimposed on the area (fig. 18).

\section{Floridan Aquifer}

The Floridan aquifer was modeled as a leaky, confined aquifer. The head distribution in the Floridan aquifer for May 1977 (fig. 9) was used as the initial head distribution in the model. The source of water to the Floridan aquifer is downward leakage through the confining bed. The difference between the head in the near-surface sand aquifer and the head in the Floridan aquifer is the driving force behind the leakage. The recharge rate of the modeled aquifer is proportional to this head difference and to the hydraulic conductivity of the confining bed, and is inversely proportional to the thickness of the confining bed. The head distribution in the sand aquifer shown in figure 15 was used by the model to calculate recharge. The relationship between the head distribution in the near-surface sand aquifer and the head distribution in the Floridan aquifer is shown in figure 19. These sections show that the largest head differences in the modeled area are along the northern and southern boundaries. Generally, the driving force in the eastern half of the Green Swamp is 2 to $3 \mathrm{ft}$ of head, while it is less than $0.5 \mathrm{ft}$ in the western half.

The two general types of boundary nodes in the model are no-flow nodes and constant-head nodes. No-flow nodes are located where the direction of ground-water flow is parallel to the boundary. There are two places on the northern boundary of the model that show no-flow nodes (fig. 18). Constant-head nodes are located where the direction of flow is out of the model. The north-south extending trough in the potentiometric surface at Dade City and the part of the model that exists near Lake Apopka spring are examples of this. Constant-head nodes were also used along the Withlacoochee River where it cuts into the Floridan aquifer and the sand aquifer is absent. Typical boundaries and the simulation devices used to represent them are shown in the hydrogeologic sections of figure 19. Both extremes of row 14 and the southern extreme of column 30 are constant-head nodes. There is outflow from the model to these nodes. The northern extreme of column 30 is a no-flow node. The hydrogeologic section of row 14 shows a reversal in the vertical head gradient at the Withlacoochee River. This represents a point of outflow from the model area. 


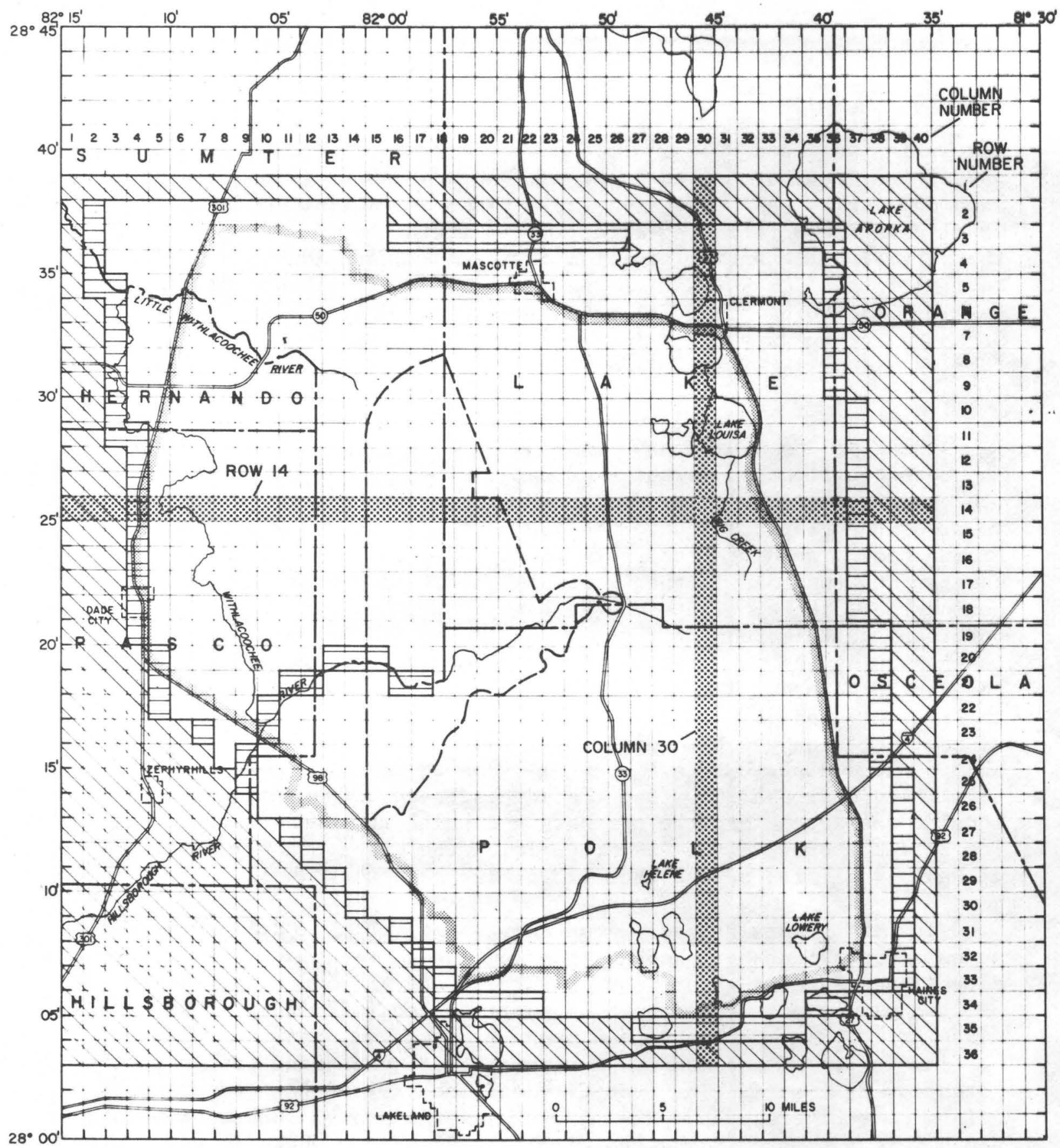

EXPLANATION

BOUNDARY OF GREEN
SWAMP AREA
FLOOD DETENTION AREA
PROPOSED BY SOUTHWEST
FLORIDA WATER MANAGE-
MENT DISTRICT

$\triangle$ NO-FLOW NODE

CONSTANT-HEAD NODE

Figure 18.--Finite-difference grid used for the digital ground-water flow model 


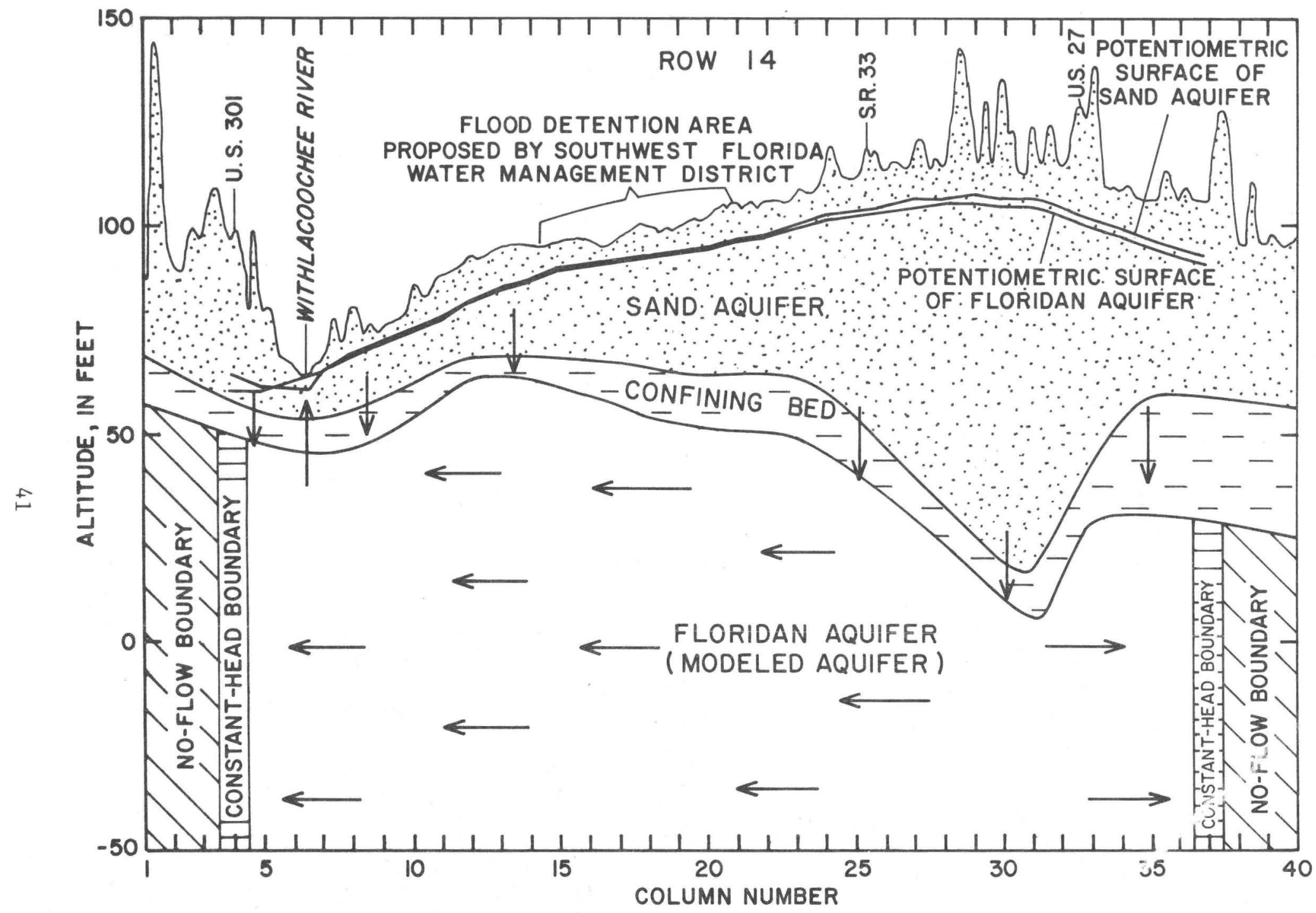

Figure 19.--Potentiometric surface of the sand aquifer, the potentiometric surface of the Floridan aquifer, and the flow in and out of the modeled aquifer 


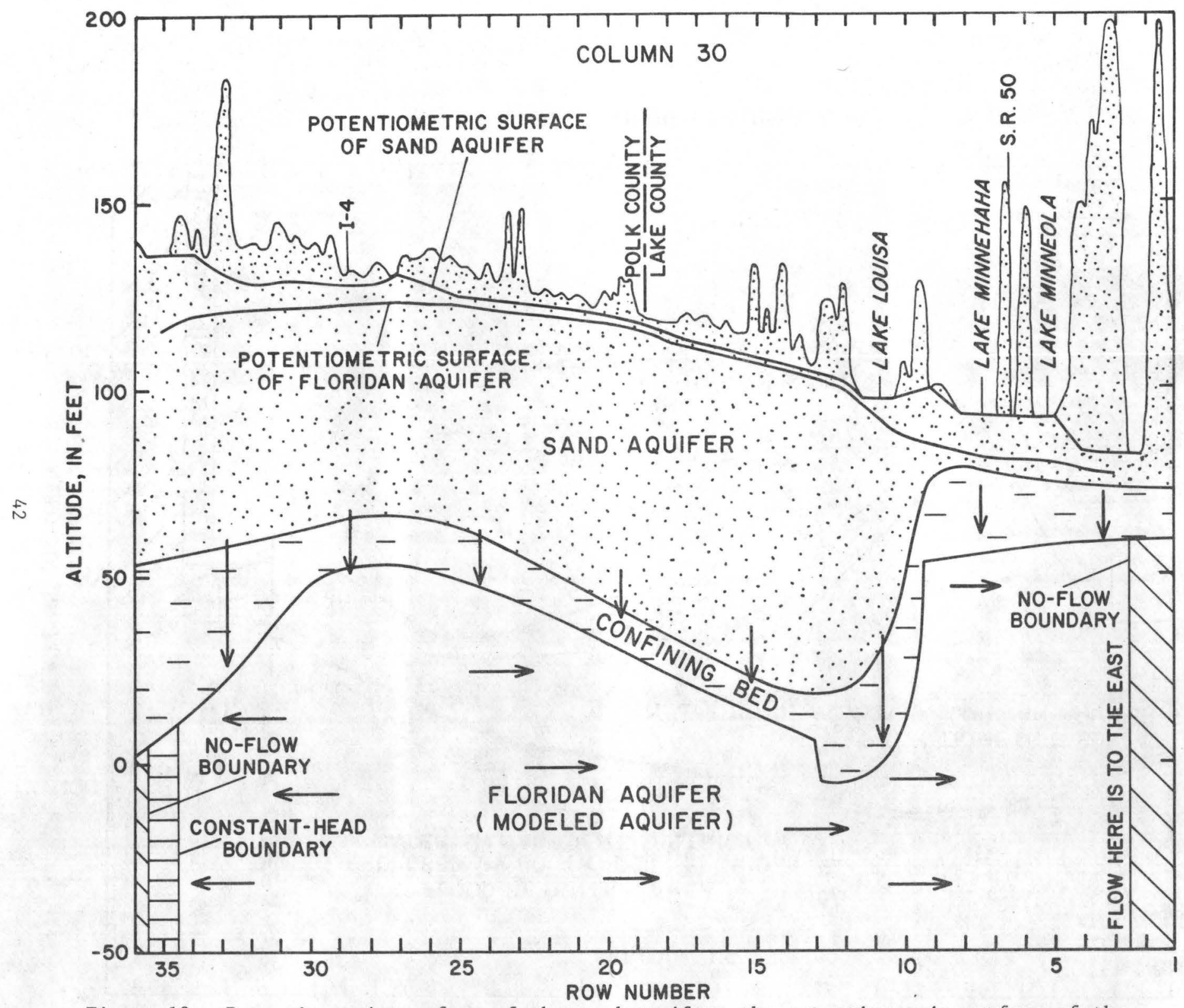

Figure 19.--Potentiometric surface of the sand aquifer, the potentiometric surface of the Floridan aquifer, and the flow in and out of the modeled aquifer (continued) 
For the purpose of this simulation, the May 1977 head distribution in the Floridan aquifer is assumed to be at steady state. This appears to be a good approximation because recharge to the sand aquifer is at a minimum, the annual low is in May (fig. 10), and the comparison of annual lows shows no persistent long-term downward trend (fig. 11). Also, the May 1977 potentiometric surface of the Floridan aquifer is the best defined surface for the period of record. Because a steadystate calibration is utilized, the storage coefficient does not enter into calculation.

The estimates of transmissivity of the Floridan aquifer that were initially used in the prototype were taken from Pride and others (1966, p. 85). These estimates were used to delineate the zones of various transmissivities shown in figure 20. Also shown in figure 20 are transmissivity values from the aquifer tests that were performed. The wide range in values of transmissivity is the result of unequal penetration by wells and by spacial variations in hydraulic conductivity.

\section{Upper Confining Beds}

The quantity of water that can move from the near-surface sand aquifer to the Floridan aquifer, at a given head differential, is dependent upon the thickness and vertical hydraulic conductivity of the upper confining beds. Upper confining bed thickness, from core hole drilling, was generalized areally into five values: $0,5,10,15$, and $25 \mathrm{ft}$. Confining bed thickness was generalized to zero in the outcrop areas of the Withlacoochee River and the Little Withlacoochee River. In areas where no clays were penetrated during the core drilling a confining bed thickness of $5 \mathrm{ft}$ was assumed to represent the bottom part of the sand aquifer which is the upper confining bed in those areas. Upper confining bed vertical hydraulic conductivity, from laboratory determinations, field observations, and aquifer test analyses was generalized areally into four values. The confining bed thickness and hydraulic conductivity results are shown in figures 21 and 22 .

\section{Calibration of Prototype}

Calibration of the model consisted generally of adjusting the upper confining bed hydraulic conductivity and the aquifer transmissivity within reasonable limits until the aquifer model simulated, as closely as possible, the actual aquifer. Each of the 22 subsequent model runs made the prototype resemble the actual hydrologic system more than the previous run. The main criterion used for this resemblance was the similarity of the initial head distribution to the head distribution in the model at steady state. An addition to the Pinder and Bredehoeft model that allowed the average error per node to be calculated made it possible to measure this similarity. The average error per node is the average of the absolute values of the head changes during the model run in all nodes. 


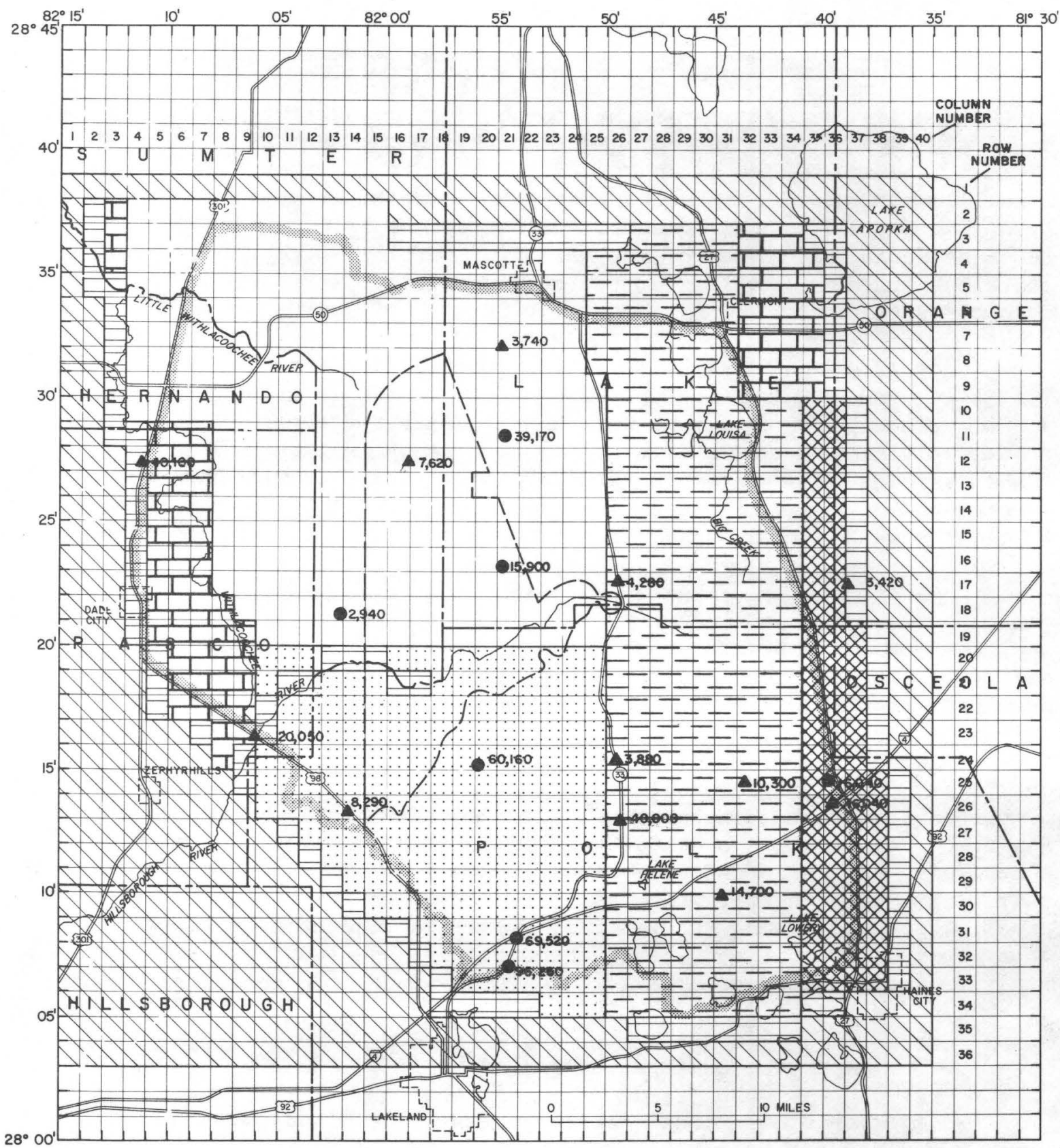

EXPLANATION

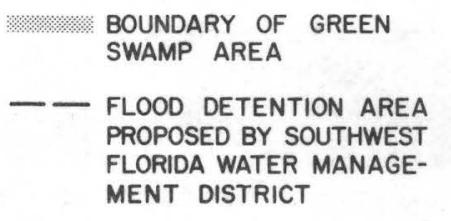

Y NO-FLOW E CONSTANTFLORIDA WATER MANAGEMENT DISTRICT

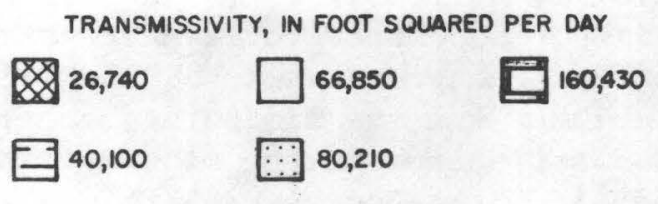

AQUIFER TEST SITE

\$3,880 TRANSMISSIVITY FROM PUMPING WELL

- 8,290 TRANSMISSIVITY FROM ONE OR MORE OBSERVATION WELLS

Figure 20.--Initial estimates of transmissivity of the Floridan aquifer 


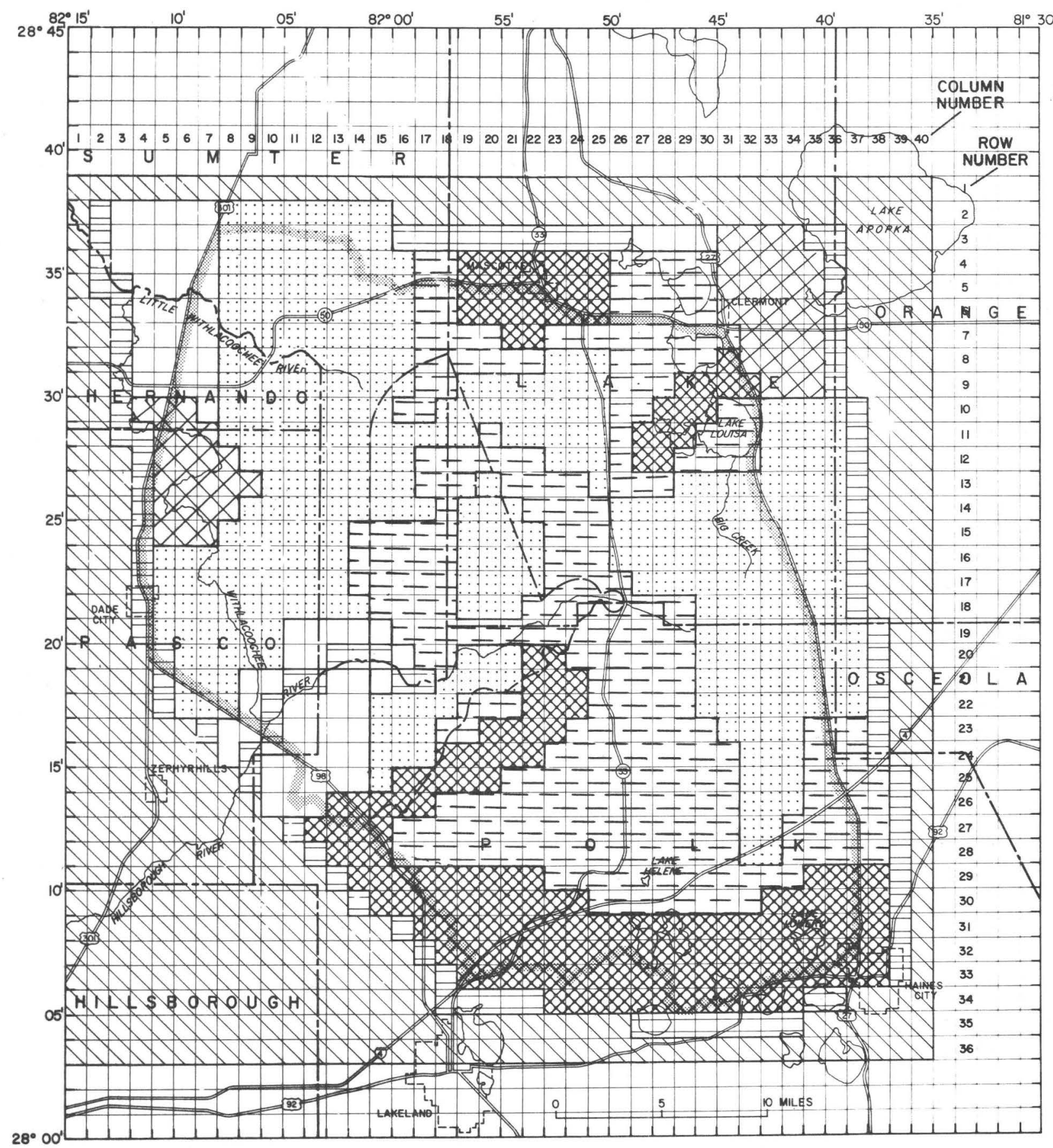

\section{EXPLANATION}

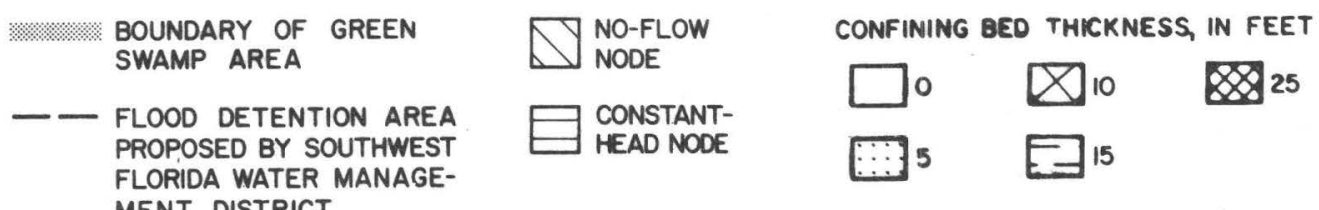

Figure 21.--Upper confining bed thickness used in the digital ground-water model 


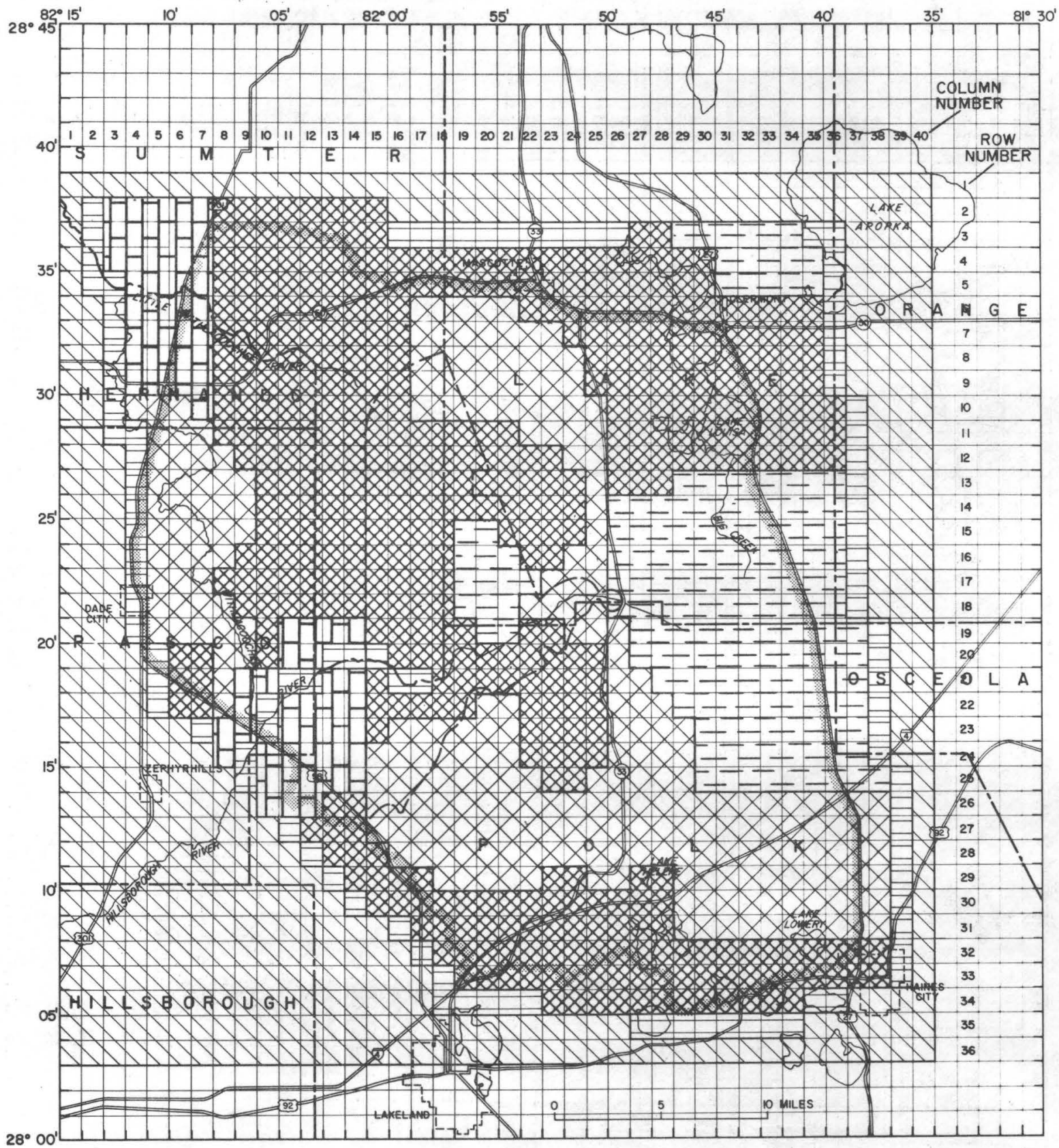

\section{EXPLANATION}

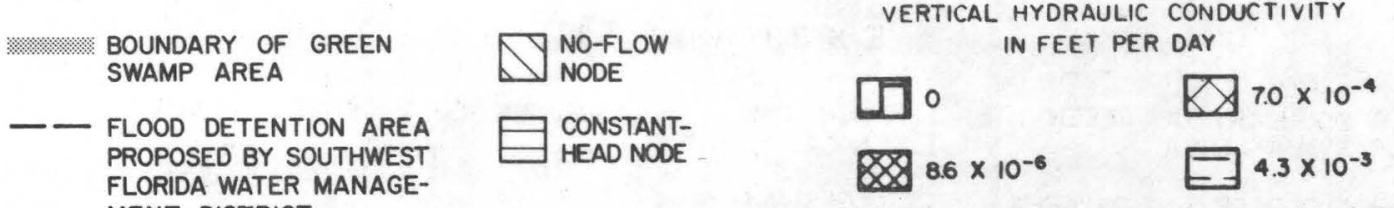

Figure 22.--Initial estimate of upper confining bed vertical hydraulic conductivity used in the digital ground-water model 
An average error per node of $0.64 \mathrm{ft}$ was attained after about 20 runs of the model. Figure 23 shows the decline in the average error per node and the adjustments in the flow regime that effected this decline. Most adjustments were on confining bed hydraulic conductivity or aquifer transmissivity in particular zones of the modeled area. If, in a particular zone, the simulated head was exhibiting drawdown, then the confining bed hydraulic conductivity would be increased or the aquifer transmissivity would be decreased. Conversely, if the simulated head was exhibiting a buildup, then the confining bed hydraulic conductivity would be decreased or the aquifer transmissivity would be increased.

Care was taken during these adjustments to keep these hydrologic parameters within reasonable limits. For example, before run 15, adjustments were made to correct for anomalous1y high recharge rates. This particular adjustment actually increased the average error per node temporarily (fig. 23).

Other adjustments included (1) increasing the extent of the sand aquifer in the western area of the mode1, (2) moving the western boundary of the model one to three nodes to the east so that it would coincide with the north-south potentiometric trough in the Dade City area, and (3) removing constant-head nodes along the Withlacoochee River downstream from the northeastern extreme of the Hillsborough River so that a line of constant-head nodes would not be located close to and parallel with the constant-head boundary.

A comparison of the model outflow with ground-water outflow estimates made previous to this study gave further support to the plausibility of the calibration. The total ground-water outflow from the Green Swamp area estimated by Pride and others (1966) is 1.8 in./yr during a period of high water levels and $2.6 \mathrm{in}$./yr during a period of low water levels. The calibrated digital model exhibited a total outflow from the modeled area (fig. 18) of $1.75 \mathrm{in.} / \mathrm{yr}$. The primary reason for this difference is that the transmissivity at the boundary of the Green Swamp area was generally lower in the calibrated model than the initial estimates of transmissivity.

The outflows of the modeled aquifer can be itemized for the various groups of constant-head nodes. Along the northern boundary near Mascotte, the ground-water outflow is $4.1 \mathrm{ft} / \mathrm{s}$. The total along the eastern boundary is $74 \mathrm{ft}^{3} / \mathrm{s}$ and along the southern boundary between Haines City and Zephyrhills, $29 \mathrm{ft}^{3} / \mathrm{s}$. The remaining western boundary takes $39 \mathrm{ft}^{3} / \mathrm{s}$. The pickup received by the Withlacoochee River from the prototype aquifer is $7.8 \mathrm{ft}^{3} / \mathrm{s}--4.0 \mathrm{ft}^{3} / \mathrm{s}$ of this pickup occurs at constant-head nodes. The remainder occurs along that part of the Withlacoochee which is downstream of the Hillsborough River overflow. It is along this reach of the Withlacoochee River that the head gradient is upward. The $4.0 \mathrm{ft}^{3} / \mathrm{s}$ ground-water discharge at constant-head nodes along the Withlacoochee is approximately onetenth the discharge at the Cumpressco gage. 


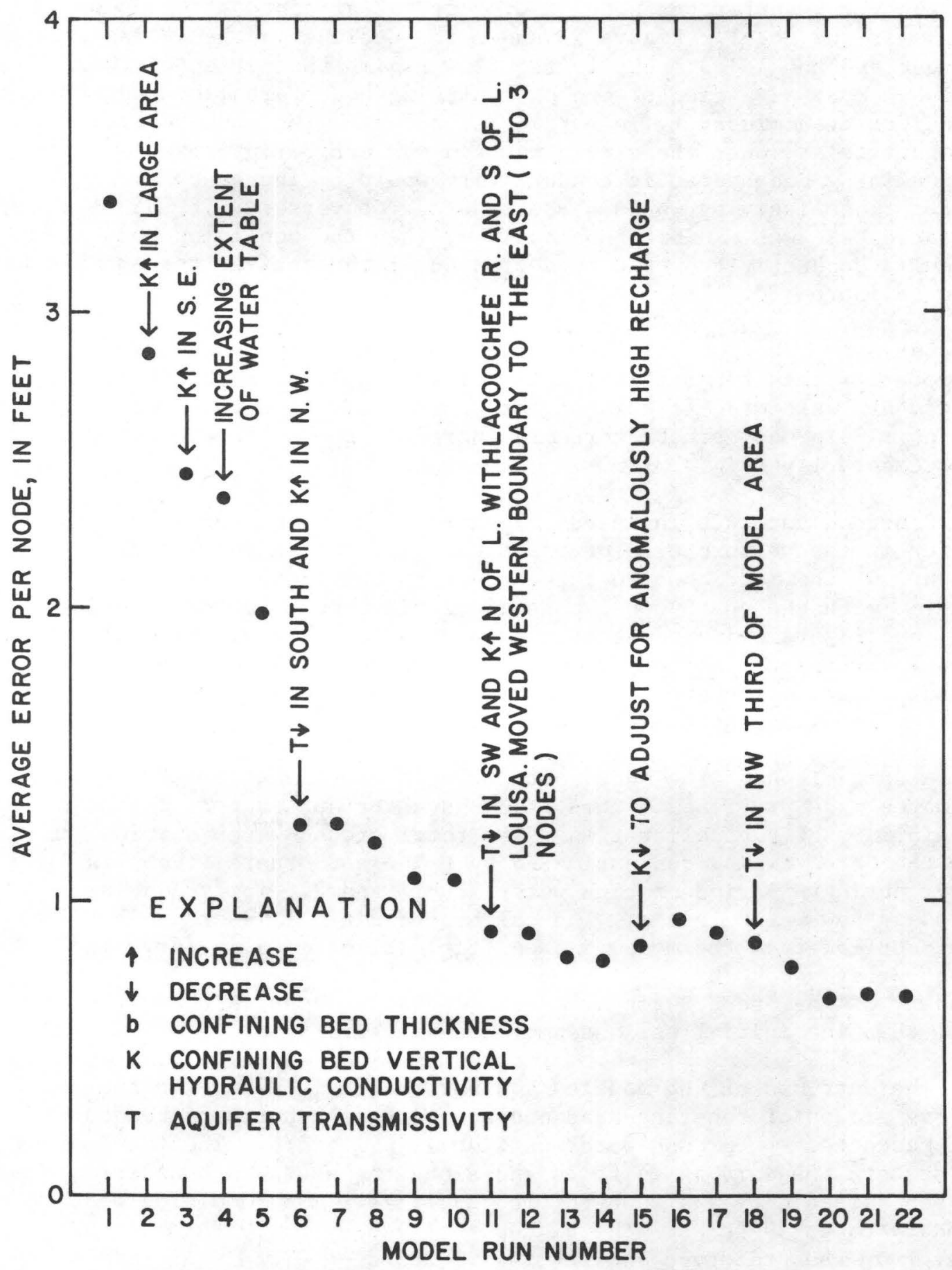

Figure 23.--Average error per node for various calibration runs of the digital model. Hydrologic parameter adjustments made before individual model runs are indicated 
The final calibrated potentiometric surface is compared to the initial (May 1977) potentiometric surface in figures 24 and 25 . The final calibrated potentiometric surface is the head distribution in the twenty-second run of the prototype at steady state. Tile illustrations show that zones of slight buildup and drawdown exis throughout the model area. The average error per node in the final $x$ in was $0.68 \mathrm{ft}$ and the maximum node error was $3.39 \mathrm{ft}$. The hydrologic sections of figure 25 show the potentiometric surface of the calitrated model changes in a continuous manner, unlike the initial potentiome ric surface. The reason for this is the head distribution has been made to conform with the ground-water flow equation. For this reason, the head distribution of the calibrated model may actually be more realistic than that of the initial head distribution because the initial head distribution was developed from only 21 wells spread over the entire study area.

The adjustments made during calibration of the model resulted in the following major conceptual changes in the initial ground-water flow system: (1) the area covered by the sand aquifer was extended northwestward from the Sumter-Pasco County line to include an additional area of about $110 \mathrm{mi}^{2}$; (2) the initial estimated aquifer transmissivity was reduced by at least 60 percent over about 70 percent of the model area; and (3) the initial estimated values of upper confining bed hydraulic conductivity were increased from about 6 to 100 times over about one-third of the model area. The extension of the area covered by the sand aquifer was based mainly on core from one test hole which had $30 \mathrm{ft}$ of surficial sand. The change in aquifer transmissivity brought these values into closer agreement with aquifer test results in the area (fig. 26). The initial estimates of confining bed vertical hydraulic conductivity could have been anomalously low because of the discontinuous nature of the lithology of the area and because of the large errors which are inherent in laboratory determinations of hydraulic conductivity. The final values of vertical hydraulic conductivity in the southern part of the study area are in close agreement with the values found by Wilson (1977, p. 19) in the adjoining area to the south.

Figure 26 shows the distribution of aquifer transmissivity of the final calibrated model. The area having a transmissivity of 40,100 $\mathrm{ft}^{2} / \mathrm{d}$ has been expanded to include the northwestern third of the modeled area. The transmissivity has been increased substantially in the Dade City area and in the area between Lake Louisa and Lake Apopka. It has been decreased along the southeastern boundary of the modeled area. The high value of transmissivity in the Dade City area is supported by determinations made by C. H. Tibbals (oral commun., 1978). A measurement of $30 \mathrm{ft}^{3} / \mathrm{s}$ flow at Lake Apopka Spring (P. W. Bush, oral commun., 1976) indicates a very high value of transmissivity in the area. The lower values of transmissivity along the southeastern boundary probably result from sand-filled fractures (Pride and others, 1966). 


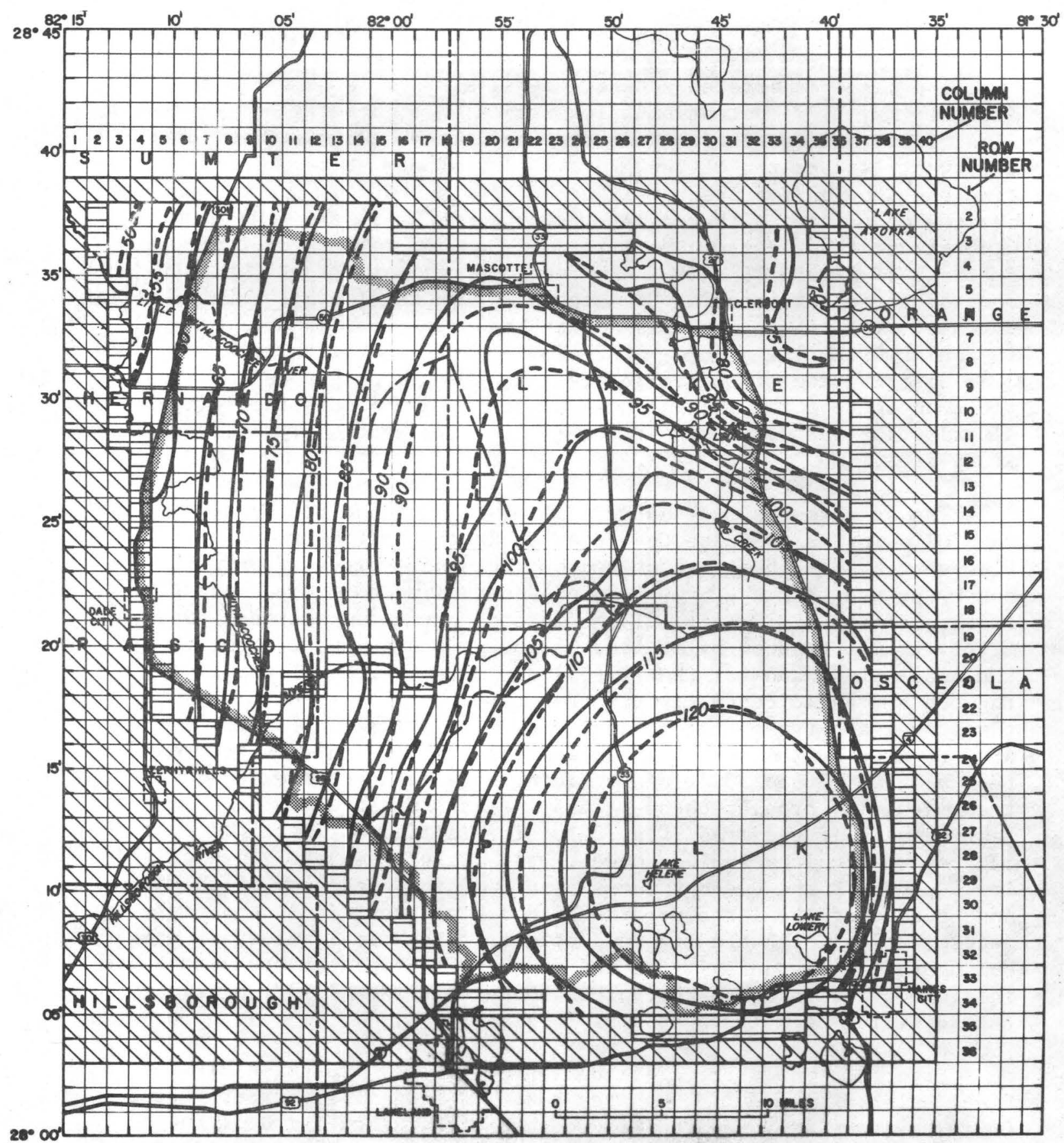

\section{EXPLANATION}
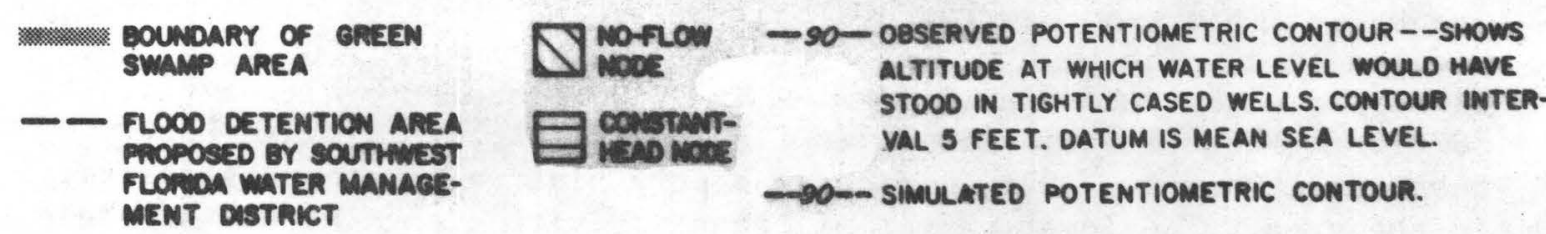

$\rightarrow 0-$ SIMULATEO POTENTIOMETRIC CONTOUR.

Figure 24.--The May 1977 potentiometric surface of the Floridan aquifer compared to the potentiometric surface from the calibrated model 

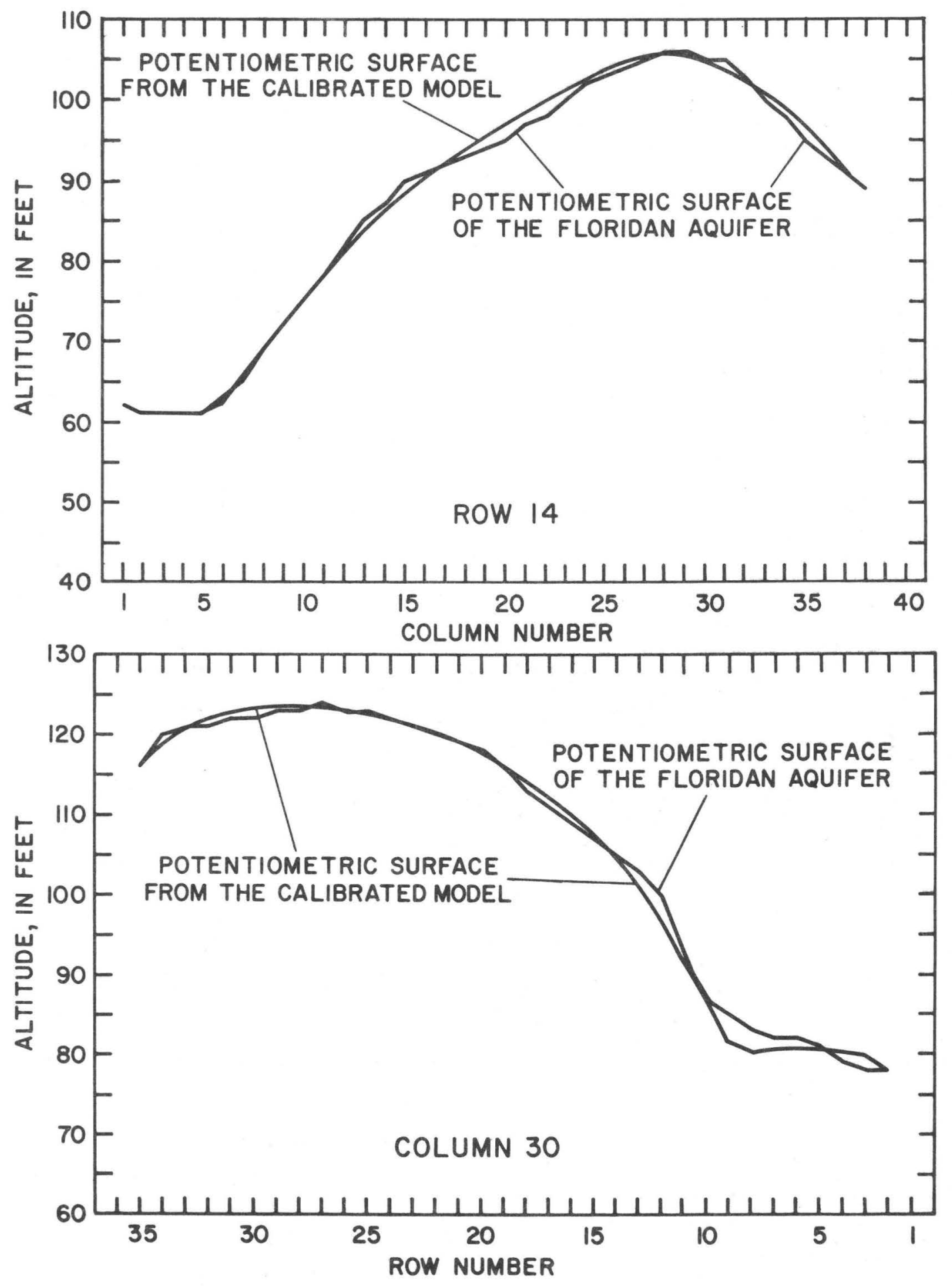

Figure 25.--Comparison of the potentiometric surface of the Floridan aquifer in May 1977 to that generated by the calibrated mode1 




EXPLANATION

BOUNDARY OF GREEN SWAMP AREA

- FLOOD DETENTION AREA PROPOSED BY SOUTHWEST FLORIDA WATER MANAGEMENT DISTRICT
NO-FLOW NODE

CONSTANTHEAD NODE
TRANSMISSIVITY, IN FOOT SQUARED PER DAY

II 13,370

$\square 40,100$

\#259,200

26,740
ㅈ. 80,210

[] 864,000

AOUIFER TEST SITE

$\triangle 14,700$ TRANSMISSIVITY FROM PUMPING WELL

15,900 TRANSMISSIVITY FROM ONE OR MORE

Figure 26. --Distribution of Floridan aquifer transmissivity in the calibrated model 
Figure 27 shows the distribution of upper confining bed vertical hydraulic conductivity in the final calibrated model. In achieving calibration, there were substantial increases in this hydrologic parameter, including a change from 0 to $4.3 \times 10^{-4} \mathrm{ft} / \mathrm{d}$ in the western extremes of the Withlacoochee and the Little Withlacoochee Rivers.

\section{Sensitivity of Calibration}

An unknown degree of uncertainty is inherent in the data used as input for the digital prototype. This problem is being addressed (Cooley, 1977), but commonly accepted methods for evaluating the reliability of steady-state ground-water flow models have not been developed. Therefore, a simple uniform change in one parameter from each distinct part of the flow system was used to demonstrate the sensitivity of the calibrated prototype to the input data. The input parameters selected were the position of the potentiometric surface of the sand aquifer, the vertical hydraulic conductivity of the confining beds, and the transmissivity of the aquifer.

Potentiometric surface of sand aquifer.--A uniform 1 percent decrease in the altitude of the potentiometric surface of the sand aquifer resulted in a $0.58-\mathrm{ft}$ increase in the average error per node and a 1.19-ft increase in the maximum node error. A uniform 1 percent increase in the altitude of the potentiometric surface of the sand aquifer resulted in a $0.65-\mathrm{ft}$ increase in the average error per node and a 1.10-ft increase in the maximum node error. Figure 28 is a hydrologic cross section showing the calibrated potentiometric surface and the potentiometric surface after a 1 percent increase and a 1 percent decrease in the sand aquifer potentiometric surface.

Floridan aquifer transmissivity.--A uniform 50 percent decrease in the transmissivity of the aquifer resulted in an increase in the average error per node of $0.81 \mathrm{ft}$ and an increase in the maximum node error of $3.12 \mathrm{ft}$. A uniform 50 percent increase in the transmissivity of the aquifer resulted in the average error per node of $0.53 \mathrm{ft}$ and an increase in the maximum node error of $1.74 \mathrm{ft}$. Figure 29 shows a hydrologic cross section of these changes.

Confining bed hydraulic conductivity.--A uniform 50 percent decrease in the vertical hydraulic conductivity of the confining bed resulted in a $1.00-\mathrm{ft}$ increase in the average error per node and a 3.02-ft increase in the maximum node error. A uniform 50 percent increase in the vertical hydraulic conductivity resulted in a $0.52-\mathrm{ft}$ increase in the average error per node and a 1.83-ft increase in the maximum node error. Figure 29 shows a hydrologic cross section of these changes.

Significance of calibration sensitivity.--To determine the relative potential for error of each of these hydrologic parameters, the uncertainty of the estimates of each must be considered in addition to the sensitivity of the model to each hydrologic parameter. A 1 percent 


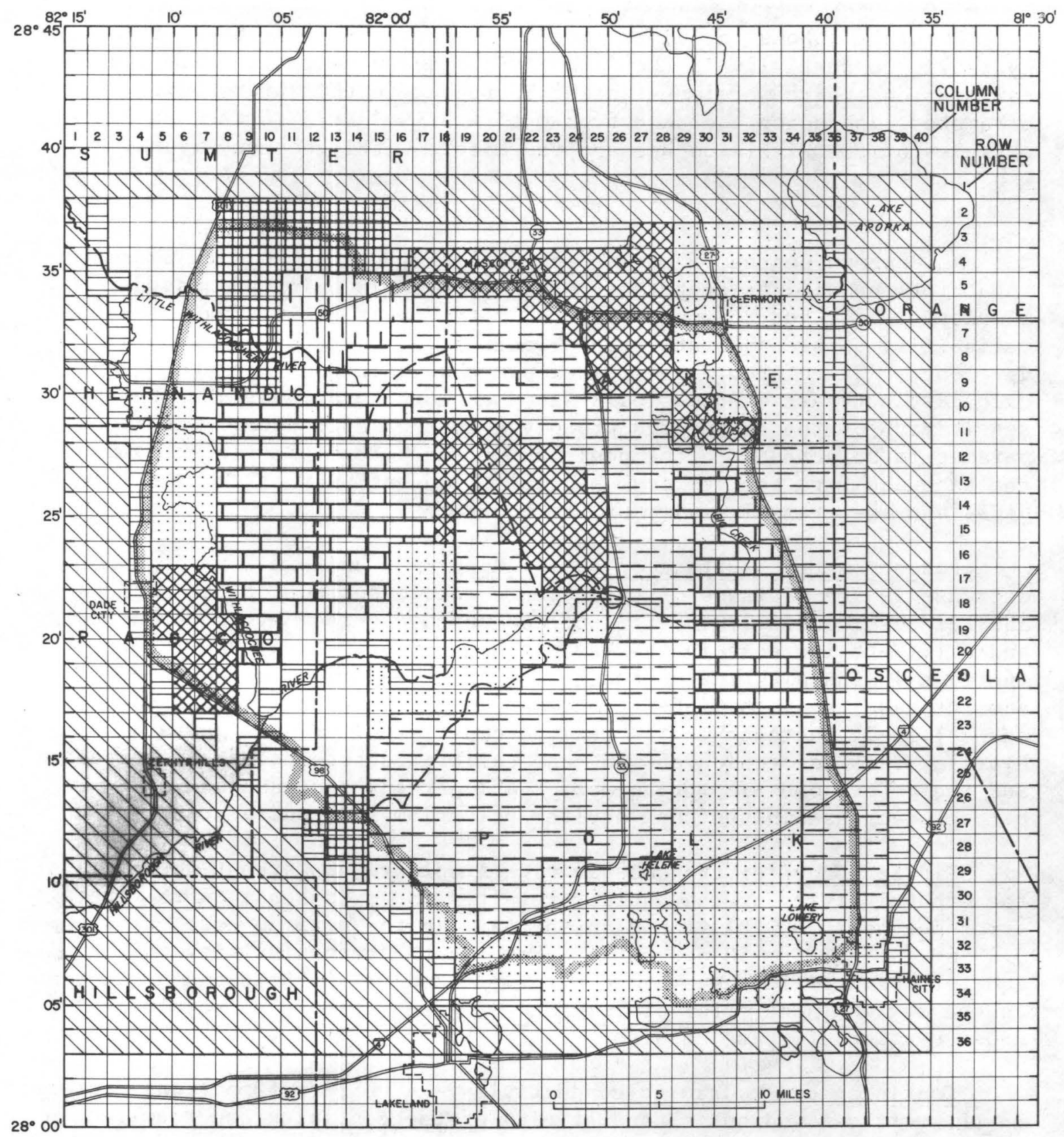

\section{EXPLANATION}

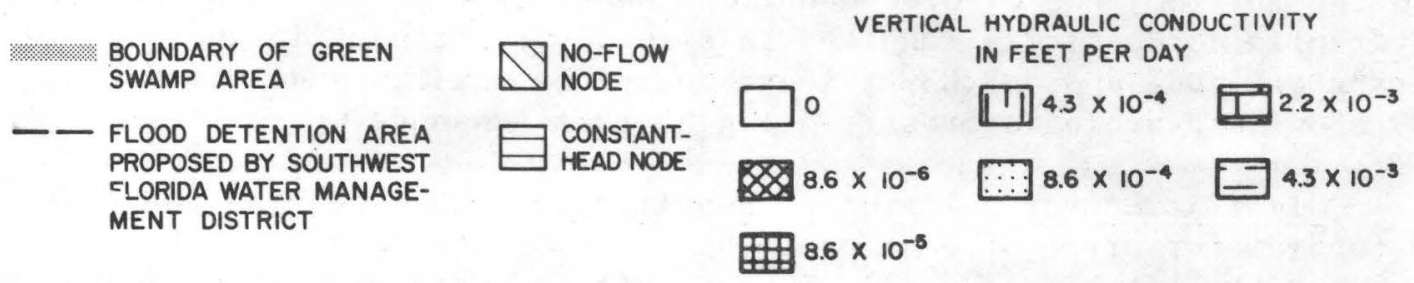

Figure 27.--Distribution of upper confining bed vertical hydraulic conductivity in the calibrated mode 1 


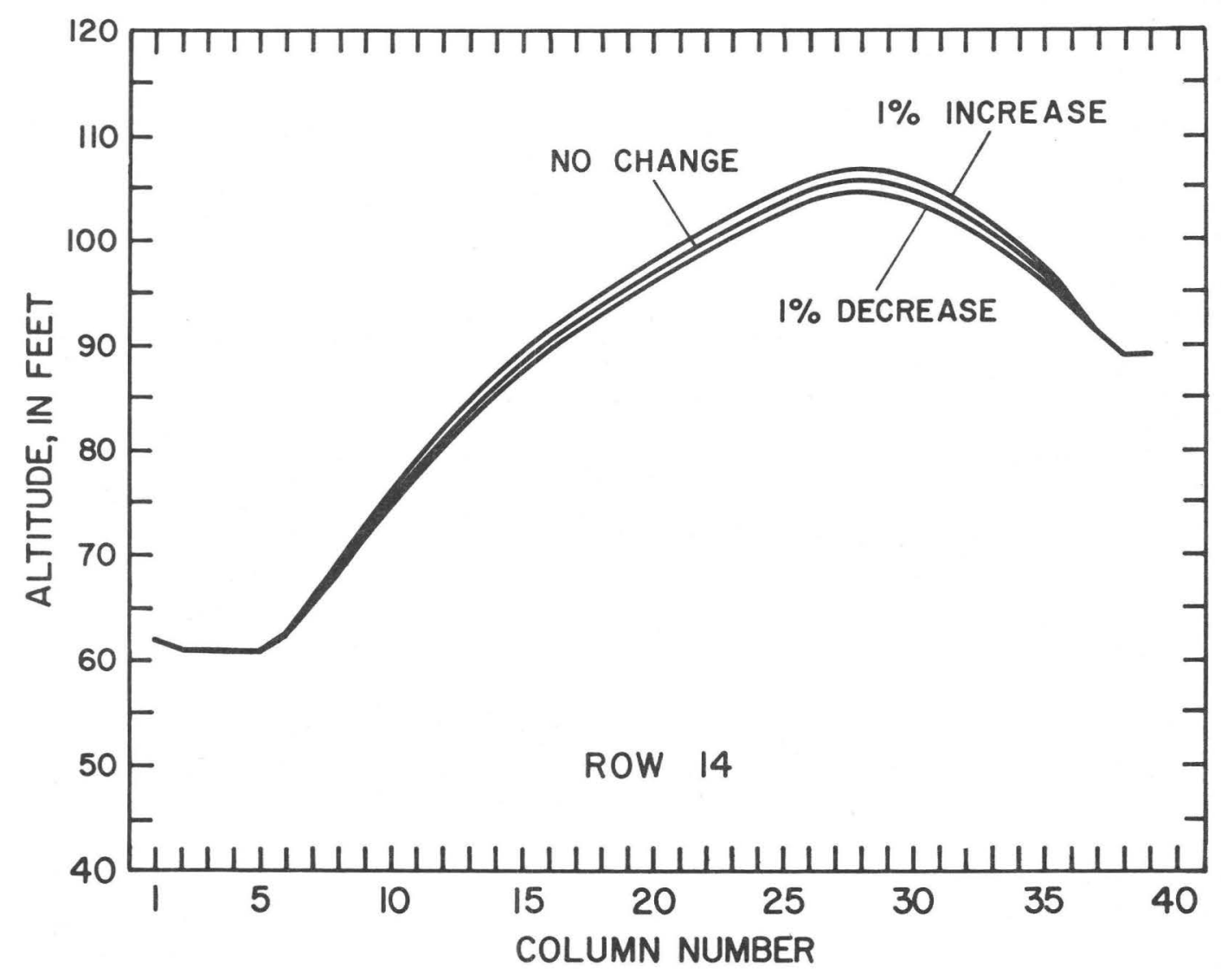

Figure 28.--The effects of a 1 percent increase and a 1 percent decrease in the altitude of the potentiometric surface of the sand aquifer on the calibrated potentiometric surface of the Floridan aquifer 

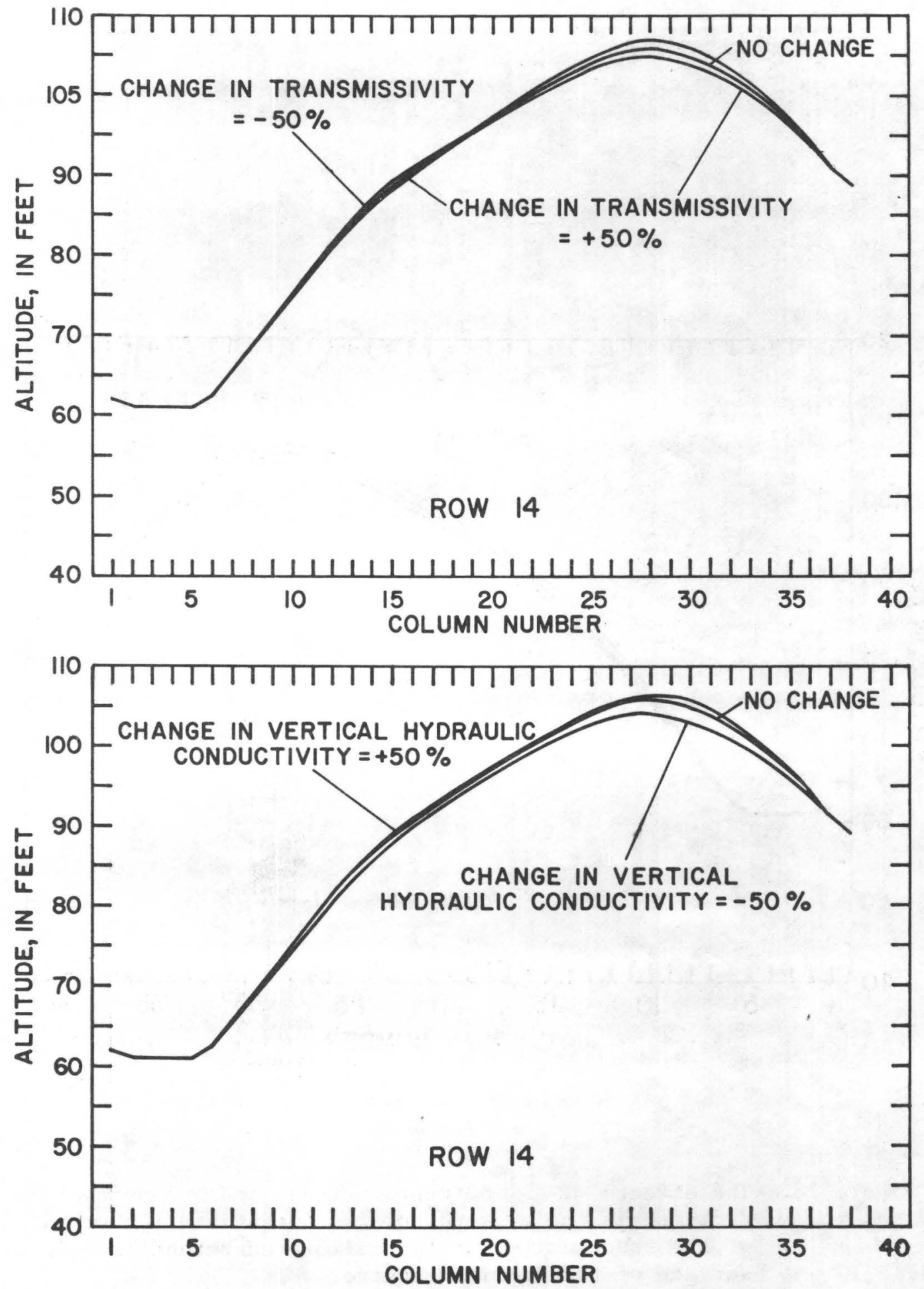

Figure 29.--The effects of a 50 percent increase and a 50 percent decrease in aquifer transmissivity and upper confining bed hydraulic conductivity on the calibrated potentiometric surface of the Floridan aquifer 
change in the water-table head, a 50 percent change in the confining bed hydraulic conductivity, and a 50 percent change in the aquifer transmissivity create approximately the same error in the calibration. A 50 percent change in confining bed hydraulic conductivity may actually be considerably less than the amount of uncertainty of the estimates of this hydrologic parameter, while the amount of uncertainty associated with the other two hydrologic parameters is approximately equal to the changes given above. For this reason, it is apparent the most significant source of error to this model is the hydraulic conductivity of the confining bed.

To increase the confidence of the calibrated model, the greatest returns would result from establishing more accuracy on the determinations of hydraulic conductivity of the confining bed. This would necessitate many aquifer tests designed to determine confining bed hydraulic conductivity. Of secondary importance is increasing the accuracy of the potentiometric surface of the sand aquifer. This necessitates more sand aquifer wells--especially adjacent to existing Floridan aquifer wells.

A decrease in the hydraulic conductivity of the confining bed results in twice the change in the aquifer head as does an increase of equal magnitude (fig. 29). For this reason, it is more likely the hydraulic conductivity of the model is too high rather than too low. Also, it is more likely that the sand-aquifer potentiometric surface is too low than too high because of the upward boundary caused by the land surface.

\section{Effect of Large-Scale Withdrawals}

Probably the most obvious effect of large scale ground-water withdrawals from the Floridan aquifer in the Green Swamp area would be the lowering of the potentiometric surface of the Floridan aquifer. However, there will be other effects such as increasing recharge (leakage) to the Floridan aquifer, reducing ground-water outflow from the Floridan aquifer, increasing the range of fluctuation of the potentiometric surface of the sand aquifer, reducing streamflow, reducing the head in the sand aquifer, draining of marsh areas, changing vegetation patterns, increasing sinkhole occurrence, and perhaps reducing evapotranspiration in areas of large drawdown in the sand aquifer.

\section{Floridan Aquifer}

The effects of ground-water withdrawals on the potentiometric surface of the Floridan aquifer were examined for several well-field arrangements by simulating pumpage with the calibrated model. Each well field was represented by a group of six uniformly spaced pumping nodes with a simulated pumping rate of about $15 \mathrm{Mgal} / \mathrm{d}$ per node. This pumping rate from the 1-minute node is equivalent to four wells per square mile, each pumping at about 2,200 gal/min. Well fields were 
located near the proposed flood detention area and far enough away from the boundaries of the model area so that the drawdown beyond the Green Swamp area boundary would be small.

The volume of leakage from the overlying sand aquifer was limited to a maximum of $20 \mathrm{in./yr}$. This was accomplished by calculating the vertical gradient required to move $20 \mathrm{in}$. of water, on an annual basis, across the upper confining bed in each node and then adjusting the top of the Floridan aquifer altitude in the prototype. Thus, the leakage rate was held constant when the drawdown in the Floridan aquifer reached the altitude of the top of the Floridan aquifer as adjusted. The maximum leakage rate of $20 \mathrm{in}$. was chosen because it is equal to the sum of the maximum local runoff and the present ground-water outflow.

As ground-water withdrawal increases in the western part of the Green Swamp and runoff is diverted to ground-water recharge the Withlacoochee River probably ceases to function as the constant source specified in the calibrated prototype from the Hillsborough River overflow upstream to the Sumter-Polk County line. Therefore, the nine constant-head nodes which represent this reach of the Withlacoochee were removed from the prototype when well fields were simulated in this part of the Green Swamp.

Six pumping centers.--The effects of pumping about $91 \mathrm{Mgal} / \mathrm{d}$ on the potentiometric surface of the Floridan aquifer are shown in figure 30 . The potentiometric surface was lowered $1 \mathrm{ft}$ or more over an area of about $100 \mathrm{mi}^{2}$ with a maximum drawdown of $32 \mathrm{ft}$ at one pumping node. The drawdown in the affected area is equivalent to an average of about $2 \mathrm{ft}$ of drawdown throughout the entire area. This withdrawal from the Floridan aquifer was simulated by six pumping nodes located about $2 \mathrm{mi}$ apart along the eastern side of the proposed flood detention area.

Reduction in ground-water outflow from the Green Swamp is relatively small because of the location of the pumping near the center of the Green Swamp and a relatively large increase in recharge to the Floridan aquifer in the vicinity of the pumping wells (table 5).

Twelve pumping centers.--The effects of pumping an additional 91 $\mathrm{Mgal} / \mathrm{d}$ on the potentiometric surface of the Floridan aquifer is shown in figure 31. The potentiometric surface was lowered $1 \mathrm{ft}$ or more over an area of about $500 \mathrm{mi}^{2}$ with a maximum drawdown of $34 \mathrm{ft}$ at one pumping node. The 120-ft contour line disappeared. The drawdown in the affected area was equivalent to an average drawdown of about $4 \mathrm{ft}$ over the entire model area. This pumping was simulated by 12 pumping nodes; the 6 described previously along the eastern side of the proposed flood detention area and 6 along a north-south line beginning about $1 \frac{1}{2}$ mi southwest of Lake Louisa and ending near the center of the dome on the potentiometric surface about $2 \mathrm{mi}$ northeast of Lake Helene. 


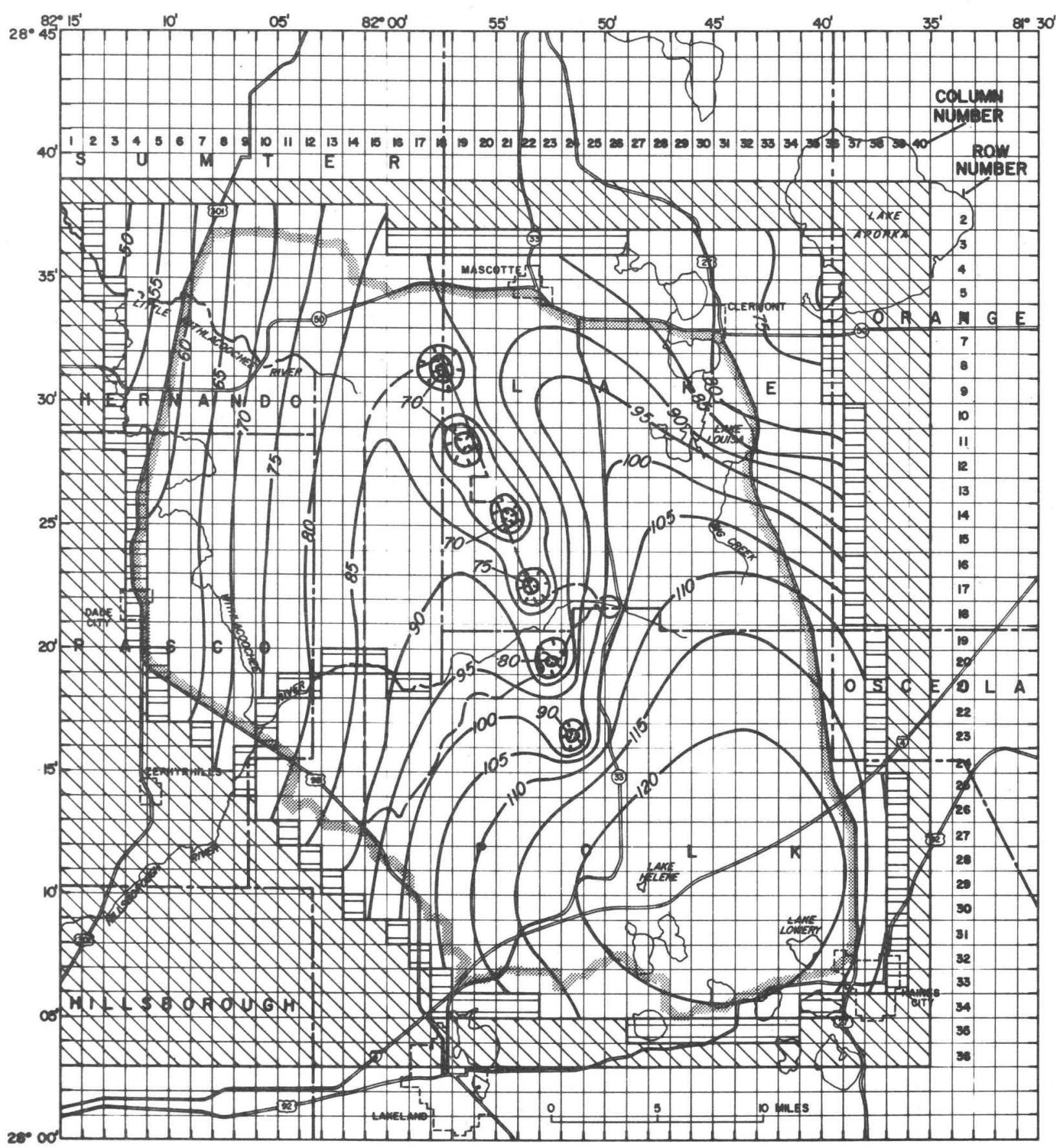

\section{EXPLANATION}

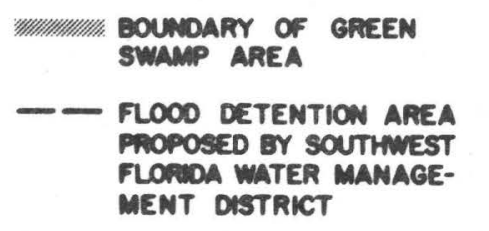

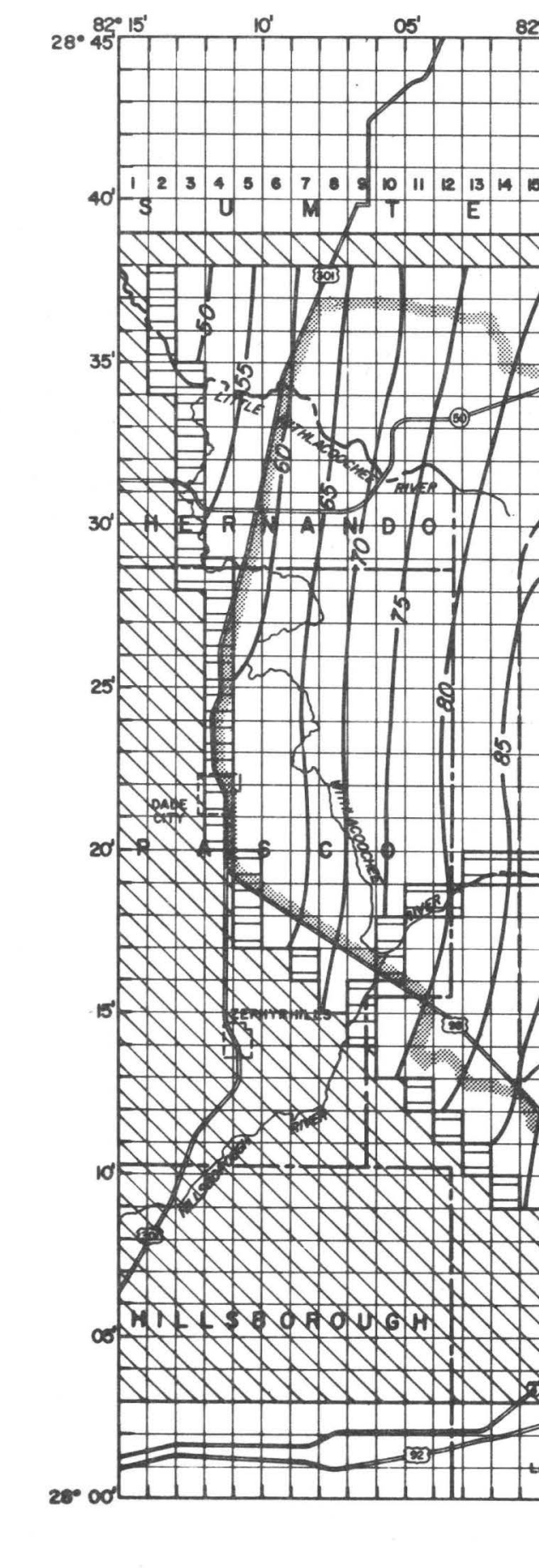

7 NO-FLOW NOOE INTERVAL 5 FEET. DATUM IS MEAN SEA LEVEL.

\section{E CONSTANT-}

Figure 30.--The simulated effects of pumping about 91 million gallons per day on the potentiometric surface of the Floridan aquifer 
Table 5.-- Steady-state inflow and outflow for various conditions simulated by the digital model

\begin{tabular}{|c|c|c|c|c|}
\hline Simulated condition & $\begin{array}{l}\text { Inflow to } \\
\text { Constant } \\
\text { head } \\
\text { (million } \\
\text { gallons } \\
\text { per day }\end{array}$ & $\begin{array}{l}\text { a modeled } \\
\text { Downward } \\
\text { leakage } \\
\text { (million } \\
\text { gallons } \\
\text { per day }\end{array}$ & $\begin{array}{l}\text { Pumpage } \\
\text { (million } \\
\text { gallons } \\
\text { per day }\end{array}$ & $\begin{array}{l}\text { modeled } \\
\text { Constant } \\
\text { head } \\
\text { (million } \\
\text { gallons } \\
\text { per day }\end{array}$ \\
\hline No pumping & 22 & 99 & 0 & 120 \\
\hline Six pumping centers & 24 & 185 & 91 & 116 \\
\hline Twelve pumping centers & 25 & 271 & 183 & 111 \\
\hline Eighteen pumping centers & 25 & 342 & 274 & 92 \\
\hline $\begin{array}{l}\text { Eighteen pumping centers with a } \\
\text { conservation pool in the } \\
\text { proposed flood detention area }\end{array}$ & 22 & 349 & 274 & 96 \\
\hline
\end{tabular}




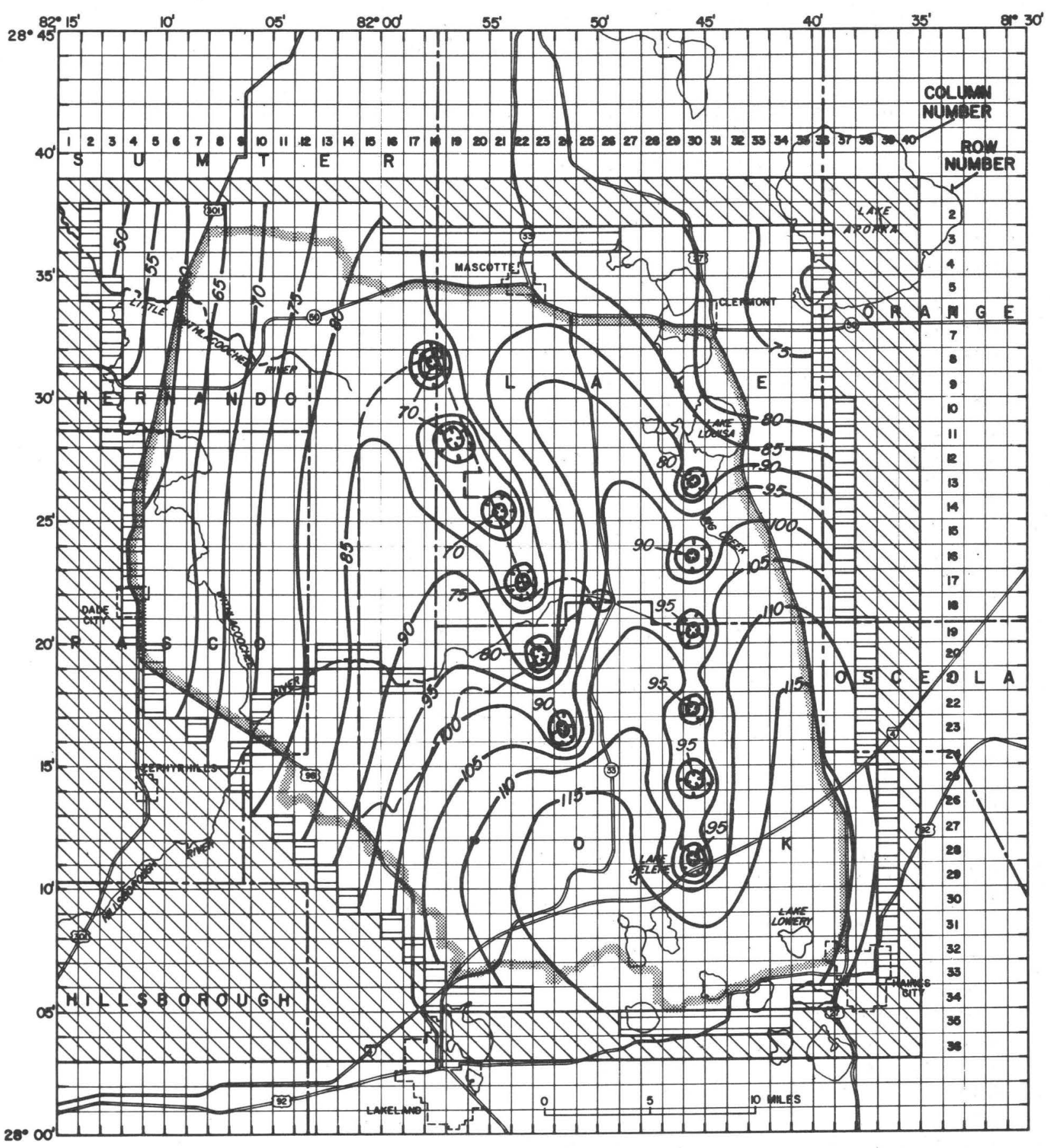

EXPLANATION

BOUNDARY OF GREEN SWAMP AREA

- FLOOO DETENTION AREA PROPOSED BY SOUTHWEST FLORIOA WATER MANAGEMENT DISTRICT
NOFLOW
NODE CONSTANT-

HEAD NOOE

Figure 31.--Simulated effects of pumping about 183 million gallons per day on the potentiometric surface of the Floridan aquifer 
A reduction in ground-water outflow along the eastern boundary of the Green Swamp is indicated by the ground-water divide which developed parallel to the easternmost line of wells and almost coincident with the Green Swamp boundary. The reduction in ground-water outflow is smaller than the increase in recharge to the Floridan aquifer (table 5).

Eighteen pumping centers.--The effects of pumping about $274 \mathrm{Mgal} / \mathrm{d}$ on the potentiometric surface of the Floridan aquifer are shown in figures 32 and 33. The potentiometric surface was lowered $1 \mathrm{ft}$ or more over an area of about $700 \mathrm{mi}^{2}$. The maximum drawdown was $38 \mathrm{ft}$ in one of the pumping nodes near the center of the Green Swamp and the average drawdown was equivalent to $6 \mathrm{ft}$ for the entire model area. This pumping was simulated by the 12 pumping nodes described previously plus 6 additional pumping nodes along a north-south line on the west side of the flood detention area.

An additional reduction in ground-water outflow is indicated along the western boundary of the Green Swamp by the reduction in gradient from the Sumter-Pasco County line to the western boundary of the Green Swamp. However, the increase in recharge to the Floridan aquifer is still the major source of water for the increased withdrawal (table 5).

Figure 34 shows the nodes that exhibited the maximum recharge (20 in./yr) with 18 pumping centers. Also shown in figure 34 is the part of the Withlacoochee basin between the Eva gage and the Cumpressco gage which has historically exhibited $18 \mathrm{in.} \mathrm{of} \mathrm{runoff.}$

Eighteen pumping centers and a conservation pool in the flood detention area. - The effects of a simulated conservation pool in the flood detention area on the potentiometric surface of the Floridan aquifer with a $274 \mathrm{Mgal} / \mathrm{d}$ withdrawal is shown in figure 35 . The maximum drawdown was reduced from 38 to $32 \mathrm{ft}$ and the average drawdown for the model area was reduced from 6 to $5 \mathrm{ft}$. The pumping was simulated by the same 18-pumping node arrangement described previously. The conservation pool was simulated by making the head in the sand aquifer (in the conservation pool area) equal to $100 \mathrm{ft}$ above mean sea level where it was previously below $100 \mathrm{ft}$. The $1-\mathrm{ft}$ average reduction in drawdown due to the conservation pool does not accurately reflect its significant local effects. Comparison of figures 32 and 35 show no change in the potentiometric surface in the eastern part of the swamp or roughly that area upgradient from the 90-ft contour. However, there is a 5- to 10- $\mathrm{ft}$ reduction in drawdown over a large area west of the flood detention area. 


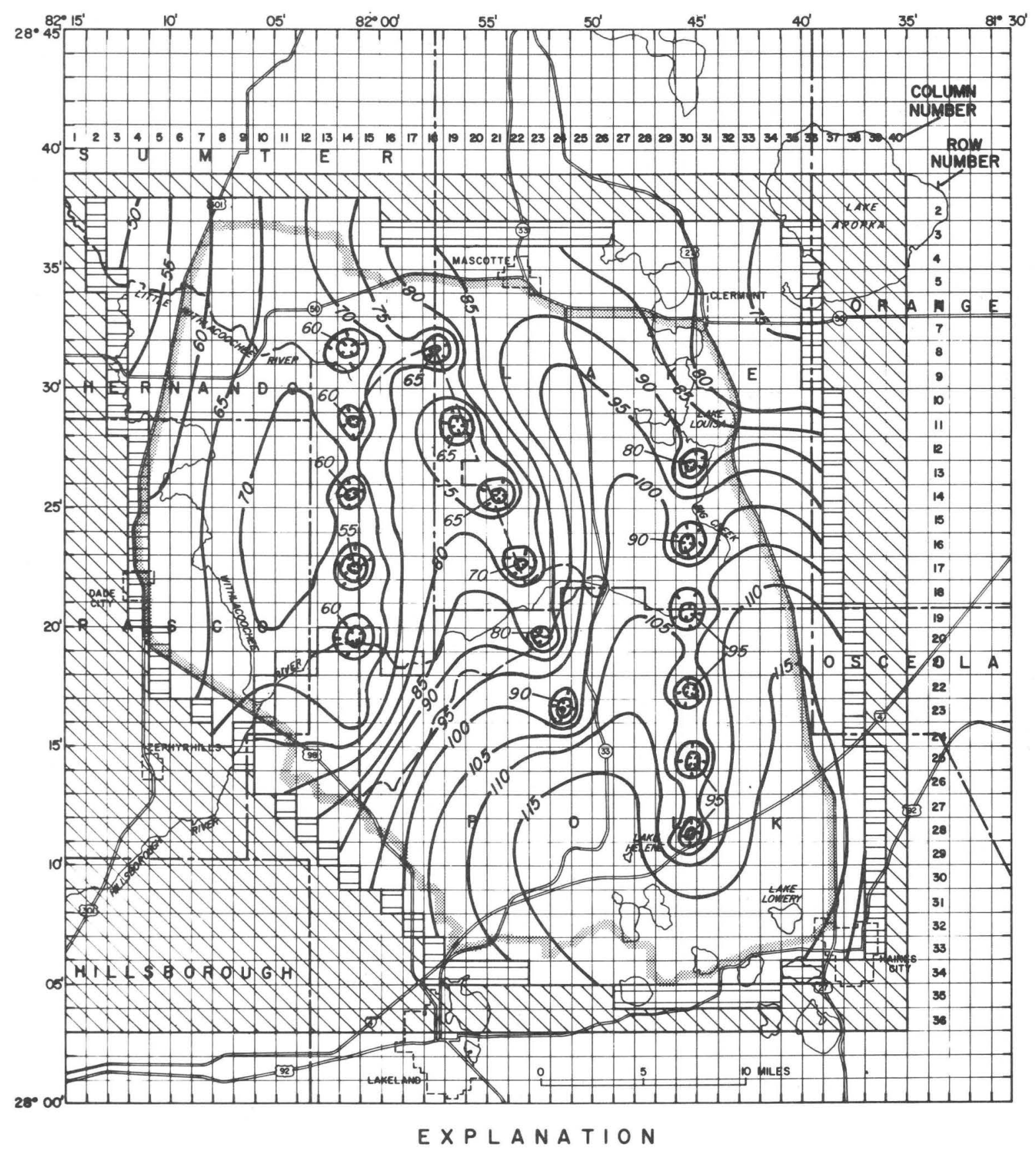

BOUNDARY OF GREEN SWAMP AREA

7 NO-FLOW

- 90- SIMULATED POTENTIOMETRIC CONTOUR. CONTOUR NODE INTERVAL 5 FEET. DATUM IS MEAN SEA LEVEL.

- FLOOO DETENTION AREA PROPOSED BY SOUTHWEST FLORIOA WATER MANAGEMENT DISTRICT

rigure 32.--Simulated effects of pumping about 274 million gallons per day on the potentiometric surface of the Floridan aquifer 

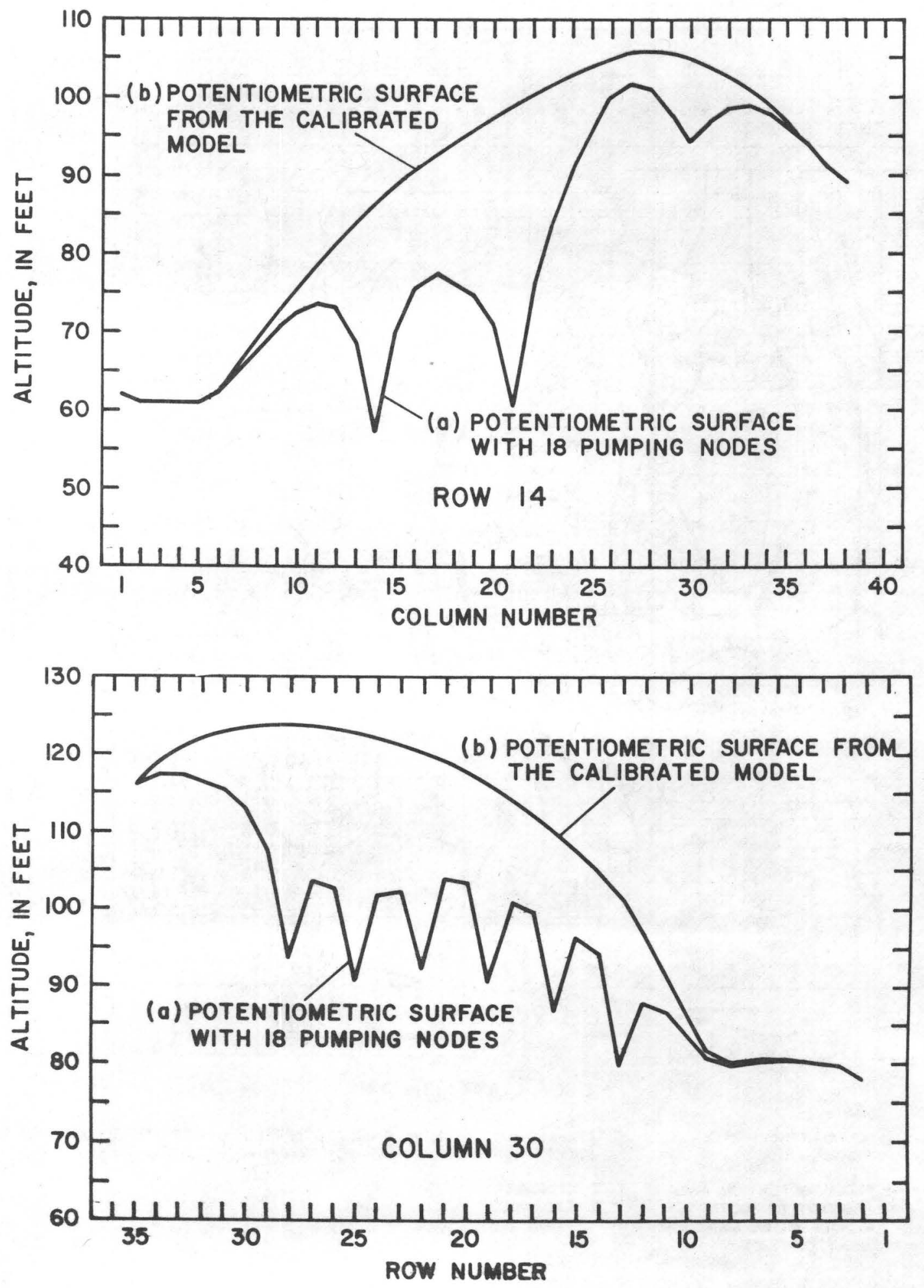

Figure 33.--Simulated potentiometric surfaces of the Floridan aquifer: (a) with 18 pumping centers, (b) without pumpage 


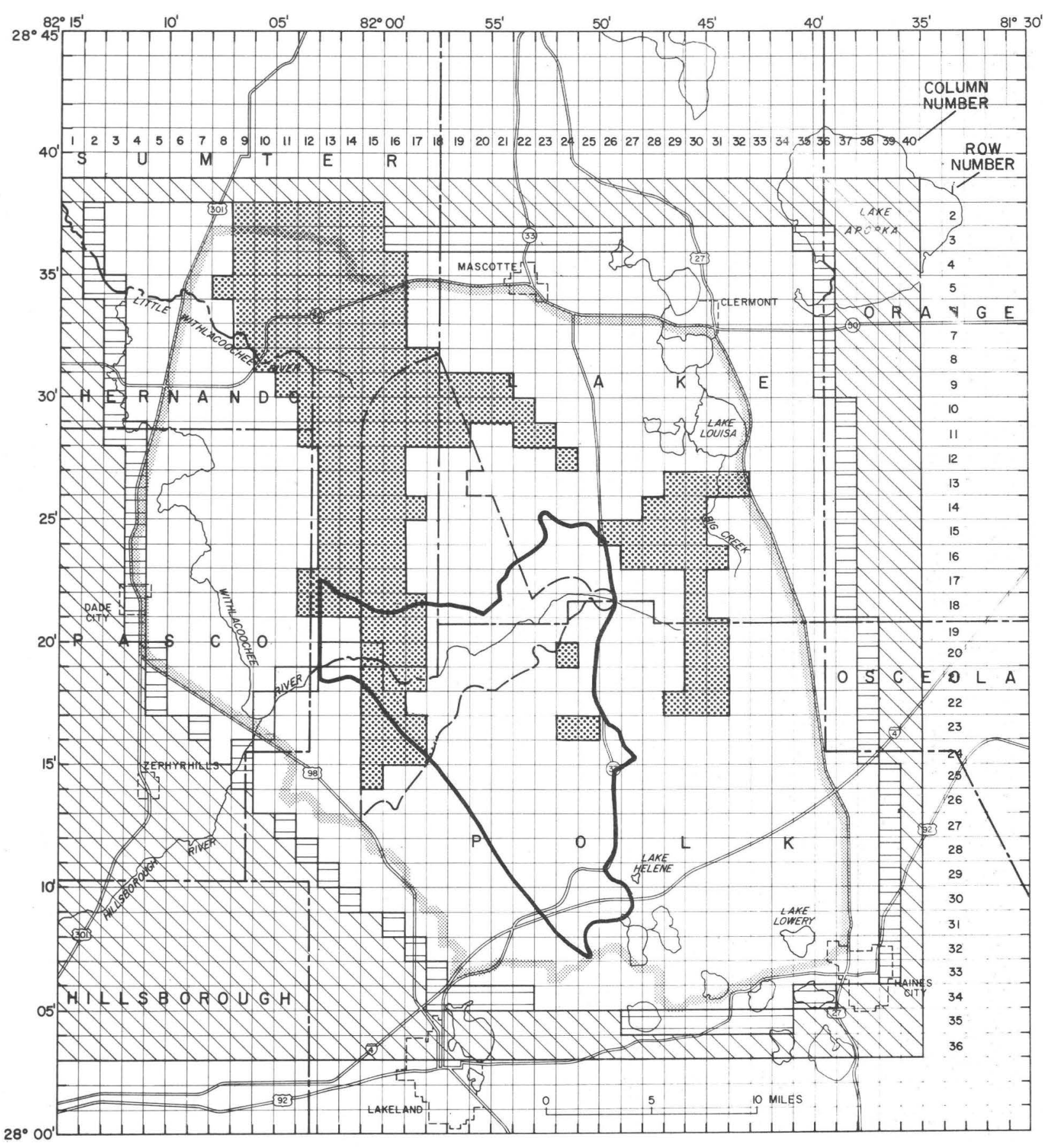

EXPLANATION

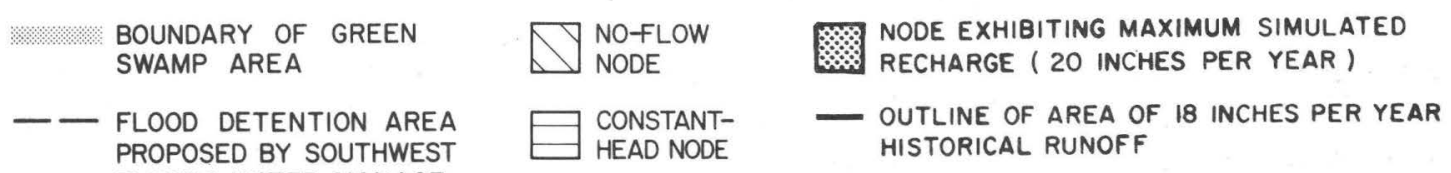
FLORIDA WATER MANAGEMENT DISTRICT

Figure 34.--Model nodes that exhibited maximum simulated recharge (20 inches per year) with pumpage of 274 million gallons per day 


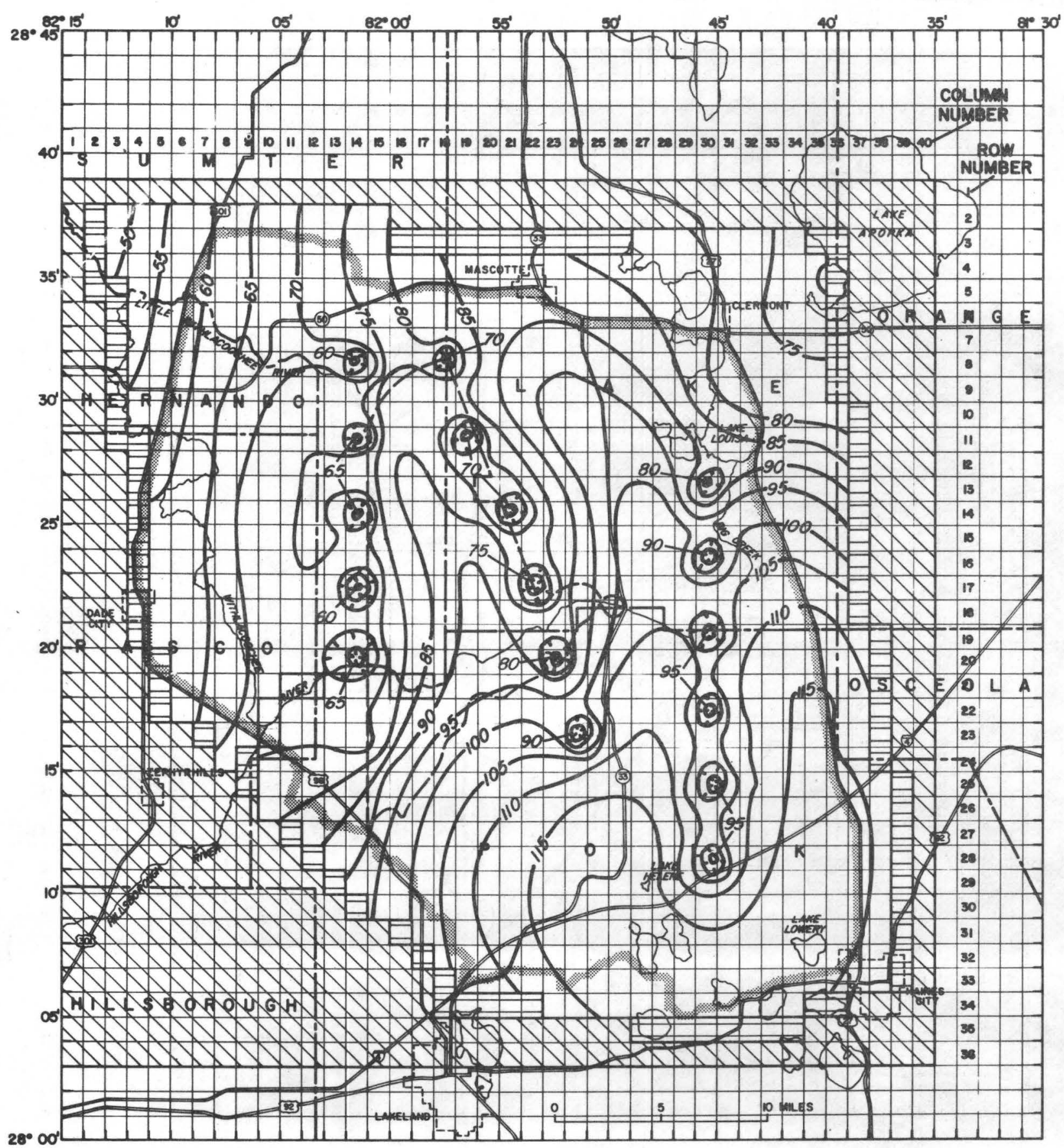

\section{EXPLANATION}

BOUNDARY OF GREEN SWAMP AREA

- - FLOOD DETENTION AREA PROPOSED BY SOUTHWEST FLORIDA WATER MANAGEMENT DISTRICT NOFLOW
MOOE

Figure 35.--Simulated effects of pumping about 274 million gallons per day on the potentiometric surface with a conservation pool in the flood detention area 
An increase in ground-water outflow of about 3 percent with a corresponding increase in ground-water recharge can be attributed to the conservation pool in the flood detention area (table 5).

Uniform changes in hydraulic coefficients.--The error associated with the estimated values of the two hydraulic coefficients, aquifer transmissivity and upper confining bed hydraulic conductivity, is unknown and there are no standard methods for evaluating this error or its effects on the results from the prototype. The best approach for this investigation appeared to be a demonstration of the effects of a uniform increase and decrease in the values of these two coefficients. The effects of a 25 percent increase and a 25 percent decrease in both the aquifer transmissivity and the upper confining bed hydraulic conductivity are shown in figure 36 under the simulated pumping stress of 18 pumping nodes described previously.

The prototype is more sensitive to the estimated values of upper confining bed hydraulic conductivity than to aquifer transmissivity. If the transmissivity was underestimated by as much as 25 percent in the prototype, then the general increase in the potentiometric surface would be only a few feet and averages less than one-half $\mathrm{ft}$ for the entire model area. However, if the upper confining bed hydraulic conductivity was overestimated by as much as 25 percent, then there would be large areas where the potentiometric surface would be as much as $10 \mathrm{ft}$ lower than estimated by the prototype and would average almost $4 \mathrm{ft}$ more for the entire model area.

The implications of the above relative to future data collection effort are that priority should be given to improving the estimates of upper confining bed hydraulic conductivity.

Boundary evaluation.--Confidence in a model subjected to pumpage can be assured if drawdown at no-flow boundaries is small and if outflow is not significantly decreased (or inflow is not significantly increased) at constant-head nodes relative to the non-pumped calibrated mode1. Drawdown at no-flow boundaries in the model with 18 pumping centers reaches a maximum at the northern boundary east of U.S. Highway 301 where it ranges from 3 to $5 \mathrm{ft}$. The horizontal extent of drawdown in this area is large because of the low value of hydraulic conductivity of the confining bed (fig. 27). Drawdown at all other no-flow boundaries in this model run and in the other three model runs is $2 \mathrm{ft}$ or less. The model with 18 pumping centers exhibited a 23 percent decline in total outflow to constant-head nodes relative to the nonpumped calibrated model. This decline was 20 percent for the model with 18 pumping centers, and 3 percent for the model with 6 pumping centers (table 5). Table 5 also shows that the increase in total inflow from constant-head nodes was very small relative to the non-pumped calibrated mode1. Drawdown at no-flow boundaries and flow change at constant-head nodes was small enough that the technical veracity of the model under pumping stress is considered good. 

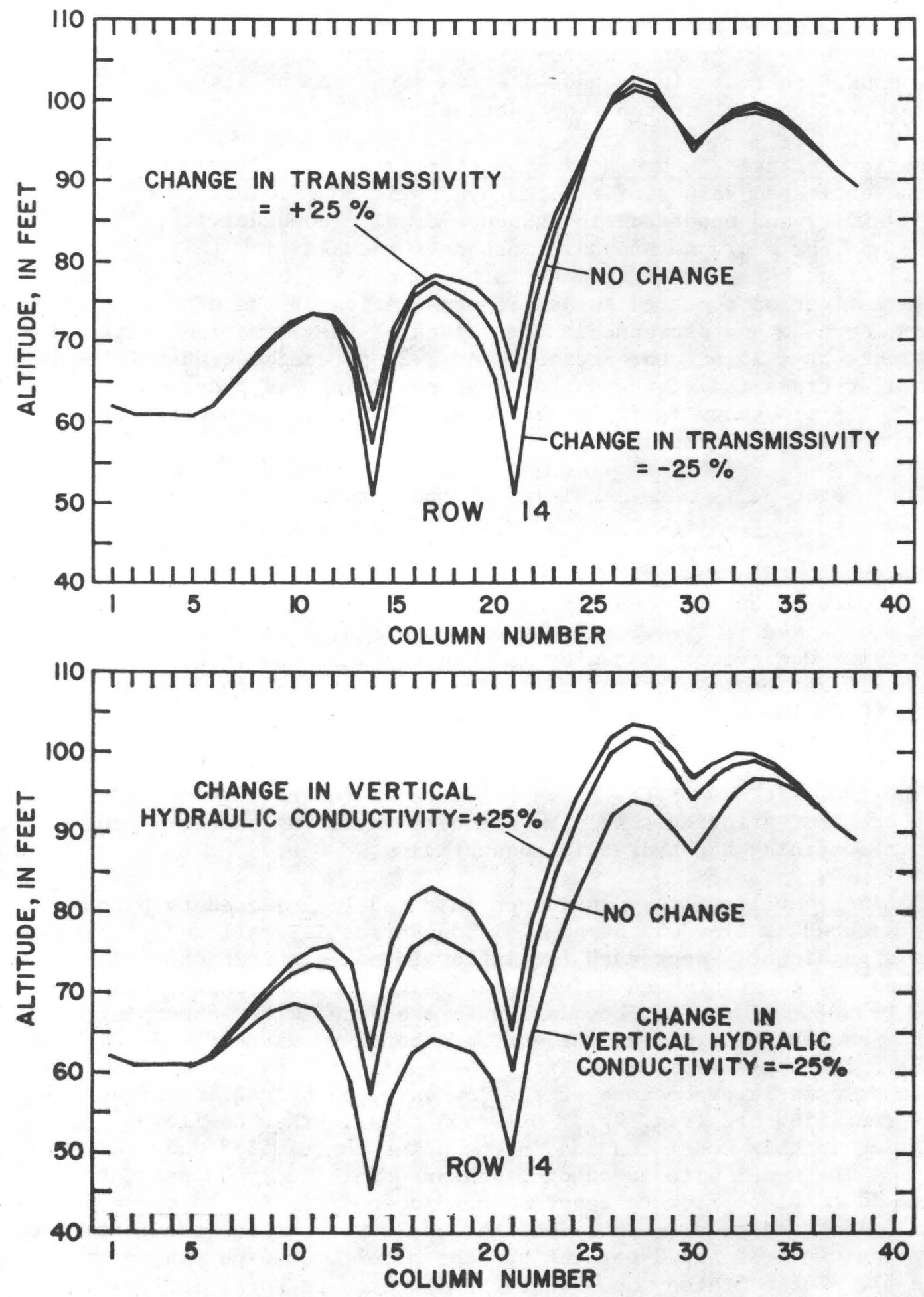

Figure 36.--Simulated potentiometric surface of the Floridan aquifer showing sensitivity of the prototype to a uniform increase and decrease in aquifer transmissivity and vertical hydraulic conductivity of the upper confining bed 
Pumping the Floridan aquifer will have significant effect on the potentiometric surface of the near-surface sand aquifer. An increase in the range of annual water-level fluctuations in the sand aquifer will occur if this aquifer functions successfully as a storage reservoir for water diverted from runoff or evapotranspiration.

The magnitude of the changes in the potentiometric surface of the sand aquifer can be indicated from the examination of three factors: (1) the vertical head gradient across the confining bed separating the sand aquifer from the Floridan aquifer; (2) the vertical hydraulic conductivity of this confining bed; and (3) the specific yield of the sand aquifer.

The vertical head gradient across the upper confining bed of the Floridan aquifer will be increased by the pumpage from the Floridan aquifer and the volume of leakage from the sand aquifer will increase in proportion to the increase in gradient until the potentiometric surface of the Floridan aquifer falls to the bottom of the upper confining bed. The maximum gradient for inducing leakage will exist when the sand aquifer is saturated to land surface and the potentiometric surface of the Floridan aquifer is drawn down to the bottom of the upper confining bed. This condition can exist in the western part of the Green Swamp at least on an annual basis when the volume of pumpage from the Floridan aquifer is equal to that simulated with the 18 pumping centers.

The time required to dewater the sand aquifer from an initial condition of maximum vertical gradient is shown by figure 37 for various values of confining bed hydraulic conductivity. These theoretical curves were developed with the same basic two-dimensional finite-difference ground-water flow model used to simulate pumping from the Floridan aquifer. A small (about $2 \mathrm{mi}^{2}$ ) areal prototype shown schematically in figure 37 was used to simulate the dewatering of the sand aquifer under the following conditions: (1) the aquifer is homogeneous, isotropic, $20 \mathrm{ft}$ thick and has a specific yield of 10 percent; (2) there is no lateral inflow or recharge; (3) initially the aquifer is fully satureated; (4) the confining bed is $10 \mathrm{ft}$ thick and contributes no water from storage; and (5) the head in the sub-adjacent aquifer is held constant at the elevation of the base of the confining bed.

An indication of the magnitude of drawdown in the sand aquifer for different areas in the Green Swamp can be interpreted from the curves in figure 37 if the limitations inherent in their development are recognized. For example, those areas in the Green Swamp, where the confining beds have values of vertical hydraulic conductivity of $8.6 \times 10^{-5} \mathrm{ft} / \mathrm{d}$ or less (fig. 27), a drawdown of $1 \mathrm{ft}$ or less (5 percent dewatered) will occur after a 1-yr period of no recharge. Since recharge 


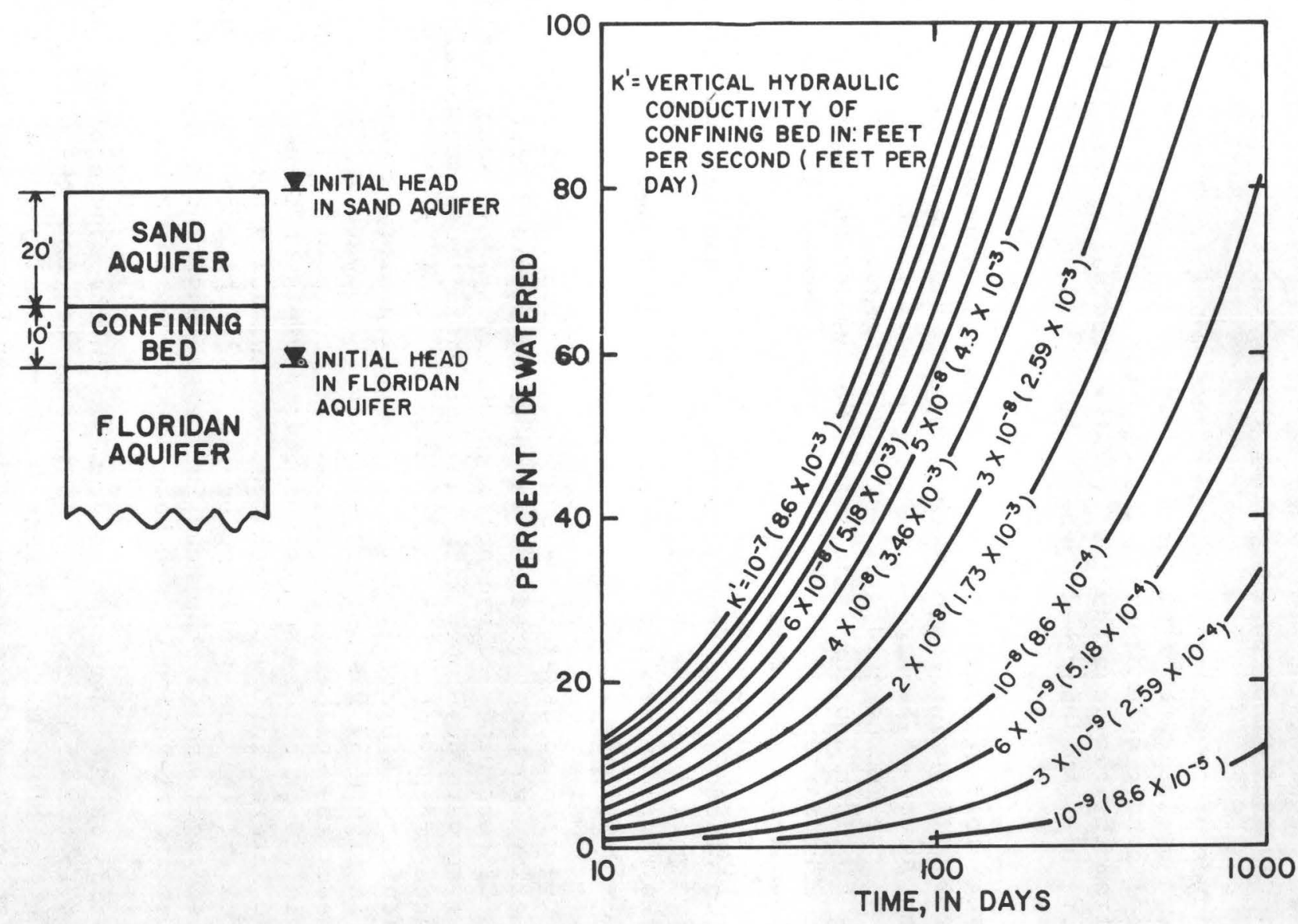

Figure 37.--Simulated time required to dewater the sand aquifer for various values of confining bed hydraulic conductivity with a simulated head condition of maximum vertical gradient and no recharge, assuming a specific yield of 10 percent for the sand aquifer 
to the sand aquifer from precipitation can be expected to occur long before 365 days have lapsed, a small drawdown can be expected in these areas under the most severe conditions of deficient precipitation which have been observed in the Green Swamp area or of maximum drawdown in the Floridan aquifer. At the other end of the range of confining bed characteristics considerably more drawdown will occur in less time. Five ft of drawdown (25 percent) is expected after about 45 days without recharge for those areas shown in figure 27 with values of vertical hydraulic conductivity of $4.3 \times 10^{-3} \mathrm{ft} / \mathrm{d}$.

Although these examples apply strictly to those areas where the sand aquifer is $20 \mathrm{ft}$ thick and the confining bed is $10 \mathrm{ft}$ thick, the drawdowns and times are correct for any area where the following conditions are met: (1) the confining bed characteristics are as defined in the examples and figure 37; (2) the vertical gradient across the confining bed is $30 \mathrm{ft}$; and (3) the sand aquifer is equal to or greater than $20 \mathrm{ft}$ thick.

The critical areas relative to drawdown in the sand aquifer and the pumping of $274 \mathrm{Mgal} / \mathrm{d}$ from the Floridan aquifer are in the western part of the Green Swamp where the sand aquifer is less than about $16.5 \mathrm{ft}$ thick (fig. 13). In much of this area more water will have to be recharged than is required for an annual cycle of dewatering the aquifer with only one complete recharging. For example, a sand aquifer thickness of $8.3 \mathrm{ft}$ could supply $20 \mathrm{in}$. of water on an annual basis if it were dewatered and fully recharged twice during the year. This assumes that all the water in the sand aquifer leaks to the Floridan aquifer.

The volume of water which can be stored in the sand aquifer may be critical in the western part of the Green Swamp where the sand aquifer is less than about $16.5 \mathrm{ft}$ thick. The specific yield of only 10 percent assumed in this analysis would result in complete dewatering of the sand aquifer if the leakage limit of $20 \mathrm{in./yr}$ is achieved in these areas. However, if the specific yield is 20 percent only about $8.3 \mathrm{ft}$ of the sand aquifer would have to be dewatered to produce the $20 \mathrm{in./yr.}$

Available storage capacity must be increased in the upper part of the near-surface sand aquifer if a large quantity of water which currently leaves the area as surface runoff or evapotranspiration is to be diverted to the Floridan aquifer. This can be accomplished by pumping the Floridan aquifer if the sand aquifer is homogeneous and isotropic. A homogeneous and isotropic condition means that any increase in vertical gradient at the top of the upper confining bed will be transmitted uniformly upward through the sand aquifer with a resultant dewatering of the uppermost part of that aquifer. 
Loca11y, available storage capacity may not be adequate during periods of surplus water if the sand aquifer is inhomogeneous and anisotropic. A condition of inhomogeneity would result in different volumes of storage capacity per foot of drawdown from site to site. The length of time required for this storage capacity to devleop would also vary from site to site. An anisotropic condition could prevent any significant increased dewatering in the uppermost portion of the sand aquifer.

Drawdown in the sand aquifer, induced by pumping the Floridan aquifer at a south Lake County site within the Green Swamp, indicates that dewatering can be induced in the upper portion of the sand aquifer. The drawdown at two depths within the sand aquifer was almost equal at three of the four observation points. At the fourth observation point a $0.8-\mathrm{ft}$ lower water level was observed in the well finished at $31 \mathrm{ft}$ below land surface than in the well finished at 15 ft below land surface. This head drop developed after about 30 minutes of pumping and was maintained until the end of the test 5 days later.

Drawdown in the sand aquifer will be significant in areas of maximum recharge (fig. 34). In order that this drawdown can be evaluated more accurately in the future, a multilayer analysis may be necessary. This type of analysis would also aid in determining the best distribution of pumpage.

\section{Runoff and Evapotranspiration}

A reduction in the average long-term runoff from the entire area of about 4.5 in. can be expected with long-term ground-water withdrawals of $274 \mathrm{Mgal} / \mathrm{d}$ assuming no capture of evapotranspiration. Favorable conditions for recharging the sand aquifer should occur on an annual basis. Typically, available storage in the sand aquifer will be at a maximum just prior to the beginning of the wet season in June. Over 95 percent of the needed recharge is available in the 5-month period beginning in June if only one-half of the runoff is diverted to ground-water recharge.

It is doubtful that any significant change in evapotranspiration will occur because maximum runoff and maximum evapotranspiration occur simultaneously. Moreover, the minimum uncertainty of 15 percent associated with the best estimates of evapotranspiration (Lee, 1970, p. 1330), about 6 in. for this analysis, is almost equal to the total water diverted to produce the $274 \mathrm{Mgal} / \mathrm{d}$. 
A 1ong-term water supply is available from the Green Swamp area. It appears possible to divert as much as $274 \mathrm{Mgal} / \mathrm{d}$ from ground-water outflow and surface runoff by pumping the Floridan aquifer.

Estimates of principal water budget items are (1) inflow, 52.10 in. of rainfall and less than one-half in. of ground-water inflow and (2) outflow, 10 in. of surface runoff, 2 in. of ground-water outflow, and 40 in. of evapotranspiration. The development of water supplies in the Green Swamp area would divert water from one or more of the three natural outflows. It appears that some ground-water outflow and surface runoff can be diverted by pumping from the Floridan aquifer. Diversion of a significant quantity of water from evapotranspiration does not appear as promising in the Green Swamp as diversion of either runoff or groundwater outflow.

The potential value of the sand aquifer lies in its overall large storage capacity, rather than its potential for supplying water directly to pumping wells. The Floridan aquifer, on the other hand, has a potential for supplying large quantities of water because of its high transmissivity and because recharge to it from the overlying sand aquifer can be increased by pumping the Floridan. It may be possible to increase the recharge of the Floridan aquifer to $20 \mathrm{in./yr}$ over some large areas by pumping from the aquifer.

The effects of large-scale pumping from the Floridan aquifer was evaluated using a steady-state finite-difference ground-water flow model. The average simulated drawdown in the modeled area was $2 \mathrm{ft}$ for a withdrawal rate of $91 \mathrm{Mgal} / \mathrm{d}$ from 6 pumping centers, $4 \mathrm{ft}$ for a withdrawal rate of $183 \mathrm{Mgal} / \mathrm{d}$ from 12 pumping centers, and $6 \mathrm{ft}$ for a withdrawal rate of $274 \mathrm{Mgal} / \mathrm{d}$ from 18 pumping centers. The $274 \mathrm{Mgal} / \mathrm{d}$ pumpage figure is equivalent to the estimated natural ground-water outflow plus about 45 percent of the runoff from the Green Swamp, although the relative percentages of ground-water diversion and runoff diversion are dependent upon the quantity and distribution of simulated withdrawa1.

Future data-collection efforts should give priority to improving estimates of vertical hydraulic conductivity of the confining layer; the flow model was more sensitive to changes in the vertical hydraulic conductivity of the confining layer than it was to changes in aquifer transmissivity or the position of the potentiometric surface of the sand aquifer. Also, a multilayer simulation analysis is necessary to predict more accurately the drawdown in the Floridan aquifer, the drawdown in the sand aquifer, and the best distribuiton of future pumpage for maximum feasible diversion. 


\section{REFERENCES}

Cherry, R. N., Stewart, J. W., and Mann, J. A., 1970, General hydrology of the middle gulf area, Florida: Florida Department of Natural Resources, Bureau of Geology Report Investigations 56, 96 p.

Cooley, R. L., 1977, A method of estimating parameters and assessing reliability of models of steady-state ground-water flow theory and numerical properties: Water Resources Research 13(2): 318-324.

Cooper, H. H., Jr., Kenner, W. E., Brown, Eugene, 1953, Ground water in central and northern Florida: Florida Geological Survey Report Investigations $10,37 \mathrm{p}$.

Daniel, J. F., 1976, Estimating groundwater evapotranspiration from streamflow records: Water Resources Research 12(3): 360-364.

Grubb, H. F., 1977, Potential for downward leakage to the Floridan aquifer, Green Swamp area, central Florida: U.S. Geological Survey Water Resources Investigations 77-71, Map.

Grubb, H. F., Chappelear, J. W., and Miller, J. A., 1978, Lithologic and borehole geophysical data, Green Swamp area, Florida:

U.S. Geological Survey Water Resources Investigations 78-574, $270 \mathrm{p}$.

Healy, H. G., 1962, Piezometric surface and areas of artesian flow of the Floridan aquifer in Florida, July 6-17, 1961: Florida Geological Survey Map Series No. 4.

Hibbert, A. R., 1969, Water yield changes after converting a forested catchment to grass: Water Resources Research 5(3): 634-640.

1971, Increases in streamflow after converting chaparral to grass: Water Resources Research 7(1): 71-80.

Klein, Howard, 1971, Depth to base of potable water in the Floridan aquifer: Florida Department of Natural Resources, Bureau of Geology Map Series No. 42, 1 sheet.

Knochenmus, D. D., and Hughes, G. H., 1976, Hydrology of Lake County, Florida: U.S. Geological Survey Water Resources Investigations 76-72, $100 \mathrm{p}$.

Lee, Richard, 1970, Theoretical estimates versus forest water yield: Water Resources Research 6(5): 1327-1334.

Matson, G. C., and Sanford, Samuel, 1913, Geology and ground waters of Florida: U.S. Geological Survey Water-Supply Paper 319, 445 p. 
McQueen, I. S., and Miller, R. F., 1972, Soil-moisture and energy relationships associated with riparian vegetation near San Carlos, Arizona: U.S. Geological Survey Professional Paper 655-E, 51 p.

Pinder, G. F., and Bredehoeft, J. D., 1968, Application of the digital computer for aquifer evaluation: Water Resources Research, v. 4, p. 1069-1093.

Pride, R. W., Meyer, F. W., and Cherry, R. N., 1961, Interim report on the hydrologic features of the Green Swamp area in central

Florida: Florida Geological Survey Information Circular 26, 96 p.

1966, Hydrology of Green Swamp area in central Florida: Florida Geological Survey Report Investigations 42, 137 p.

Rutledge, A. T., and Grubb, H. F., 1978, Hydrogeologic maps of a flood detention area proposed by Southwest Florida Water Management District, Green Swamp Area, Florida: U.S. Geological Survey OpenFile Report 78-460, Map.

Ryder, P. D., Laughlin, C. P., and Mills, L. R., 1977, Potentiometric surface of Floridan aquifer Southwest Florida Water Management District and adjacent areas: U.S. Geological Survey Open-File Report 77-552, Map.

Schneider, W. J., and Ayer, G. R., 1961, Effect of reforestation on streamflow in central New York: U.S. Geological Survey Water Supply Paper 1602, 61 p.

Stewart, H. G., Jr., 1966, Ground-water resources of Polk County: Florida Geological Survey Report Investigations 44, 170 p.

Stewart, J. W., Mills, L. R., Knochenmus, D. D., and Faulkner, G. L., 1971, Potentiometric surface and areas of artesian flow, May 1969, and change of potentiometric surface 1964 to 1969 , Floridan aquifer, Southwest Florida Water Management District, Florida: U.S. Geologica1 Survey Hydrologic Investigations Atlas HA-440, 1 sheet.

Stringfield, V. T., 1936, Artesian water in the Florida peninsula: U.S. Geological Survey Water Supply Paper 773-C, 195 p.

Swank, W. T., and Miner, N. H., 1968, Conversion of hardwood-covered watersheds to white pine reduces water yield: Water Resources Research 4(5): 947-954.

Thornthwaite, C. W., 1944, Report of the committee on transpiration and evaporation, 1943-44: Trans., America Geophysical Union 25: 686-693. 
Thornthwaite, C. W., and Mather, J. R., 1957, Instructions and tables for computing potential evapotranspiration and the water balance: Drexel Institute of Technology, Publications in C1imatology, 10(3): 185-311.

Unklesbay, A. G., 1944, Ground water conditions in orlando and vicinity: Florida Geological Survey Report Investigations 5, 61 p.

U.S. Geological Survey, 1931, Surface water supply of the United States, 1931: Part 2, South Atlantic S1ope and Eastern Gulf of Mexico basin: U.S. Geologica1 Survey Water Supply Paper 712, 233 p.

Wilson, W. E., 1977, Simulated changes in ground-water levels resulting from proposed phosphate mining, west-central Florida--preliminary results: U.S. Geological Survey Open-File Report 77-887, 46 p.

*U.S. GOVERNMENT PRINTING OFFICE: 1979-641-641/6256. Region 4. 